\author{
UNIVERSIDADE DE SÃO PAULO \\ FFCLRP - DEPARTAMENTO DE BIOLOGIA \\ PROGRAMA DE PÓS-GRADUAÇÃO EM BIOLOGIA COMPARADA
}

\title{
A Estética e o Ensino de Biologia: nas trilhas de Saint-Hilare
}

Gabriela Cristina Sganzerla Iglesias

Dissertação apresentada à Faculdade de Filosofia, Ciências e Letras de Ribeirão Preto da USP, como parte das exigências para obtenção do título de Mestre em Ciências, Área: Biologia Comparada

RIBEIRÃO PRETO - SP 
GABRIELA CRISTINA SGANZERLA IGLESIAS

A Estética e o Ensino de Biologia: nas trilhas de Saint-Hilare

Versão corrigida

Dissertação apresentada à Faculdade de Filosofia, Ciências e Letras de Ribeirão Preto da USP, para obtenção do título de Mestre em Ciências.

Área de concentração: Biologia Comparada

Orientadora: Profa. Dra. Fernanda da Rocha Brando

Ribeirão Preto 
Autorizo a reprodução e divulgação total ou parcial deste trabalho, por qualquer meio convencional ou eletrônico, para fins de estudo e pesquisa, desde que citada a fonte.

\author{
Catalogação da \\ Publicação Serviço de \\ Documentação
}

Faculdade de Filosofia, Ciências e Letras de Ribeirão

Preto Universidade de São Paulo

Iglesias, Gabriela Cristina Sganzerla

A Estética e o Ensino de Biologia: nas trilhas de Saint-Hilare, 2017. 103p.: il.; $30 \mathrm{~cm}$

Dissertação de Mestrado, apresentada à Faculdade de Filosofia, Ciências e Letras de Ribeirão Preto/USP. Área de concentração: Biologia Comparada.

Orientadora: Brando, Fernanda da Rocha.

1. Filosofia Estética 2. Charles Sanders Peirce 3. Aldo Leopold 4. Ensino de Ciências 5. Naturalistas viajantes 6. Serra da Canastra 
Nome: IGLESIAS. Gabriela Cristina Sganzerla Iglesias

Título: A Estética e o Ensino de Biologia: nas trilhas de Saint Hilare

Dissertação apresentada à Faculdade de Filosofia, Ciências e Letras de Ribeirão Preto da USP, para obtenção do título de Mestre em Ciências, Área: Biologia Comparada

Aprovada em:

Banca Examinadora

Prof.(a) Dr.(a): Instituição:

Julgamento: Assinatura:

Prof.(a) Dr.(a): Instituição:

Julgamento: Assinatura:

Prof.(a) Dr.(a): Instituição:

Julgamento: Assinatura: 


\section{AGRADECIMENTOS}

À minha família, minha base e meu suporte desde sempre. Obrigada por investirem tanto nos meus estudos.

Ao Gabriel, meu companheiro da vida e de aventuras, por ser meu melhor amigo, amor e conselheiro.

À orientadora Fernanda da Rocha Brando por todo o aprendizado, apoio e amizade.

À todos os componentes do Laboratório de Epistemologia e Didática da Biologia pela ajuda nas ideias do trabalho e nas viagens para a Serra da Canastra, em especial Giselle, Bianca, Silvia e Paula.

À Universidade de São Paulo, à Faculdade de Filosofia, Ciências e Letras de Ribeirãoo Preto, e ao Programa de Pós graduação em Biologia Comparada pela ótima formação que me proporcionaram.

À CAPES pela concessão de bolsa mestrado, tornando possível o desenvolvimento desta pesquisa.

Ao querido Ulisses Florencio Seabra, amável morador de Campinópolis que contribuiu grandemente para a pesquisa.

À minha querida irmã amiga Jéssika Leão que me acolheu em sua casa com tanto carinho durante as minhas viagens à Ribeirão Preto.

Ao professor Milton Groppo pela ajuda e por ter permitido que participasse da viagem de campo de sua disciplina.

A todos os moradores da Serra da Canastra que tive a oportunidade de conversar e que foram tão gentis e dispostos a ajudar.

E, principalmente, ao Ser Superior que guia todos meus passos e norteia minha vida. 


\section{Já é tempo que haja tempo \\ (Il est temps qu'il soit temps) \\ Paul Celan, extraído de Corona, Poemas.}

Há urgência, e isso a todo instante. Já é tempo que haja tempo não significa em absoluto que precisamos nos apressar, nos lançar impetuosamente (de corpo e alma) no rebuliço do tempo. É, todavia, a uma tal velocidade, até a uma pulverização do tempo que sem cessar nos convidam, nos incitam. O culto da velocidade é celebrado com uma frenesie crescente em nossas sociedades, em ligação com outros Bezerros de ouro que são a performance, a glória, a consumação, a rentabilidade.

Já é tempo que haja tempo. A urgência é outra, e tal que reenvia de fato a isso que pode parecer incompativel com ela: a paciência. Para que advenha autenticamente o tempo é necessário começar por parar, quer dizer, surpreender-se diante disso que a força passiva do hábito nos fez crer evidente, portanto, por atingir toda evidência da inevidência. Então, a mais ordinária das coisas pode se revelar extraordinária porque a imaterial presença do tempo se deixa adivinhar, tão tênue como um sopro, na espessura de toda matéria, e toda matéria, mesmo mineral, toma pouco a pouco uma textura de carne. Essa carnação das coisas é tão perturbadora que o pensamento nela se encontra derrotado, e, avançando apenas às cegas, ele se faz tátil. O pensamento nada sabe, ele roça a impalpável pele do mundo sob a qual ele sente bater o pulso do tempo.

Parar, surpreender-se, pacientar, aprender a contemplar o mundo com um olhar tátil, piscar lentamente as pálpebras face ao visível, acolher em seu ouvido o sopro do silêncio - tal é a urgência. É tempo que nosso pensamento se aventure como humilde vagabundo no mistério do tempo... É tempo de desnudar o tempo dos ouros e dos cobres com os quais o trevestimos, e de nos vestirmos com sua absoluta nudez, com esse nada que sem cessar murmura e brilha no grão de nossa pele voltada às rugas, à poeira, à desaparição. 


\section{RESUMO}

IGLESIAS, G. C. S. A Estética e o Ensino de Biologia: nas trilhas de Saint-Hilare. 2017. 103p. Dissertação de Mestrado - Faculdade de Filosofia, Ciências e Letras de Ribeirão Preto, Universidade de São Paulo, Ribeirão Preto, 2017.

Esta pesquisa, inserida na linha de pesquisa "História, Filosofia e Ensino de Evolução e Ecologia", trata sobre a Estética, procurando verificar as possíveis contribuições desse referencial teórico para o estudo do meio em Biologia, nomeadamente para aulas de campo voltadas para o Ensino Superior em cursos de Ciências Biológicas. A Estética descrita por Charles Sanders Peirce (1839-1914), não limita-se somente ao entendimento da Estética como uma ciência do belo. A Estética peirceana possui um caráter mais abrangente, que reside na essência de qualquer objeto apreendido pela experiência; o admirável que desperta a atenção, seja o objeto considerado belo ou não pelas convenções. Nas ideias de Aldo Leopold (1887-1948), que tratam de uma Estética voltada para a conservação dos seres vivos, verifica-se um diálogo com a Teoria de Peirce por meio das cinco categorias da Estética da Conservação: os troféus, o isolamento na natureza, ar livre e mudança de panorama, percepção e sentido da administração cuidadosa. Considerando essas categorias, foi proposta uma sequência didática tendo a trilha realizada pelo naturalista Auguste de Saint-Hilaire (1779-1853) na Serra da Canastra (MG) como eixo norteador. A proposta com abordagem interdisciplinar favorece o desenvolvimento das aulas de campo a partir de elementos filosóficos e históricos, permitindo que os alunos revisitem os ambientes descritos por Saint-Hilaire de maneira mais motivadora e contextualizada.

Palavras-chave: Filosofia Estética, Charles Sanders Peirce, Aldo Leopold, Ensino de Ciências, Naturalistas viajantes, Serra da Canastra 


\begin{abstract}
IGLESIAS, G. C. S. Aesthetics and Biology teaching: on the trails of Saint-Hilare. 2017. 103p. Dissertação de Mestrado - Faculdade de Filosofia, Ciências e Letras de Ribeirão Preto, Universidade de São Paulo, Ribeirão Preto, 2017.

This proposal is inserted in the research line "History, Theory and Teaching of Comparative Biology" and will work with Aesthetics seeking to verify the possible contributions of this theoretical reference for the study of the environment in Biology, particularly in field classes focused on Higher Education in Biology Graduation. The Aesthetics, described by Charles Sanders Peirce (1839-1914), is not limited to a science of the beautiful. Aesthetics has a more comprehensive character and resides in the essence of any object apprehended in our experience that arouses our attention, be it considered beautiful or not by the conventions. It it something that we consider "admirable". We found in the ideas of Aldo Leopold (1887-1948), that deals with an Aesthetics focused on the conservation of living beings, a dialogue with Peirce's Theory. Leopold (1949) proposes five categories of Conservation Aesthetics: trophy, isolation, change of scene, perception and husbandry. Based on these categories it was proposed a Didactic Sequence having the trail made by the naturalist Auguste de SaintHilaire (1779-1853) in Serra da Canastra as a background. We chose to adopt an interdisciplinary approach, and while the students revisit the points visited by SaintHilaire, field classes are developed with the aim of investigating the environment as the naturalist himself did.
\end{abstract}

Keywords: Aesthetic philosophy, Charles Sanders Peirce, Aldo Leopold, Biology teaching, Naturalist travelers, Serra da Canastra. 


\section{LISTA DE FIGURAS}

Figura 1 - Esquema da configuração da Estética como parte da Filosofia. Fonte: adaptado de Santaella $(2000$, p. 12) ............................................. 11

Figura 2 - Retrato de Charles Sanders Peirce (1839-1914). Fonte: http://philweb.rlwclarke.net/History/Twentieth/Pragmatism/Peirce/Peirce.htm........12

Figura 3 - Collected Papers de Peirce, volumes I e II. A série de obras compreende cinco volumes no total. Fonte: https://book.douban.com/subject/4908720/.... 15

Figura 4 - Livro Estética: de Platão a Peirce de Santaella (1994), uma das principais obras utilizadas na pesquisa. Fonte: https://www.traca.com.br/livro/886454/esteticaplatao-peirce/.... 16

Figura 5 - Livro de Auguste de Saint-Hilaire (1779-1853) utilizado como base para o planejamento das aulas. Fonte: http://www.submarino.com.br/produto/5782757/livroviagem-as-nascentes-do-rio-sao-francisco.

Figura 6 - Esquema apresentando a arquitetura geral da pesquisa. .20

Figura 7 - Diagrama representando a organização esquemática da arquitetura filosófica de Charles Sanders Peirce. Fonte: adaptado de Santaella (1994). .25

Figura 8 - Livro de Aldo Leopold (1949) que trata da Estética da Conservação. Fonte: https://en.wikipedia.org/wiki/A_Sand_County_Almanac\#/media/File:Sand_county_alm anac.jpg) 40

Figura 9 - Retrato de Auguste de Saint-Hilaire (Augustin François César PROUVENSAL DE SAINT-HILAIRE). Fonte: https://commons.wikimedia.org/wiki/File:Auguste_de_Saint-Hilaire.................48

Figura 10 - Mapa de toda a rota de Saint-Hilaire à margem do Rio São Francisco. Fonte: (LICCARDO \& MENDES, 2001) .53

Figura 11 - Mapa original contendo o trajeto percorrido pelo naturalista em sua expedição pelo Brasil. Fonte: Herbário virtual A. de Saint-Hilaire 54

Figura 12 - Mapa da região da Serra da Canastra contendo os pontos da trilha realizada por Saint-Hilaire, e os locais relevantes à sequência didática. Fonte: autora. . .61

Figura 13 - Foto da antiga Fazenda João Dias. Fonte: autora .63 
Figura 14 - Foto da antiga casa do Felisberto. Fonte: autora. .64

Figura 15 - Foto frontal da cachoeira Casca D'anta na parte baixa. Fonte: autora.....65

Figura 16 - Foto da nascente simbólica do rio São Francisco. Fonte: autora.

Figura 17 - Foto da antiga capela de São Roque, denominada atualmente como Capela Velha. Fonte: arquivo de Antonio Francisco de Farias

Figura 18 - Foto da Capela Antiga e da nova matriz sendo construída. Fonte: arquivo de Antonio Francisco de Farias. .68

Figura 19 - Foto da atual Igreja Matriz de São Roque de Minas. Fonte: arquivo de Antonio Francisco de Farias.

Figura 20 - Fotos da canela-de-ema (Vellozia squamata) encontradas no Chapadão da Canastra. Fonte: autora. 70

Figura 21 - Imagem do herbário de A. de Saint-Hilaire: exemplar de Vellozia squamata. Data da coleta: 1816-1821. Fonte: Herbário virtual de A. de Saint-Hilaire..71

Figura 22 - Foto de espécie da família Euriocaulaceae encontrada no Chapadão da Canastra. Fonte: autora. .72

Figura 23 - Imagens de exemplares de Actinocephalus bongardii coletadas e descritas por Saint-Hilaire, pertencentes à família Eriocaulaceae. Data: 1816-1821. Local: Serra da Canastra. Fonte: Herbário virtual de A. de Saint-Hilaire .72

Figura 24 - Imagens de Curtia sp. coletadas e descritas por Saint-Hilaire, pertencentes à família Gentianaceae. Data: 1816-1821. Local: Serra da Canastra. Fonte: Herbário virtual de A. de Saint-Hilaire................................................... 73

Figura 25 - Lobeira encontrada no Chapadão da Serra da Canastra. Fonte: autora......74

Figura 26 - Imagem de Solanum lycocarpum coletada por Saint-Hilaire, pertencentes à família Solanaceae. Data: 1816-1821. Local: Prov. Minas Gerais. Fonte: Herbário virtual de A. de Saint-Hilaire.

Figura 27 - Esquema relacionando os dias da viagem de campo com as categorias de Aldo Lepold (1949).......................................................... 80

Figura 28 - Esquema geral da Sequência Didática completa........................86 


\section{LISTA DE QUADROS}

Quadro 1 - As etapas da pesquisa e suas descrições.

Quadro 2 - A Categorias de Leopold (1949). A seta representa que essas categorias aparecem de uma forma crescente em nível de profundidade, sendo a categoria 5 a que exige um nível de profundidade maior na relação estética com o meio...... .45

Quadro 3 - Aulas teóricas iniciais. .78 


\section{SUMÁRIO}

APRESENTAÇÃ

CAPÍTULO 1. O PENSAR E O SENTIR.......................................................................3

1.1. O Ensino, a impessoalidade, e a fragmentação do conhecimento.............................4

1.2. Em busca de uma Filosofia Estética ...................................................................

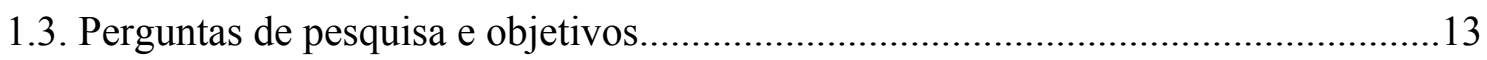

CAPÍTULO 2. METODOLOGIA........................................................................14

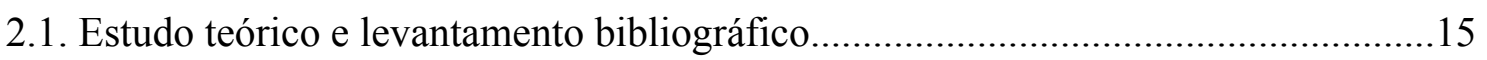

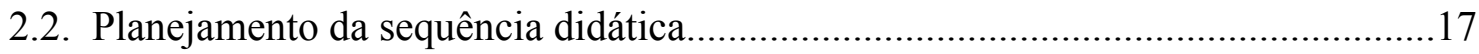

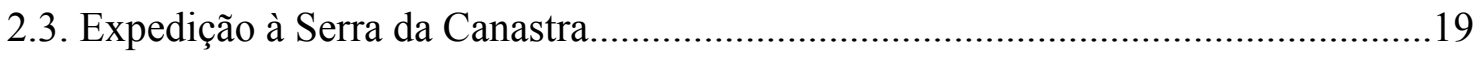

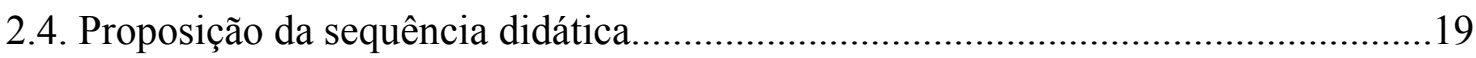

CAPÍtUlo 3. A ESTÉticA, A ÉTICA E A LÓGICA EM NOSSA RELAÇÃo

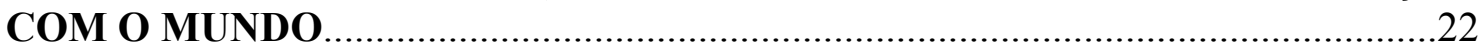

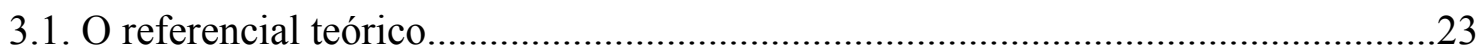

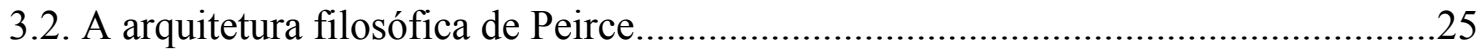

3.3. As Ciências Normativas e o crescimento em importância da Estética na Teoria de

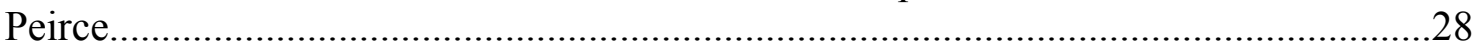

3.4. As dificuldades na definição da Estética e de seu ideal último.................................31

CAPÍTULO 4. O ENCANTAMENTO NO ENSINO....................................................35

4.1. A importância da Estética no Ensino de Ciências e Biologia.....................................36

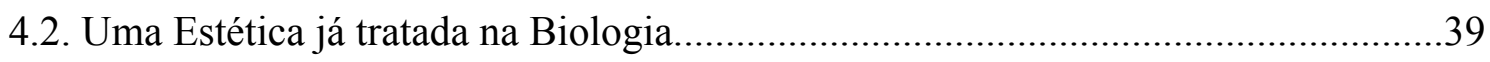

4.3. As ideias de Aldo Leopold sobre a Estética da Conservação e o diálogo com

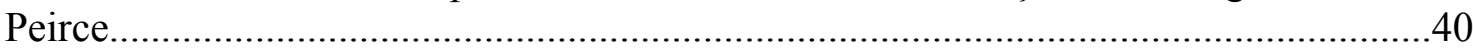

CAPÍTULO 5. NAS TRILHAS DE SAINT-HILAIRE..............................................46

5.1. Elaboração da sequência didática: nas trilhas de Saint-Hilaire...............................47 
5.2. Saint-Hilaire na Serra da Canastra

5.3. Resgatando a trilha de Saint-Hilaire na Serra da Canastra.

CAPÍTULO 6. A SEQUÊNCIA DIDÁTICA...............................................................76

CONSIDERAÇOES FINAIS....................................................................................87

REFERÊNCIAS BIBLIOGRÁFICAS..............................................................89

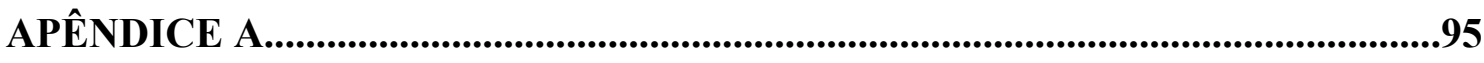

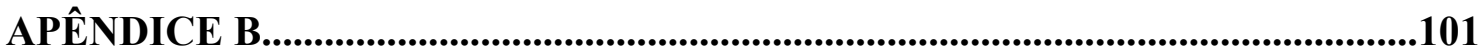




\section{APRESENTAÇÃO}

O desconhecido. O diferente. Sempre fui atraída pelo desconhecido, carregado de mistério. Desde sempre sentia-me motivada a buscar aquilo que me transcende, que vai além do terreno comum. Com o passar do tempo, pude notar que o cotidiano da minha vida não era capaz de sanar todo meu anseio por coisas novas. Minha experiência na vida não acompanhava a velocidade do meu desejo por conhecer mais, por trilhar caminhos distintos, por conhecer realidades alternativas. Foi assim, desde muito cedo, que encontrei minhas duas grande paixões: a leitura e a natureza. Nelas pude canalizar meu anseio pelo desconhecido e pelo diferente.

Antes de tudo, a minha primeira paixão surgiu em meio aos livros. Meu pai foi a primeira pessoa que me incentivou a desenvolver o gosto pela leitura, e em seguida, minha avó, uma amante dos livros, fez com que eu entendesse que nunca se está sozinho quando se tem um bom livro a ser lido. Assim, iniciei com livros infantis, aqueles sugeridos na escola, mas, com o tempo, esses livros não me saciavam mais. Passei a buscar livros diferentes, e a ler qualquer coisa que encontrasse à minha disposição, indo desde livros de viagem, literatura brasileira, auto-ajuda, biografias, até livros de marketing e liderança usados por meu pai em seu trabalho.

$\mathrm{Na}$ leitura pude viajar por diversos mundos sem sair de casa. Viajei para lugares nunca imaginados e para realidades inexistentes, mas que se fizeram existir em minha imaginação. Fiz das letras o meu ticket de viagem para onde quisesse, sendo cada livro um ambiente completamente inesperado a ser explorado, compartilhado por alguém como eu, mas, ao mesmo tempo, completamente diferente de mim. Dentre esses infindos mundos, encontrei o mundo natural. A natureza se revelou a mim como uma consequência da leitura. Nos livros encontrei fatos e curiosidades sobre os seres vivos em sua fascinante diversidade. Esse mundo curioso que surgiu nas letras, concretizou-se na observação enquanto realizava viagens com minha família para locais onde podíamos interagir com a natureza.

Quando tive a oportunidade de optar por uma carreira, após um tempo de indecisão, a óbvia escolha de estudar o fenômeno da vida em suas mais diversas formas foi tomada. Iniciei o curso de Ciências Biológicas na USP em Ribeirão Preto com grande entusiamo. Conhecer outros seres vivos e os ambientes onde vivem, e ter a noção de que todos compartilham da vida, mostrou-se cada vez mais encantador. Encontrei o mundo microscópico e o macroscópico de formas não imaginadas, e assim, pude me enxergar como parte da natureza em sua grande diversidade. Porém, com o passar do tempo, mediante inúmeras horas de atividades, aulas, provas e trabalhos comecei a notar todo o maravilhamento que possuía esvair-se a cada dia. $\mathrm{O}$ 
anseio por conhecer cada vez mais o mundo natural deixou de existir e tudo passou a ser enfadonho e mecânico. Por um período, grande parte da Biologia tornou-se para mim mera obrigação, mesmo que em alguns momentos o amor por essa área do conhecimento insistisse em permanecer. Até que o momento em que cheguei a me perguntar se realmente estava seguindo a carreira certa. Talvez meu amor pela natureza deveria ter sido deixado intocado em minha inocência de criança.

Todos os meus colegas de turma começaram a buscar laboratórios para desenvolver iniciação científica, e assim como todos, achei-me na obrigação de me enquadrar em algum local para não ser deixada para trás. Fiz diversas tentativas, mas nada parecia interessante. Porém, um dia conheci a professora Fernanda Brando ao ministrar uma de suas disciplinas. Nossas primeiras conversas foram um tanto confusas, já que, meu pensamento não conseguia acompanhar o turbilhão de ideias que surgiam das palavras da professora. Porém, desde o primeiro momento, o entusiasmo e o carinho trasmitido pelo olhar daquela mulher e sua abertura para investigar diferentes e desafiantes focos de pesquisa foi contagiante. Assim, sempre que me encontrava um tanto desanimada, sua motivação me inspirava.

Desenvolvi minha iniciação científica no Laboratório de Epistemologia e Didática da Biologia, onde pude discutir e compreender melhor a respeito da natureza da ciência, como essa é construída e desenvolvida. Dentre as inúmeras reuniões e discussões, no laboratório fui apresentada à Teoria de Peirce. Ao buscar entender melhor as ideias de Peirce encontrei uma visão de mundo da qual compartilhava, e que me permitia entender de forma diferente a minha relação com os objetos e fenômenos que me circundavam.

Pouco antes de me formar em Biologia, deparei-me com a parte da Teoria de Peirce que trata da importância da Estética em nossa relação com o mundo, e assim, pude compreender o que havia sido tão desmotivador em minha experiência como estudante de Biologia. A ciência havia sido apresentada a mim, em muitos momentos, como algo mecânico, sem cor e desinteressante, abafando o encanto que havia cultivado desde a infância.

Hoje, após um período de amadurecimento, resgatei minha paixão pelo mundo natural e pela leitura, e entendi que sem o encanto a busca pelo conhecimento pode ser vazia. Em consequência desses eventos que delimitaram minha formação e determinaram quem eu sou, fui motivada a desenvolver a pesquisa que será apresentada a seguir. 


\section{CAPÍTULO 1. \\ O PENSAR E O SENTIR}

" $A$ amorosidade, a afetividade, não enfraquecem em nada, primeiro, a seriedade de estudar e produzir; segundo, não obstaculizam em nada a responsabilidade política e social. Eu tenho vivido a minha vida amorosamente."

Paulo Freire 


\subsection{O Ensino, a impessoalidade, e a fragmentação do conhecimento}

A historiografia brasileira possui como uma de suas principais fontes de dados a literatura de viagens realizadas no século XIX. Os naturalistas viajantes, que estiveram no Brasil no século passado, desbravavam parte do país e deixavam seus relatos sob a forma de livros. A literatura de muitos deles têm sido usada não apenas como fonte de informações sobre o Brasil de nossos antepassados, mas também como inspiração para as grandes linhas interpretativas de nossa história (KURY, 2003).

Henry Walter Bates (1824-1892), nascido em Leicester na Inglaterra, foi um dos naturalistas que interessou-se profundamente pela floresta brasileira, principalmente a Floresta Amazônica. Ele realizou uma expedição ao Brasil juntamente com Alfred Russel Wallace (1823-1913) entre os anos de 1848 e 1852. A área de interesse desses naturalistas abrangeu o Norte do Brasil, principalmente a Amazônia (FERREIRA, 2006).

As descrições feitas por Bates, documentadas em seu livro "Um naturalista no Rio Amazonas" (1863), abordavam tanto a fauna como a flora das florestas, incluindo diversos aspectos como a classificação das espécies brasileiras e a comparação com espécies européias, as características topográficas, além de comparar os animais e plantas de diferentes áreas dentro do território brasileiro. Ao mesmo tempo em que descrevia os aspectos da vegetação, incluía em suas descrições a sensação provocada pela paisagem. Muitas vezes, as descrições eram carregadas de encatamento, refletido na linguagem poética e fluida expressada pelo autor. A linguagem do texto, carregada de afetividade, é somada à descrição minuciosa de um espécime ou de uma paisagem. Uma forma não invalida a outra, as linguagens completam-se, permitindo que o leitor envolva-se na descrição dos objetos de estudo, despertando sua imaginação.

A leitura livre das descrições do naturalista é extremamente prazerosa. Ao mesmo tempo, pode gerar um certo estranhamento. Esta percepção se dá devido aos diversos nuances estético-afetivos claramente presentes na narrativa do naturalista, que são praticamente inexistentes quando referimo-nos aos textos científicos atuais.

A Estética refletida pela sensibilidade pode ser notada nas descrições de Bates, em suas afirmações, como: "A Arte não teria conseguido reunir formas vegetais tão belas e harmoniosas como a Natureza havia feito ali." (BATES, 1979, p. 83). De uma 
maneira mais específica, ele relaciona seus objetos de estudo com a música: "No meio de toda essa solidão, o estrondo das cataratas nos parecia uma música bastante apropriada.” (BATES, 1979, p.63). A exteriorização de suas impressões ficou marcada em diversos trechos do seu trabalho, como:

Um dia vi um minúsculo espécime pertencente ao gênero Phaethornis tomando banho num regato [...]. Ao observá-lo refleti que os poetas não precisavam inventar elfos e gnomos uma vez que a Natureza colocava ao alcance da nossa mão tão minúsculos e maravilhosos seres (BATES, 1979, p.72).

O naturalista documentou a floresta brasileira de forma significativa, captando fenômenos não descritos anteriormente, como por exemplo, o mimetismo, além de ter contribuído com descrições da hidrografia da região.

Uma linguagem que abre espaço para a sensibilidade pode ser encontrada na ciência em trabalhos mais antigos, como nos textos produzidos pelos naturalistas viajantes. Atualmente, muitas vezes, a sensibilidade possui pouca representatividade nos estudos sobre os seres vivos em geral, tanto na linguagem escrita como no próprio processo de investigação científica. Os elementos naturais tornaram-se meramente instrumentos mensuráveis, estudados por métodos de quantificação e análise, desconsiderando-se uma exploração, entendimento e envolvimento com seus aspectos instrínsecos. A natureza pode tornar-se ao pesquisador algo instrumentalizado e distante, incentivando a visão do ser humano como exterior e dominador do natural, à parte da natureza e não parte constituinte dela.

Em relação à instrumentalização da natureza, para o filósofo fenomenólogo francês Maurice Merleau-Ponty (1908-1961):

A Ciência manipula as coisas e renuncia a habitá-las. Fabrica para si modelos internos delas e, operando sobre esses índices ou variáveis às transformações permitidas por sua definição, só de longe se defronta com o mundo atual. Ela é, sempre foi, esse pensamento admiravelmente ativo, engenhoso, desenvolto, este parti pris de tratar todo ser como "objeto em geral", isto é, a um tempo como se ele nada fosse para nós, e no entanto, se achasse predestinado aos nossos artifícios (MERLEAU-PONTY, 1960, p. 275).

Parece haver, deste modo, certo distanciamento entre o pensamento 
científico e o mundo sensível. Ao explorarmos as emoções que os objetos naturais nos provocam, resgatamos nosso desejo inato de admirar, voltando a "habitar" os elementos naturais ao nos relacionarmos com a sua essência, e assim, o anseio de conhecê-los deixa de ser mecânico e torna-se mais genuíno.

No meio científico, em diversos momentos, parece ter sido instituída uma separação entre a racionalidade e o que remete às emoções. Os elementos que possuem relação com a subjetividade são vistos com aversão, como se fosse possível instituir ao ser humano uma separação entre o pensar e o sentir. Assim, instaura-se uma dicotomia clara entre a cultura das humanidades, a que assume a subjetividade como parte das relações humanas com o mundo e o outro, e a cultura científica, que abarca o método científico e sua objetividade.

A objetividade científica é extremamente importante no processo de investigação, pois representa a cautela e o proceder metódico dos cientistas, a busca por uma atitude imparcial mediante os objetos de estudo. O "método científico" visa garantir que exista um rigor na ciência, buscando explorar as relações constantes e universais entre os fenômenos. O problema instaura-se quando a objetividade é supervalorizada e tomada como única opção em todos os contextos científicos, como algo totalmente independente de qualquer outro elemento exploratório do objeto de estudo.

A lacuna entre a cultura das humanidades e a cultura científica é verificada principalmente no século XX. A cultura humanística enquanto uma cultura genérica que, pela via da filosofia, do ensaio, do romance, alimenta a inteligência geral, enfrenta as grandes interrogações humanas, estimula a reflexão sobre o saber e favorece a integração pessoal dos conhecimentos. A cultura científica, bem distinta por natureza, separa as áreas do conhecimento, resultando admiráveis descobertas e teorias geniais, mas nem sempre uma reflexão sobre o destino humano e sobre o futuro da própria ciência. A cultura das humanidades tende a se tornar um moinho despossuído do grão das conquistas científicas sobre o mundo e sobre a vida, que deveria alimentar suas grandes interrogações. A cultura científica privada da reflexão sobre os problemas gerais e globais torna-se incapaz de pensar sobre si mesma e de pensar os problemas sociais e humanos que coloca (MORIN, 2001).

O mundo técnico e científico identifica na cultura das humanidades uma 
espécie de ornamento ou luxo estético. O mundo das humanidades identifica na ciência um amontoado de saberes abstratos (MORIN, 2001). Ambas culturas possuem suas singularidades que as dintinguem e as distanciam. Porém, por ambas serem frutos da mente humana e de seus anseios, ambas culturas deveriam dialogar e se inter-relacionar, completando-se no entendimento humano. Quando essa discussão é colocada no âmbito do ensino, fica evidente a importância do diálogo entre o mundo das humanidades e das ciências, gerando metodologias e abordagens mais integradoras em sala de aula.

Todo ser humano é constituído por uma rede complexa que se dá por meio de um entrelaçamento de diversas dimensões, sendo elas afetivas, cognitivas, biológicas, sociais, dialógicas, etc. Portanto, é por meio de um conjunto de dimensões e aspectos entrelaçados complexamente que se constitui a totalidade de uma pessoa (TONIOLO, 2010).

Damásio (2001), com base em seus estudos sobre Neurobiologia, afirma que as emoções são inseparáveis e imprescindíveis nos processos de raciocínio e nas modulações das características cognitivas que permitiram a evolução da espécie humana.

O ser humano é feito para crescer, sendo ontologicamente chamado a desenvolver, nos limites e nas limitações de seu contexto histórico, suas potencialidades materiais e imateriais, buscando dosar adequadamente seu protagonismo no enorme leque de relações que a vida lhe oferece, incluindo as relações no mundo e com o mundo, as relações intrapessoais, interpessoais, estéticas, de gênero, de etnia e de produção (CALADO, 2001).

O ser humano e suas ações são caracterizadas por uma soma de dimensões, mostrando-se ingênuo afirmar que pode ser somente razão quando the for conveniente. Maturana (2004) afirma que a emoção tem papel crucial na definição da ação. A emoção gera certo fazer que o transforma numa ou noutra ação, ou que o qualifica um comportamento dessa ou daquela classe.

Evidentemente, essa busca pela inexistência daquilo que remete à subjetividade, à afetividade, ou ao sentimento na ciência reflete-se no ensino das Ciências Naturais. A impessoalidade permeia tanto a relação que o aluno estabelece com o seu objeto de estudo quanto na relação do professor com o aprendiz.

A tendência de currículos tradicionalistas ou racionalistas-acadêmicos, que 
reforçam uma relação distante com o objeto de estudo, ainda prevalecem não só no Brasil, mas também nos sistemas educacionais de outros países. O objetivo dos cursos é basicamente transmitir informação (KRASILCHIK, 2000). Nesse sistema que supervaloriza a mera trasmissão de informação, a fragmentação do conhecimento é um elemento presente que dificulta o aprendizado e a compreensão dos fenômenos naturais. Morin (2001) trata a respeito da fragmentação dos conteúdos e o privilégio dos aspectos racionais nos processos de aprendizagem em detrimento de uma visão complexa dos fenômenos naturais.

Há uma inadequação cada vez mais ampla, profunda e grave quando os saberes são tratados separadamente e de forma impessoal, transmitidos de uma maneira fragmentada, compartimentados em disciplinas. Ao tratar temas complexos de forma fragmentada, tornam-se invisíveis os conjuntos, as interações e retroações entre partes e todo, as entidades multidimensionais e os problemas essenciais (MORIN, 2001).

A inteligência que separa e fragmenta o complexo do mundo em pedaços, fraciona os problemas, unidimensionaliza o multidimensional, bem como, atrofia as possibilidades de compreensão e de reflexão. Quanto mais o conhecimento se torna multidimensional, maior a incapacidade de pensar sua multidimensionalidade; quanto mais a crise progride, mais cresce a incapacidade de pensar a crise. Uma inteligência incapaz de perceber o contexto torna-se cega, inconsciente e irresponsável (MORIN, 2001).

A extrema racionalização dos conteúdos, a impessoalidade e a fragmentação do conhecimento são questões que permeiam de forma conjunta e que interferem negativamente a relação do aprendiz com o conhecimento. Uma forma de se combater essa postura adotada por muitos profissionais no sistema atual é resgatar a humanização do ensino.

A humanização das relações, ou seja, levar em conta o ser humano em sua totalidade, oportuniza reinventar o mundo, buscar o encantamento nas relações consigo e com os demais. Para Freire (2005), este é o objetivo central da educação libertadora, cujo desafio maior reside na esperança de reinventarmos o mundo (NASCIMENTO; AZEVEDO; GHIGGI, 2013).

A aprendizagem significativa está refletida em uma relação de diálogo e afetividade entre o professor e o aprendiz, sendo que ambos comunicam e constroem o 
conhecimento conjuntamente.

Toda a aprendizagem, inclusive dos conteúdos científicos, possui uma dimensão afetiva. Sentimentos e emoções modulam as atitudes, os gostos, a disposição e a motivação em aprender, pois estes promovem encantamento e curiosidade (WATTS, 2001). A relação pedagógica quando perpassada pela afetividade e pela dialogicidade, oportuniza o desenvolvimento da educação como prática de liberdade e de humanização. Não é possível exercer a docência, de forma autêntica e comprometida, sem vivenciar a afeição pelos educandos e pelo mundo, sem dialogar com os outros indivíduos que fazem parte do processo. O diálogo e o sentimento permeiam a relação professor e aluno; aluno e aluno; professor, aluno e o mundo (NASCIMENTO; AZEVEDO; GHIGGI, 2013).

Superar a forma fragmentada e ingênua de encarar o ato de educar é uma construção que exige mudança de visão e de atitude. Combater o entendimento de que o aprendizado é mera aquisição de informações é uma forma de buscar uma leitura mais crítica do mundo e de si mesmo.

Valorizar a educação que integra a afetividade e o diálogo no processo de ensino não significa que deve-se banalizar a objetividade da investigação e sua rigorosidade. Toniolo (2010) afirma que o processo educativo deve ser conduzido com rigorosidade, com competência técnico científica, sem que com isso sejam banidos do processo pedagógico os laços afetivos, interpessoais, dialógicos. Esses laços precisam ser resgatados, buscando transcender a mera transmissão mecânica dos conhecimentos e gerar uma aprendizagem de fato significativa, pautada na relação afetiva, horizontal, dialógica entre educando-educador.

Portanto, educar não é a simples transmissão de informações. Educar é propiciar situações de ensino e aprendizagem nas quais os educandos tenham acesso ao conhecimento sistematizado, desenvolvam suas potencialidades e ampliem sua compreensão acerca da realidade na qual estão inseridos, tornando-os seguros a assumir seu espaço no mundo. Nessa forma de buscar a educação reside a esperança na transformação da realidade (TONIOLO, 2010). 


\subsection{Em busca de uma Filosofia Estética}

Mediante o panorama apresentado, no qual foi explicitado a importância em levar-se em consideração a dimensão da afetividade, dos sentimentos, das emoções como parte constituite do ser humano em sua interação com o mundo e seus objetos, iniciamos uma busca dentro da Filosofia por teorias que tratassem como o ser humano interage com o mundo e como a afetividade interfere nessa relação. Neste processo, deparamo-nos com as teorias filosóficas que tratam a Estética.

O termo "estética" é largamente utilizado no senso comum e, usualmente, remete às questões relacionadas à aparência das coisas ou das pessoas. Porém, a despeito de suas conotações adotadas no senso comum, a Estética emerge dentro de um contexto filosófico, sendo conhecida como uma ciência que se relaciona à beleza ou aos sentimentos despertados por meio da admiração de algo considerado belo. A Estética também é conhecida como precedente à Filosofia da Arte que investiga aspectos relacionados às manifestações artísticas.

A palavra "estética" é derivada do grego aesthesis, significando sentir. A raiz grega aisth, no verbo aisthanomai, quer dizer sentir não com o coração ou com os sentimentos, mas com os sentidos, rede de percepções físicas (BARILLI, 1989). O termo é hoje tão largamente utilizado que pode servir para qualificar tanto as Filosofias do Belo, quanto a elegância de uma formula matemática, os objetos artísticos, ou até mesmo um crepúsculo, as cercanias do mar, um rosto trabalhado pelo tempo (SANTAELLA, 2000). Diz respeito à maneira como as coisas se apresentam aos nossos sentidos e à maneira como elas nos impressionam pela sua mera aparição diante de nós. Estética tem a ver com a aparência imediata das coisas.

A Estética tem sido discutida por diversos filósofos ao longo da história. Os problemas estéticos são tão antigos quanto a própria Filosofia, tendo recebido, nos muitos séculos que transcorreram desde Platão (428-348) até os dias atuais, as mais diversas entonações e interpretações (SANTAELLA, 2000).

Dentro do ramo da Filosofia, a Estética é parte constituinte das diversas teorias semióticas que surgiram a partir do século XIX, diferenciando-se das teorias linguísticas que investigam a linguagem verbal. As teorias semióticas tem como objetivo investigar os processos de signos dos mais variados tipos, desde a literatura, a 
pintura, a fotografia, o cinema, até a arquitetura e a música, entre outros. Visa o estudo de todo tipo de linguagem, seja verbal ou não-verbal. A Estética está presente tanto em teorias não-semióticas como em teorias semióticas, estudando os signos artísticos (SANTAELLA, 2000).

As teorias não-semióticas focam-se mais na questão do objeto estético, enquanto as teorias semióticas focam mais no signo estético, ou seja, na representação por parte de um intérprete de determinado objeto (SANTAELLA, 2000).

Dentro da linha da Estética Semiótica existem diversas escolas, sendo uma delas a Estética Semiótica Peirceana elaborada pelo filósofo Charles Sanders Peirce (1839-1914) (SANTAELLA, 2000) (Figura 1).

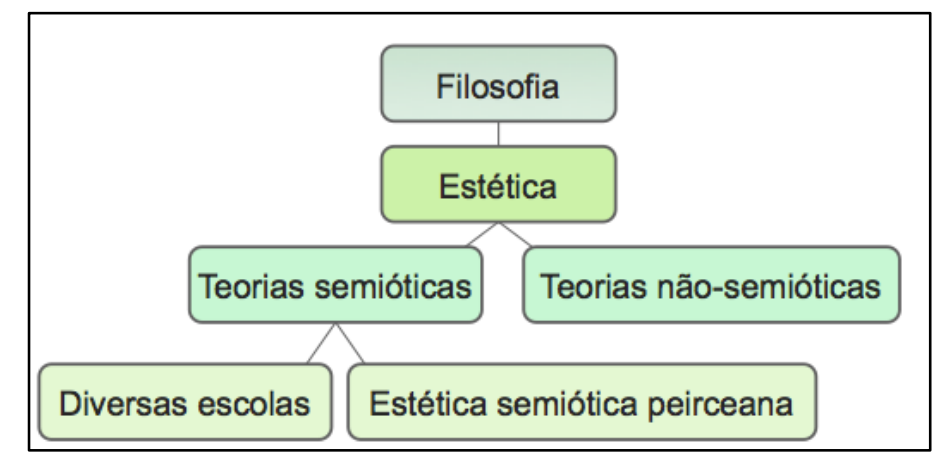

Figura 1. Esquema da configuração da Estética como parte da Filosofia. Fonte: adaptado de Santaella (2000, p. 12).

Peirce foi um cientista que contribuiu com trabalhos nas mais diversas áreas como Matemática, Física, Astronomia, Química, História, Psicologia, e principalmente a Lógica ou, para ele, Semiótica. Peirce (Figura 2) foi um conhecedor das obras de Immanuel Kant (1724-1804) que, assim como ele, possuía uma concepção arquitetônica da Filosofia e discutiu a Estética como uma de suas partes. 


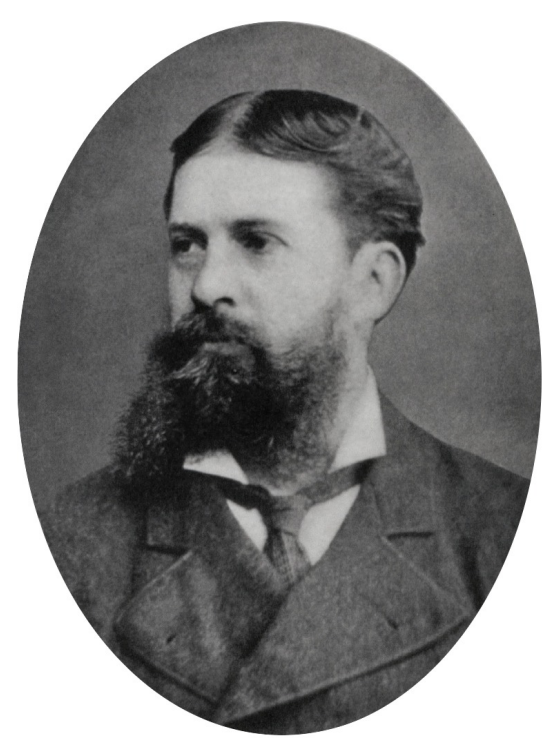

Figura 2. Retrato de Charles Sanders Peirce (1839-1914).

Fonte: http://philweb.rlwclarke.net/History/Twentieth/Pragmatism/Peirce/Peirce.htm

Peirce construiu um trabalho labiríntico, no qual o pesquisador tem que se deixar levar pelos meandros do material para decifrar onde começa e termina cada parte (WANNER, 2010). Embora Peirce tenha sido um matemático, lógico e filósofo, antes de tudo ele foi um homem das ciências. A Semiótica ou doutrina dos signos aconteceu como uma consequência de sua investigação sobre os mecanismos de pensamento e raciocínio de base, dando suporte aos métodos através dos quais as ciências conduzem suas investigações para atingir os resultados por elas almejados. A sua Filosofia buscou integrar, num todo coeso, a filosofia, a lógica e a ciência (SANTAELLA, 1994).

A Semiótica, como o estudo dos signos, surgiu para Peirce como uma consequência natural das descobertas que realizou dentro da própria Lógica, que se dedicou a estudar desde muito novo. Com apenas 12 anos deparou-se com a Lógica de Richard Whately (1787-1863), em sua adolescência com as cartas de Johann Christoph Friedrich von Schiller (1759-1805) e, posteriormente, com a Filosofia de Immanuel Kant (1724-1804), dando maior atenção à obra Crítica da razão Pura (Critique of Pure Reason, 1781). Peirce compreendia o mundo sob o prisma da semiótica. Para ele, toda forma de pensar e raciocinar se dava por meio de símbolos, sendo que, dentro de sua obra a Semiótica é um outro nome da própria Lógica. Concebeu a Filosofia como uma arquitetura, caracterizada não apenas como uma arquitetura filosófica, mas científica, ou seja, como uma filosofia científica (SANTAELLA, 1994). 
Com a progressão dos seus estudos, Peirce notou que a existência da Lógica por si só não era suficiente e que possuía uma incompletude, carecendo de outros elementos essenciais para melhor fundamentar sua teoria. Foi assim que desenvolveu seus estudos sobre a Ética e a Estética, para realizar as tarefas teóricas que a Lógica ou a Semiótica não podiam realizar por si mesmas. As ideias de Peirce a respeito da ciência não estavam presas na crença de métodos fixos. Toda leitura de sua obra deve levar em conta a integração que ele buscou para se ter a noção dos objetivos e ideais que o guiaram (SANTAELLA, 1994).

A Teoria Peirceana foi estabelecida como referencial teórico desta pesquisa, nomeadamente a parte de sua teoria que trata da configuração da Estética dentro de sua arquitetura filosófica e como ela atua em nossa relação e interpretação do mundo.

\subsection{Perguntas de pesquisa e objetivos}

O quadro teórico apresentado motivou as seguintes perguntas de pesquisa: Qual é a visão de Peirce sobre a Estética? Como a Estética relaciona-se com o ensino? Como utilizar a Estética Peirceana como ferramenta ao planejamento de atividades para estudo do meio? Utilizar os elementos estéticos em aulas de campo seria uma estratégia didática pertinente à abordagem da Biodiversidade?

Buscando respostas para as perguntas de pesquisa foram definidos os seguintes objetivos:

- Investigar o papel da Estética dentro da arquitetura filosófica elaborada por Peirce;

- Descrever a Estética como um elemento pertinente ao Ensino de Biologia;

- Elaborar um material didático para aulas de campo em cursos de Ciências Biológicas sob uma abordagem Estética. 


\section{CAPÍtULLO 2. \\ METODOLOGIA}

“Existir é estar numa relação. É tomar um lugar na infinita miríade das determinações do Universo."

Charles Sanders Peirce 


\subsection{Estudo teórico e levantamento bibliográfico}

$\mathrm{Na}$ primeira etapa da pesquisa estabeleceu-se que um estudo teórico seria realizado aprofundando-se no referencial da Filosofia de Peirce. Nas atividades desenvolvidas no Laboratório de Epistemologia e Didática da Biologia do Departamento de Biologia da Faculdade de Filosofia, Ciências e Letras de Ribeirão Preto da Universidade de São Paulo (FFCLRP-USP) outros trabalhos já haviam sido desenvolvidos utilizando a Teoria Semiótica de Peirce como ferramenta e base de discussão. Entretando, um aprofundamento na Teoria de Peirce, focado na Estética, ainda não havia sido realizado. Buscamos algumas fontes disponíveis em que Peirce tratou a Estética. Os trabalhos que adotamos como fonte primordial de análise foram $o s$ Escritos Coligidos, série de obras agrupadas de Peirce conhecidas como Collected Papers $^{1}$ (Figura 3).

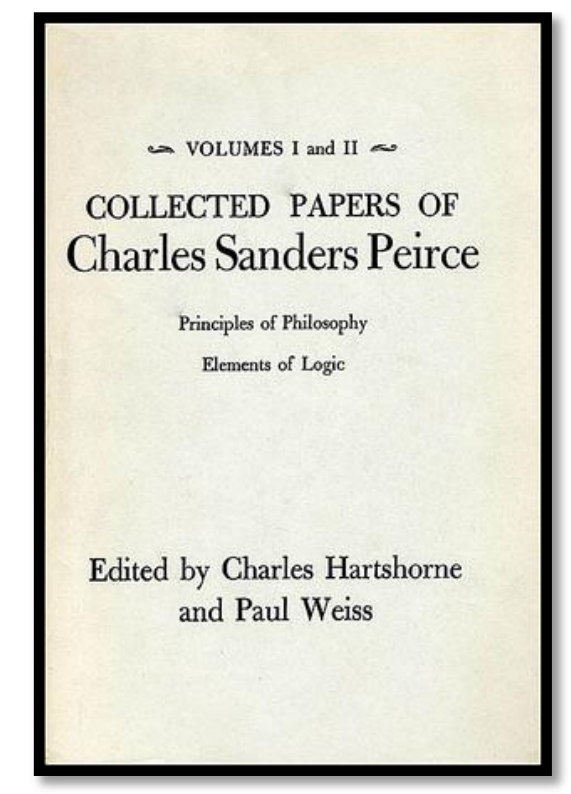

Figura 3. Collected Papers de Peirce, volumes I e II. A série de obras compreende cinco volumes no total.

Fonte: https:/book.douban.com/subject/4908720/

\footnotetext{
${ }^{1}$ Conforme convenção para obra de Peirce CP identifica os Collected Papers; seguindo-se números que indicam o volume e posteriormente os parágrafos.

${ }^{2}$ Parque Nacional (PARNA), considerado uma unidade de proteção integral reconhecida pelo Sistema Nacional de Unidades de Conservação (SNUC) como área em que se admite apenas o
} 
Também foram objeto de análise algumas outras fontes importantes que tratam a Filosofia de Peirce, como: os trabalhos de Santaella (1993; 1994; 2002) (Figura 4), Curley (1969) e Potter (1966), dentre diversos outros artigos e livros. Por se tratar de uma teoria complexa e extensa dentro da Filosofia de Peirce, o processo de investigação da Estética Peirceana se estendeu durante todo o período de desenvolvimento da pesquisa. Conforme o amadurecimento teórico da pesquisadora e mediante seu objeto de estudo, as interpretações e significados foram aprofundados.

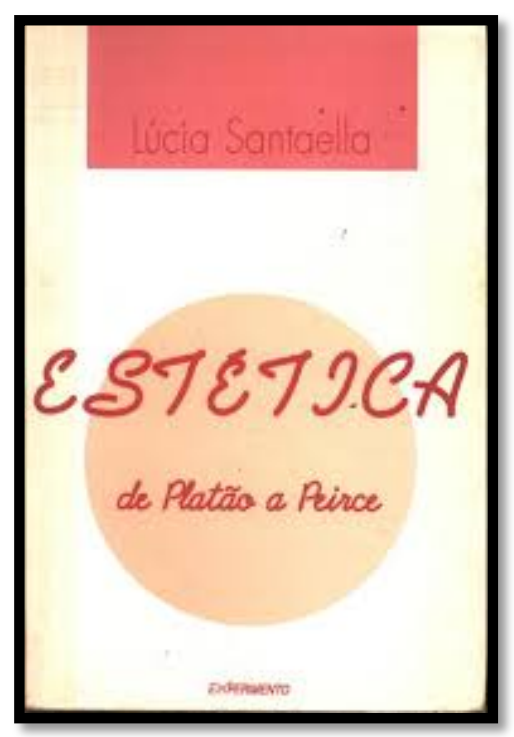

Figura 4. Livro Estética: de Platão a Peirce de Santaella (1994), uma das principais obras da autora utilizada na pesquisa.

Fonte: https://www.traca.com.br/livro/886454/estetica-platao-peirce/

Após imersão nos referenciais que tratam da Teoria Peirceana, passamos para a fase de levantamento bibliográfico por trabalhos de estudiosos que estabelecessem um diálogo com as ideias de Peirce, mas que apresentassem elementos que fossem voltados ao campo da Biologia, especificamente à área de Ensino de Ciências e Biologia. Encontramos no trabalho do cientista Aldo Leopold (1887-1948) intitulado A Sand County Almanac and Sketches Here and There (1949), (traduzido em português com o título Pensar como uma montanha, 2014), que trata de uma Estética direcionada à conservação da natureza, que apresenta categorias concernentes aos momentos de interação do ser humano com o ambiente natural. Essas categorias foram norteadoras na elaboração da sequência didática (como será apresentado nos próximos capítulos). 
O estudo das obras citadas fundamentaram a etapa seguinte da pesquisa, caracterizada pelo planejamento inicial de uma Sequência Didática para o Ensino de Biologia com foco em aulas de campo, tendo a Estética como embasamento.

\subsection{Planejamento da sequência didática}

A sequência didática elaborada possui como público alvo alunos do Ensino Superior de cursos de graduação em Ciências Biológicas. O local escolhido para o desenvolvimento das atividades foi o Parque Nacional da Serra da Canastra ${ }^{2}$, por ser um dos mais importantes parques nacionais brasileiros com um cenário de grande beleza, sendo representante da Mata Atlântica e do Cerrado, contando, ainda, com a presença do Rio São Francisco e de diversos outros afluentes importantes.

O Parque Nacional da Serra da Canastra é uma Unidade de Conservação (UC) cuja gestão é responsabilidade do Instituto Chico Mendes de Conservação da Biodiversidade (ICMBio). O ICMBio é uma autarquia em regime especial, criado em 2007 pela Lei 11.516, vinculado ao Ministério do Meio Ambiente (MMA). Cabe ao Instituto executar as ações do Sistema Nacional de Unidades de Conservação (SNUC), podendo propor, implantar, gerir, proteger, fiscalizar e monitorar as UCs instituídas pela União (ICMBIO, 2016).

O Parque está incluído nos domínios do bioma Cerrado, apresentando praticamente todas as fitofisionomias que englobam formações florestais, savânicas e campestres. Apesar de situar-se na região do bioma Cerrado, a proximidade com o domínio da floresta Atlântica faz com que as florestas nesta região apresentem diversos elementos comuns a este ambiente. Assim, elementos comuns à floresta Atlântica concentram-se em zonas mais úmidas e de solos mais férteis, enquanto aqueles de Cerrado predominam sobre os solos mais drenados e de menor disponibilidade de nutrientes (ICMBIO, 2005).

Com o intuito de elaborar aulas de campo que possuíssem elementos novos, buscando integrar a afetividade e o encantamento dos alunos, elementos que se distanciam das aulas de campo usualmente realizadas nos cursos de graduação em Ciências Biólogicas, buscamos investigar quais estudiosos haviam estudado o ambiente

\footnotetext{
${ }^{2}$ Parque Nacional (PARNA), considerado uma unidade de proteção integral reconhecida pelo Sistema Nacional de Unidades de Conservação (SNUC) como área em que se admite apenas o uso indireto dos recursos naturais, como o turismo ecológico e pesquisas científicas. (BRASIL, 2015)
} 
da Serra da Canastra. Nesta busca, deparamo-nos com o trabalho do naturalista viajante Auguste de Saint-Hilaire (1779-1853). O botânico francês viajou pelo Brasil entre os anos de 1816 e 1822 e escreveu livros nos quais descreveu os costumes brasileiros e a paisagem que encontrou.

O naturalista percorreu uma trilha que abrangia toda a extensão do Rio São Francisco e em seu livro Viagem às nascentes do Rio São Francisco e pela província de Goiás (1937) (Figura 5) descreveu com riqueza os elementos encontrados. Na Serra da Canastra, suas descrições da paisagem são repletas de detalhes e emoções.

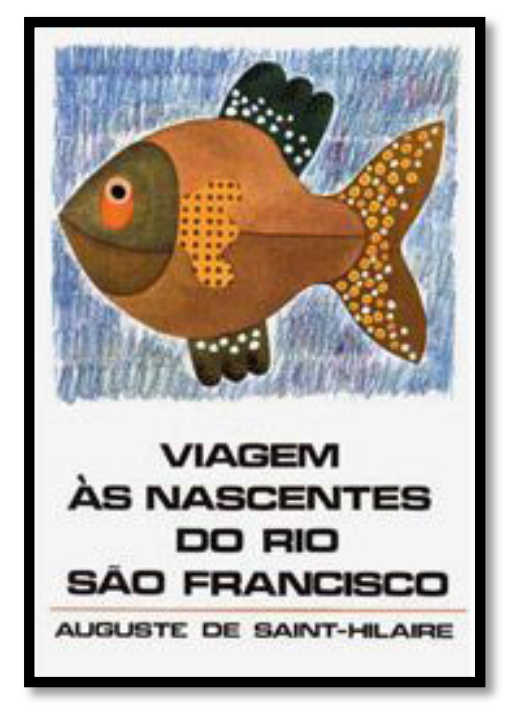

Figura 5. Livro de Auguste de Saint-Hilaire (1779-1853) utilizado como base para o planejamento das aulas.

Fonte: http://www.submarino.com.br/produto/5782757/livro-viagem-as-nascentes-do-rio-saofrancisco

Ao depararmo-nos com os ricos relatos de Saint-Hilaire decidimos que utilizaríamos seus escritos como pano de fundo das aulas de campo, como proposta de investigação do ambiente da Serra da Canastra, revisitando os pontos traçados pelo naturalista em sua expedição tendo os relatos como base de consulta. Os alunos teriam que analisar a paisagem em geral, assim como a hidrografia da região e a relação que os seres vivos desse ambiente possuem com o Rio São Francisco.

Mediante um planejamento inicial, definimos: embasamento teórico, a Estética Peirceana e as categorias de Aldo Leopold; público alvo, os alunos de graduação do curso de Ciências Biológicas; local, o Parque Nacional da Serra da Canastra; pano de fundo e guia para a elaboração das aulas de campo, a trilha realizada 
por Saint-Hilaire nas margens do Rio São Francisco. Desta forma, a Filosofia representada pela Estética e os relatos de Saint-Hilare configuraram-se ferramentas à elaboração da Sequência Didática.

\subsection{Expedição à Serra da Canastra}

Após termos realizado o planejamento incial das nossas aulas de campo, analisamos detalhadamente a narrativa de Saint-Hilaire a respeito de sua trilha na Serra da Canastra, buscando identificar o percurso realizado por ele e os objetos naturais do local que despertaram a sua atenção e admiração. Preparamos e realizamos uma expedição à Serra da Canastra entre os dias 24 e 26 de agosto de 2016, que contou com a participação de outras pesquisadoras do Laboratório de Espistemologia e Didática da Biologia. Nossa intenção era refazer a trilha exata realizada pelo naturalista e identificar os elementos descritos em sua narrativa, ou pelo menos encontrar pontos específicos que o naturalista esteve para estimar o caminho percorrido (esses dados estão descritos no Capítulo 5).

Mediante a expedição para a coleta de dados, mapeamos os locais visitados pelo naturalista e os pontos da trilha que possuem elementos pertinentes a serem explorados nas aulas de campo, bem como o conteúdo específico a ser abordado nas aulas, considerando a expedição de Saint-Hilaire como eixo articulardor da proposta.

Porteriormente à expedição com a equipe do Laboratório, outra visita à Serra da Canastra foi realizada, oportunizada pela disciplina Sistemática Vegetal II do curso de graduação em Ciência Biológicas do Departamento de Biologia da FFCLRPUSP, tendo o Prof. Dr. Milton Groppo Junior como docente responsável. O mesmo local explorado na expedição anterior foi revisitado, sendo possível um aprofundamento sobre as características da vegetação na região.

\subsection{Proposição da sequência didática}

A elaboração e a proposição da sequência didática foi realizada após as duas visitas à Serra da Canastra. Mediante às informações coletadas e à análise dos locais visitados, possíveis trajetos e assuntos a serem tratados nas aulas de campo foram levantados, e assim, passamos para a fase criativa. Visando explorar as categorias de Aldo Leopold (1949) e tendo a Estética de Peirce como referenciais teóricos, a 
Sequência Didática foi elaborada, sendo que cada item sugerido foi pensado de forma proposital, atendendo a determinados interesses.

Para elucidar o percurso metodológico adotado, no Quadro 1 estão descritas as fases da pesquisa e na Figura 6 é apresentada uma arquitetura geral da pesquisa, explicitando como os elementos contidos no corpo da pesquisa interelacionam-se.

Quadro 1. As etapas da pesquisa e suas descrições.

\begin{tabular}{|c|c|}
\hline \multicolumn{2}{|c|}{ Etapas da Pesquisa } \\
\hline $\begin{array}{l}\text { 1) Aprofundamento no referencial } \\
\text { teórico da Estética Peirceana }\end{array}$ & $\begin{array}{l}\text { Busca e estudo das obras de Peirce e de } \\
\text { outras fontes que abordam a Teoria de } \\
\text { Peirce. }\end{array}$ \\
\hline $\begin{array}{l}\text { 2) Levantamento bibliográfico de } \\
\text { trabalhos que dialogam com as ideias } \\
\text { de Peirce }\end{array}$ & $\begin{array}{l}\text { Foco nos trabalhos voltados ao Ensino de } \\
\text { Ciências e Biologia. Estudo das ideias de } \\
\text { Aldo Leopold (1949). }\end{array}$ \\
\hline $\begin{array}{l}\text { 3) Planejamento incial da sequência } \\
\text { didática }\end{array}$ & $\begin{array}{l}\text { Escolha do público alvo, local, pano de } \\
\text { fundo e ideias iniciais. }\end{array}$ \\
\hline 4) Expedição à Serra da Canastra & $\begin{array}{l}\text { Revisitação dos pontos traçados por Saint- } \\
\text { Hilaire em seus relatos e observação do } \\
\text { ambiente. }\end{array}$ \\
\hline 5) Proposição da sequência didática & $\begin{array}{l}\text { Aulas de campo estruturadas tendo a } \\
\text { Estética como embasamento. }\end{array}$ \\
\hline
\end{tabular}


ARQUITETURA DA PESQUISA

Questão motivadora: ciência apresentada de forma fragmentada e impessoal
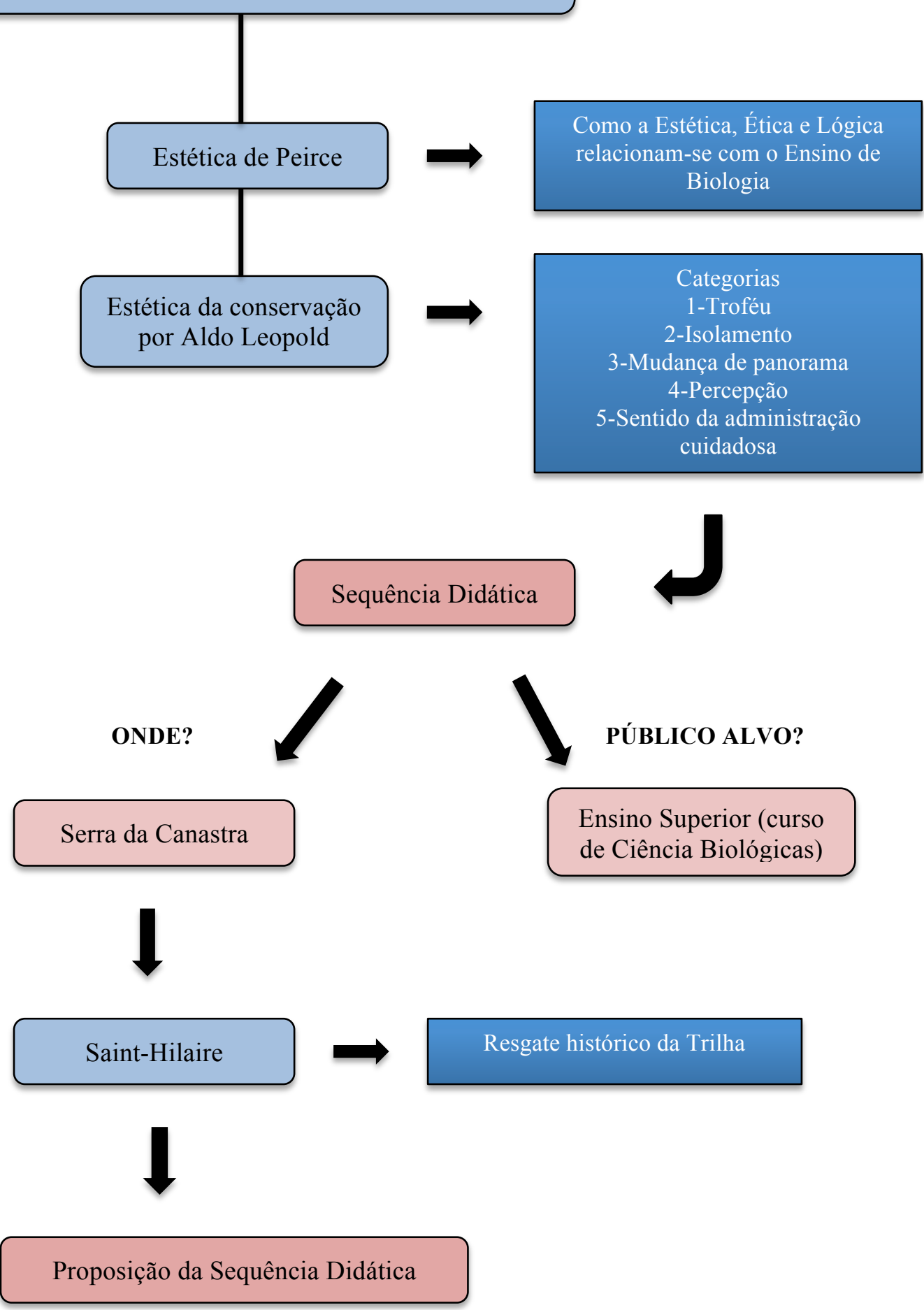

Figura 6. Esquema apresentando a arquitetura geral da pesquisa. 


\section{CAPÍTULO 3. \\ A ESTÉTICA, A ÉTICA E A LÓGICA EM NOSSA RELAÇÃO COM O MUNDO}

"[...] é o prazer estético que nos interessa."

Charles Sanders Peirce (CP 5.113) 


\subsection{O referencial teórico}

A Filosofia de Peirce possui ampla coesão em suas partes, sendo que cada elemento está interconectado com outros elementos e cada parte não deve ser vista e analisada isoladamente. Entretanto, antes de tratarmos sobre a organização da Filosofia de Peirce, mostra-se essencial compreender a relevância da estrutura triádica na Teoria do filósofo. A estrutura triádica permeia todas as suas ideias. A tríade, de um primeiro, um segundo e um terceiro é sempre representada por categorias universais, passíveis de zserem aplicadas amplamente, sendo descritas pelo filósofo como essenciais na relação de uma mente capaz de interpretar fenômenos.

Os estudos realizados por Peirce o levaram a postular tais categorias, sendo três elementos formais que residem em toda experiência e, por conseguinte, todo conhecimento, sendo elas:
1) A qualidade
2) A relação
3) A representação

Essas categorias, que podem ser aplicadas a qualquer fenômeno de qualquer espécie foram, posteriormente, formalmente denominadas de primeiridade, secundidade e terceiridade (SANTAELLA, 1994).

A primeiridade seria como um primeiro olhar sobre algo, um sentimento sem reflexão, o que está na consciência em um simples momento, uma primeira apreensão das coisas sem estabelecimento de relações, um primeiro contato de uma forma imprecisa e indeterminada com o fenômeno (SANTAELLA, 1983). A primeiridade é a qualidade rara de ver o que está diante dos olhos, como se apresenta, não substituído por alguma interpretação.

A concepção epistemológica peirceana das três categorias tem um destaque especial na primeiridade, na contemplação (WANNER, 2010). De acordo com Peirce:

Ao contemplar uma pintura, há um momento em que perdemos a consciência do fato de que ela não é uma coisa. A distinção do real e da cópia desaparece e por alguns momentos é puro sonho; não é qualquer existência particular e ainda não é existência geral. Nesse momento, estamos contemplando um ícone (CP 3.362). 
A Secundidade está relacionada à ideia de ação e reação, conflito com o real. A terceiridade diz respeito à generalidade, corresponde à camada da inteligibilidade, ou seja, pensamentos em signos, por meio do qual representamos e interpretamos o mundo (SANTAELLA, 1983).

O que é passível de investigação para Peirce são os fenômenos que necessitam ser observados e que se impõem a quem os observa. Esses fenômenos nada mais são que a experiência diária, comum a todos os seres humanos (SILVEIRA, 2002). Ou seja, a todo o momento o ser humano está investigando e conhecendo ao se deparar com os fenômenos de seu cotidiano.

Perceber algo não requer apenas oberservar, mas estar diante de algo que se apresenta, que deve ser apreendido através de todos os sentidos. Assim, a Filosofia Peirceana entende a realidade fenomenologicamente, ou seja, o real é tudo aquilo que se exterioriza e se coloca à experiência por meio das categorias: primeiridade, secundidade e terceiridade (WANNER, 2010).

Passamos por essas categorias ao nos depararmos com os objetos do mundo que nos cerca, sendo esse processo dinâmico e nada linear. Dessa forma, representamos e significamos o mundo por meio de nossos sentidos. Para Peirce, o conhecimento é derivado de nossa experiência mediata de mundo, por meio de signos, a partir de outros conhecimentos já adquiridos de forma mais simples, num processo contínuo, denominado semiose (CALDEIRA, 2007).

O signo, na perspectiva peirceana, é entendido como qualquer coisa de qualquer espécie que representa uma outra coisa, chamada objeto do signo, e que produz um efeito interpretativo em uma mente real ou potencial, efeito esse chamado de interpretante do signo (SANTAELLA, 1983). De acordo com Peirce (1972, p. 94): “Um signo, ou representamen, é algo que, sob certo aspecto ou de algum modo, representa alguma coisa para alguém".

Tanto quanto o próprio signo, o objeto do signo também pode ser qualquer coisa de qualquer espécie. Essa "coisa" qualquer está na posição de objeto porque é representada pelo signo. O que define, portanto, signo, objeto e interpretante é a posição lógica que cada um desses três elementos ocupa no processo interpretativo (SANTAELLA, 2009).

"O signo é um primeiro (algo que se apresenta à mente), ligando um segundo (aquilo que o signo indica, se refere ou representa) a um terceiro (o efeito que o signo irá provocar em um possível interprete)" (SANTAELLA, 2002, p. 07). 
A importância em estudar e entender o signo deve-se ao fato de que, para Peirce, pensamos somente através de signos e todas as relações de significação que geramos em nosso contato com os fatos são relações sígnicas.

\subsection{A arquitetura filosófica de Peirce}

Peirce aplicou-se intensamente à elaboração de uma classificação das ciências que o satisfizesse, dedicando anos de sua vida nesse processo, pois almejava que o todo de sua Teoria se relacionasse de maneira coerente. Dessa forma, o significado de cada ciência dentro de sua classificação só faz sentido na rede de interrelações que ela entretém com as demais (SANTAELLA, 1994).

Quando buscamos compreender o que é a Estética e a forma como ela está presente na Teoria de Peirce, primeiramente, deve-se possuir uma noção geral da arquitetura filosófica elaborada pelo filósofo e como as categorias universais (primeiriade, secundidade e terceiridade) integram-se nessa rede. Um diagrama da arquitetura encontra-se na Figura 7.

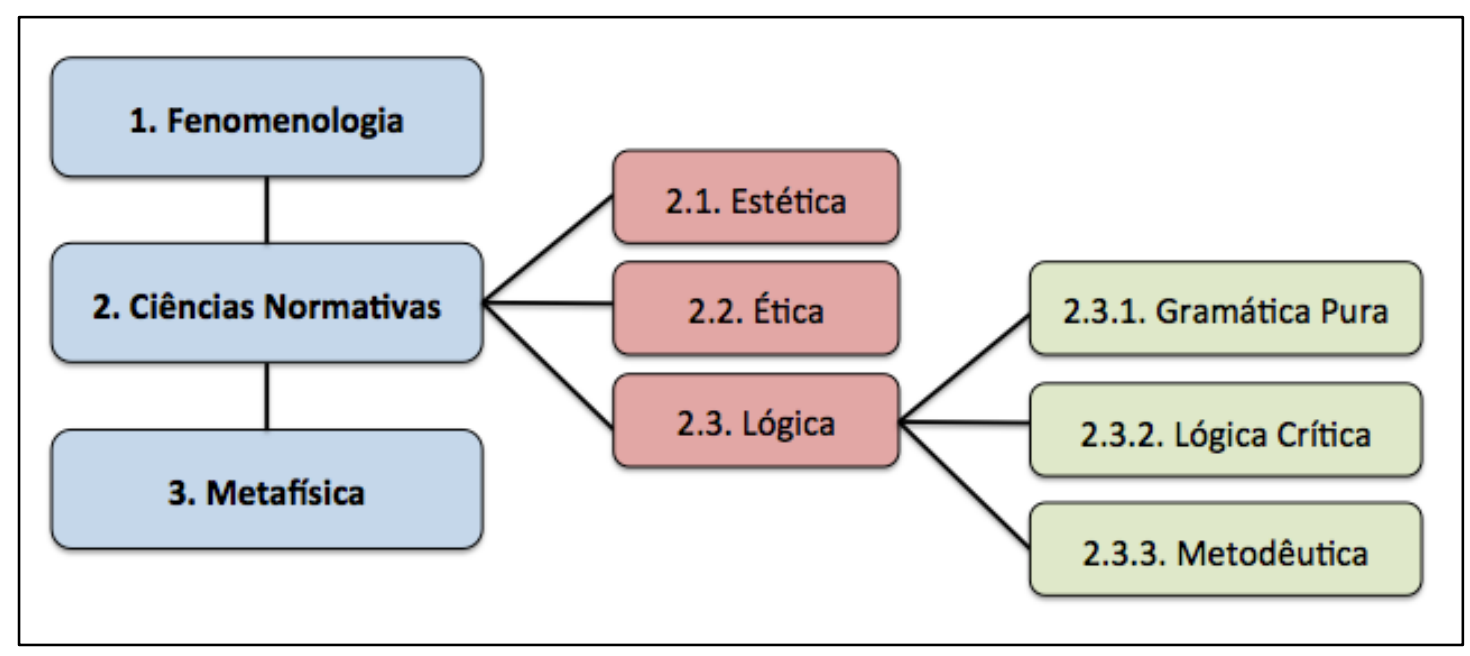

Figura 7: Diagrama representando a organização esquemática da arquitetura filosófica de Charles Sanders Peirce. Fonte: adaptado de Santaella (1994).

Para melhor elucidar o diagrama da ampla arquitetura filosófica de Peirce, é preciso compreender que para ele a Filosofia em geral tem por tarefa descobrir aquilo que representa a "verdade". A Filosofia não remete à noção de uma verdade absoluta, limita-se à verdade que pode ser inferida por meio da experiência comum do ser 
humano, tida em todo e qualquer momento. A mais árdua e primordial tarefa que a Filosofia tem de enfrentar é a de dar à luz as categorias mais universais da experiência (SANTAELLA, 1994).

As ideias de Peirce são categorizadas no sistema disposto sob a forma de um edifício filosófico, subdividido em: I-Fenomenologia; II- Ciências Normáticas; IIIMetafísica.

A Fenomenologia, apresentada na base no diagrama proposto pode ser considerada uma quase ciência que tem por função fornecer o fundamento observacional para o restante das disciplinas filosóficas (SANTAELLA, 1994). Para Peirce a Fenomenologia é a base fundamental para qualquer ciência, constituindo-se da observação dos fenômenos. Somente conhecemos o mundo ao nos depararmos com os fenômenos em nossa experiência. Por meio da análise desses fenômenos é que torna-se possível o estabelecimento das categorias universais que podem abarcar toda e qualquer experiência e pensamento. Em relação à Fenomenologia, Peirce afirma:

Fique entendido que o que temos a fazer enquanto estudantes de fenomenologia é simplesmente abrir os olhos do espírito e olhar bem os fenômenos e dizer quais suas características, quer o fenômeno seja externo, quer pertença a um sonho, ou uma ideia geral e abstrata de ciência. (PEIRCE, 1980, p. 16)

O sistema filosófico de Peirce está alicerçado pela Fenomenologia que tem por objetivo investigar os modos como aprendemos qualquer coisa que se apresente à nossa mente, como por exemplo, a imagem de uma paisagem, o cheiro de uma flor, a formação de nuvens no céu, a lembrança de algo vivido, até algo mais complexo como um conceito abstrato (SANTAELLA, 2002).

A segunda disciplina apresentada em sua Filosofia denomina-se Ciências Normativas e estão voltadas para a compreensão dos fins, das normas e ideais que regem o sentimento, a conduta, e o pensamento humano. Considerando que a Fenomenologia estuda os fenômenos tal como aparecem, as Ciências Normativas estudam os fenômenos na medida em que podemos agir sobre eles e eles sobre nós.

Para que o entendimento das Ciências Normativas seja completo, deve-se entender a Fenomenologia primeiramente. Ao observarmos os fenômenos encontrados na experiência comum para extrair deles as mais simples generalizações, a Fenomenologia se apresenta como alicerce de toda Filosofia, pois seus conceitos simples e elementares dão sustento a todo o edifício filosófico (SANTAELLA, 19940; 
SENICIATO; CAVASSAN; SILVA, 2006).

As Ciências Normativas estão voltadas para o modo geral pelo qual o ser humano deve responder às experiências, ou seja, quais os elementos que norteiam o modo de agir em relação aos fenômenos. A Fenomenologia trata de como os fenômenos agem sobre nós, já as Ciências Normativas voltam-se para a forma como nós reagimos em relação aos fenômenos, quais elementos estão envolvidos em nossa reação.

Em relação à terceira disciplina descrita por Peirce, temos a Metafísica. Ela investiga o que é real para nós, na medida em que esse real pode ser averiguado na experiência comum. É dela a tarefa de fazer a mediação entre a Fenomenologia e as Ciências Normativas, desenvolvendo uma teoria da realidade (SANTAELLA, 1994).

Nesta pesquisa o foco é a Estética, sendo que as outras disciplinas tratadas por Peirce poderão ser objeto de futuras investigações.

Ao depararmo-nos com os elementos da Filosofia de Peirce, devemos levar em consideração a estrutura triádica já abordada. Deve-se atentar para o papel crucial desempenhado pela Lógica ternária no conteúdo e ordenação da arquitetura filosófica de Peirce. Os números, no diagrama dessa arquitetura, não são somente ordenadores, mas indicam uma relação lógico-relacional em cada um dos itens do diagrama.

Onde encontramos o número 1, a categoria da primeiridade está sendo indicada - a da qualidade, sentimento, acaso, indeterminação. Onde houver o numero 2, o existente, ação, o universo dual da secundidade está operando. Onde houver o número 3, o governo da lei, a continuidade o crescimento, a inteligibilidade, que são próprios da terceiridade, estão implicados. Portanto, enquanto a Fenomenologia é um primeiro, abarcando as características da primeiridade essencialmente, a Estética é o primeiro do segundo, quer dizer, como Ciência Normativa ela está marcada pela secundidade primordialmente, mas, diferentemente da Ética, que é secundidade mais pura, a Estética está no nível da primeiridade dessa mesma secundidade (SANTAELLA, 1994). Dessa forma, as categorias da primeiridade, secundidade e terceiridade expressam-se em todas as ciências dispostas no seu edifício filosófico.

Finalmente, para Peirce, sua arquitetura filosófica não se sustenta de forma isolada mas, encontra-se inserida dentro de um grande diagrama das ciências com as quais a Filosofia possui diferentes relações. 


\subsection{As Ciências Normativas e o crescimento em importância da Estética na Teoria de Peirce}

Em relação às Ciências Normativas apresentadas no diagrama (Figura 7), considera-se normativo o estudo do que deve ser, ou pode influenciar, excluindo de seu campo tanto a compulsão incontrolada quanto o determinismo rígido. Com as Ciências Normativas, Peirce estava repensando os fins, propósitos, valores, metas e ideais que atraem e guiam a conduta deliberada por cada indivíduo. O que as Ciências Normativas apresentam é a busca em compreender como o Sentimento, a Conduta e o Pensamento devem ser controlados, supondo-se que eles estejam em certa medida passíveis ao autocontrole por cada indivíduo, oferecido por meio da autocrítica e da formação propositada de hábitos (SANTAELLA, 1993; 1994).

Peirce apresenta que a nossa interpretação do mundo não se limita somente à mente deparando-se com objeto, resultando na exata interpretação deste. A nossa resposta em relação aos fenômenos do mundo exterior é guiada e influenciada por outros elementos inerentes à mente potencial, sendo estes elementos representados pelas Ciências Normativas.

Tais Ciências desenvolvem-se seguindo a Estética, a Ética e a Lógica. A Estética pode ser definida como a ciência daquilo que é objetivamente admirável, dispondo-se como base para a Ética. Sob ambas as Ciências, Estética e Ética, configurase a Semiótica ou Lógica.

A Estética, portanto, tem por objetivo investigar os sentimentos que guiam nossos ideais, a Ética se empenha em definir quais ideais orientam nossa conduta e a Lógica estuda que ideias e normas guiam nossos pensamentos (SANTAELLA, 1994).

Em suma, a ética apóia-se numa doutrina que, sem considerar o que deva ser nossa conduta, divide os estados idealmente possíveis das coisas em duas classes, admiráveis e inadmiráveis, e empenha-se em definir precisamente o que é que constitui a admirabilidade de um ideal. [...] Chamo esta investigação de Estética, porque se diz geralmente que as três ciências normativas são lógica, ética e estética [...]. É evidentemente [a estética] a ciência normativa básica sobre que se deve apoiar a ética, que é por seu turno sobrepujada pela doutrina da lógica. (PEIRCE, 1983, p.14)

Na obra de Peirce, a Estética não adquiriu inicialmente um papel central. Porém, conforme o filósofo foi amadurecendo e aprofundando suas ideias, afirmava em 
seus escritos que a Estética começou a ganhar uma maior importância dentro de sua Teoria, tendo sido negligenciada por ele em momentos anteriores. $\mathrm{O}$ reconhecimento do papel crucial da Estética em sua arquitetura filosófica foi o fator que o levou a reconsiderar a sua proposição inicial do Pragmatismo.

O Pragmatismo é uma corrente filosófica norte-americana do final do século XIX, idealizada inicialmente por jovens pensadores de Cambridge (Massachusetts, USA), dentro os quais Peirce, que encontravam-se para debater questões filosóficas. De acordo com Willian James (1842-1910), a doutrina filosófica conhecida como Pragmatismo foi originalmente proposta por Peirce (COLLEGE, 1934). Porém, mediante as novas descobertas dentro de sua Teoria, Peirce passou a discordar da ideia de Pragmatismo inicialmente proposta e discutida juntamente com seus colegas.

Especialmente a partir de 1900, a Estética passou a ocupar um lugar proeminente na arquitetura filosófica de Peirce e, a partir desta nova compreensão, ele formulou o seu segundo pragmatismo, rebatizando-o sob o título de Pragmaticismo. Em 1901, Peirce passou a entender a importância dos fins ou ideais na Filosofia. Com isso, determinou que a Ética seria o alicerce da Lógica. Um ano mais tarde, expôs que a Ética estaria alicerçada na Estética e que caberia à ela a descoberta do ideal supremo da vida humana. Ele possuía muitas dúvidas e incertezas quanto à natureza desse ideal que caberia à Estética trazer à luz (SANTAELLA, 1994).

A estética e a ética parecem pertencer a universos diferentes. [...]. Foi só recentemente que fui persuadido de que essa aparência é ilusória e de que, ao contrário, a lógica precisa da ajuda estética. Mas, o assunto não está muito claro para mim (CP 2.197).

Peirce optou por essa reformulação para enfatizar que discordava do Pragmatismo discutido por outros autores, que havia sido inspirado em suas ideias. Em uma carta dirigida a William James, em 25 de novembro de 1902, Peirce afirmou:

Minha própria visão de 1877 era crua. Mesmo quando dei minhas palestras em Cambridge, não havia chegado ao cerne da questão, deixando de ver a unidade da coisa toda. Não foi senão depois disso que obtive a prova de que a lógica deve estar fundada na ética, da qual ela é um desenvolvimento mais elevado. Mas mesmo então, por algum tempo, fui tão imbecil a ponto de não ver que a ética, do mesmo modo, está fundada sobre a estética - pela qual, desnecessário mencionar, eu não quero significar leite, água e açúcar (CP 8.255).

Por volta de 1902, Peirce se deu conta de quão crua tinha sido sua primeira 
apresentação da Máxima Pragmática, em 1878, em um texto intitulado Como tornar claras as nossas ideias (How to make our ideas clear) (CP 5.388-410). Nessa época, Peirce identificou o significado dos conceitos intelectuais com os efeitos acessíveis aos sentidos, e isso relacionava-se com ação e reação. Porém, ele não havia considerado que a ação só poderia ser entendida em termos de propósito e que propósito seria essencialmente pensamento. Com isso, seu Pragmatismo inicial acabou disseminado de maneira limitada e errônea, sendo atualmente largamente definido como uma corrente de ideias que prega que a validade de uma doutrina é determinada pelo seu bom êxito prático (SANTAELLA, 1994). Peirce discordava dessa noção amplamente disseminada. Para ele os "raptores do seu filhote", nominalistas inveterados, nunca conseguiram entender que a verdadeira natureza do Pragmatismo não poderia ser entendida sem as categorias descritas em sua obra (CP 8.256).

Enquanto as versões populares do Pragmatismo tinham a ação como finalidade última da vida, para Peirce, a interação indissolúvel das três categorias e das Ciências Normativas dizia respeito ao fim último que todo ser humano buscaria como algo que dava sanção à ação. Envolvia a ação, mas não poderia ser identificado com ela.

Toda ação supõe fins, mas os fins estão no modo de ser do pensamentosigno que não está simplesmente na consciência, mas permeia todos os fenômenos. Qualquer outra coisa que qualquer coisa possa ser, ela também é um signo: esse era o mote peirceano. O universo inteiro estaria impregnado de signos. O seu novo entendimento do Pragmatismo o levou a considerar que seu aspecto mais relevante estaria no fato de que o Pragmatismo busca fins, ou seja, toda ação volta-se para um fim. Esse fim, ou aquilo que é o bem humano supremo, consistia num processo de evolução no qual os existentes crescentemente iam dando corpo aos ideais reconhecidos como razoáveis (SANTAELLA, 1994).

As ações e reações são geradas por meio do pensamento, ligado aos efeitos causados pelos nossos sentidos. A ação não pode ser o ente último e isolado, já que, toda ação pressupõe um fim. Esta noção seria a chave para o entendimento da relevância da Estética Peirceana mas, Peirce só chegaria com clareza a essa visão aos 71 anos, quatro anos antes de morrer (SANTAELLA, 1994). Após as suas novas reflexões, o estudioso pôde concluir que a essência das Ciências Normativas só seriam encontradas na Estética, por esta lidar com o ideal em si mesmo. O fim último, o ideal supremo que o ser humano busca estaria intimamente relacionado à Estética, sendo esta então, o motor da ação. 


\subsection{As dificuldades na definição da Estética e de seu ideal último}

O pesquisador Thomas Curley (1969) afirma que todo pensamento lógico implica a adoção de um padrão de ação. Essa afirmação está baseada em uma determinação Ética sobre qual deve ser a aspiração de toda atividade humana deliberada. Do mesmo modo que a Lógica possui seu alicerce da Ética, esta também está fundada na Estética.

Como apresentado anteriormente, Peirce afirmou que a Ética deve ser alicerçada sobre uma doutrina que divide idealmente os possíveis estados de coisas em duas classes: aqueles que são admiráveis e aqueles inadmiráveis, buscando definir o que constitui a admirabilidade de um ideal (CP 5.36).

O ideal que Peirce apresentou seria o fim último em direção ao qual o esforço humano se dirige. Trata-se de um ideal supremo que ansiamos, que não precisa de nenhuma justificativa e explicação. A questão da Estética é determinar o que pode preencher este requisito de ser admirável, desejável, em si mesmo, sem qualquer razão ulterior (CP 2.199).

Cada ser humano é movido por um ou vários ideais, caracterizados como metas que almejamos alcançar, os planos que fazemos em longo prazo, os sonhos que acalentamos e que conduzem nossos passos. Portanto, nossa vida é baseada em ideais que justificam nossa existência, e que estamos em constante busca. Para muitos, a Ética tem sido o território de alocação do ideal coletivo supremo. De acordo com Peirce, o ideal que move o empenho Ético está além da Ética. O bem supremo, universal, válido para a humanidade como força de atração última seria determinado pela Estética, que seria o admirável sem qualquer razão ulterior (SANTAELLA, 1994).

A Estética, enquanto uma ciência em nível de primeiridade, está ligada às ideias de indeterminação, acaso, qualidade, sentimento. Mas, é uma Ciência Normativa, que visa os fins e propósito. Além disso, possui uma relação inseparável com as outras duas Ciências Normativas.

Apesar de atualmente a Estética ser superficialmente associada somente à ideia de beleza, Peirce afirmava que meramente associar a Estética a uma teoria do belo seria uma interpretação distorcida. Ao compreendermos a Ciência da Estética mais profundamente, a noção do belo configura-se como um resultado dessa ciência, e não sinônimo dela. O belo pode ser considerado como algo que foi admirável para diversas 
mentes potenciais, atraente para estes seres, fazendo parte de um consenso geral. O ideal estético, para Peirce, estaria relacionado com o admirável. Em seu anseio por definir a Estética, afirmou:

\begin{abstract}
Não temos em nossa língua uma palavra com a generalidade requisitada. O grego kalós ("admirável"), o francês beau apenas se aproximam, sem atingi-la diretamente na testa. Fine seria uma substituta patética. Beautiful é mau, porque um modo de ser kalós depende essencialmente de a qualidade ser não-bela. Talvez, contudo, a frase "the beauty of the unbeautiful" (o belo do não belo) não fosse chocante. Mas "beauty" (beleza) é ainda muito superficial. Usando-se kalós, a questão da estética é - qual é a qualidade que, na sua presença imediata, é kalós? Dessa questão a ética deve depender, do mesmo modo que a lógica depende da ética. A estética, portanto, embora eu a tenha negligenciado terrivelmente, aparece possivelmente como a primeira propedêutica para a lógica, e a lógica da estética aparece como uma parte distinta da ciência lógica que não deve ser omitida $(\mathrm{CP}$ 2.199).
\end{abstract}

Peirce buscava um nível de generalidade máxima, algo que fosse admirável em si e por si mesmo, sem qualquer razão, sem nenhum imperativo da denominação limitada da beleza.

Para Peirce, do mesmo modo que a Ética não estaria diretamente preocupada com o que é certo ou errado, mas com aquilo que deveria ser o alvo do esforço humano, a Estética não estaria voltada para o que é belo ou não-belo, mas para aquilo que deveria ser experimentado por si mesmo (SANTAELLA, 1994).

Peirce foi buscar no kalós grego, algo que toda alma vagamente deseja e muito mais vagamente percebe - um ideal admirável, tendo a única forma de excelência que uma ideia desse tipo pode ter: a excelência estética (SANTELLA, 1994, p. 188-189).

Peirce sabia que seria quase impossível descrever verbalmente a qualidade de uma experiência que não possuia nenhum traço de dualidade. Sabia que a "beleza" não poderia ser essa qualidade, pois o belo pressupõe necessariamente o seu contrário. Essa qualidade e essa experiência do admirável corresponderia justamente ao ideal em direção ao qual todo empenho ético deveria se dirigir (CURLEY, 1969).

Mediante este impasse, Peirce concluiu que o sentimento estético é um tipo misto de sentimento, localizado entre a mera qualidade do sentir e a atração intelectiva, um tipo de prazer produzido por uma "simpatia intelectual" (SANTAELLA, 1994).

Peirce chegou a conclusão que era coerente com as especificações da Estética e que tratava da questão do ideal supremo ou fim. Para que a função do signo 
fosse preenchida e para haver o crescimento da potencialidade da ideia, sua corporificação deveria se dar não apenas através de símbolos, mas também através de ações, hábitos e mudanças de hábitos. Na potencialidade, há primeiridade, na corporificação, há secundidade, e na ideia, há terceiridade. Os três juntos compõem o summum bonum (bem maior) estético, coincidente com o ideal pragmatista último: $o$ crescimento da razoabilidade concreta. Uma vez que a razão seria a única qualidade livremente desenvolvida através da atividade humana do autocontrole, Peirce identificou o ideal estético com o crescimento da razoabilidade concreta. Afirmava que não havia garantia de que o ideal estético-pragmático pudesse ser atingido, mas que sempre seria buscado. A palavra "concreta" indica que a razoabilidade pode ir se atualizando através do nosso empenho, sendo esse empenho um fator ético, meio pelo qual a meta do ideal estético admirável se materializa, do mesmo modo que a lógica é o meio através do qual a meta ética se corporifica (SANTAELLA, 1994).

Peirce acreditava que haveria uma verdade a ser conhecida e que nós seríamos participantes do desenvolvimento da razão em constante estado de incipiência e crescimento. A única coisa que seria desejável sem razão para o ser, o admirável sem razão ulterior, seria apresentar ideias e coisas razoáveis (BERNSTEIN, 1990).

Após a incessante busca pelo entendimento do papel da Estética em sua arquitetura filosófica, Peirce concluiu não ser ela meramente uma ciência do belo, encontrando sua essência em algo que poderia ser aproximadamente traduzido como “admirável”. Buscando o admirável, ele acabou por localizá-lo no crescimento da razoabilidade concreta, ou seja, na potencialidade da ideia.

A Estética de Peirce satisfaz quase à perfeição as metas de amalgamar razão e sentimento, conciliar os rigores do pensamento às liberdades do espírito, de integração do intelecto à Ética e à Estética, das contribuições do estético para o crescimento humano (SANTAELLA, 1994).

Peirce explicitou por meio de sua Filosofia que o ideal supremo ou fim residia na busca pelo conhecimento, pela razão. Mas, só buscaríamos deliberadamente conhecer e entender a "verdade" a respeito de algo que nos instigasse. Aquilo que é admirável, aprazível aos sentidos, que desponta sentimentos, independente de ser considerado belo ou não pelo senso comum, é o que desperta a atenção. Para Peirce (CP 5.113): “[...] é o prazer estético que nos interessa”.

A respeito da Estética de Peirce e sua relação com esta investigação, situada nas Ciências Biológicas, considera-se que a busca pelo conhecimento biológico é 
diretamente relacionada à capacidade de admirar e contemplar os seres vivos e os fenômenos naturais.

A relação do ser humano com a natureza não é somente uma relação de escolha. O ser humano não se volta à natureza apenas por vontade própria e nela tenta descobrir um mundo diferente do seu. Pelo contrário, ser humano e natureza estão conectados por elos inerentes à sua constituição (WANNER, 2010).

John Dewey (1859-1952) argumentava que qualquer experiência, incluindo a investigação científica, poderia ser estética na medida em que seria uma experiência, isto é, que se tratava de relação ativa entre o eu e o mundo (DEWEY, 1934). A partir dessa visão, explicita-se a relevância da Estética na Biologia, a despeito de, muitas vezes, não ser explorada e considerada nas discussões de investigação biológica.

Uma Teoria Estética é perfeitamente aplicável e relevante aos estudos da Biologia, buscando integrar a dimensão da afetividade, do encantamento, do âmbito de admirar, para assim, querer conhecer. Para o ser humano, os outros seres vivos e o ambiente natural são passíveis de causar admirabilidade e maravilhamento por ser algo que nos transcende e do qual nos sentimos, ou deveríamos sentir parte. No natural reside algo que é inefável. Nesse sentido, a apropriação de conceitos teóricos da Filosofia Peirceana que se relacionam com a natureza, comportamento, potenciais e limites dos signos mostra-se, nesse caso, válida. 


\section{CAPÍTULO 4. \\ O ENCANTAMENTO NO ENSINO}

"Entra em teu barco do devaneio, desatraca no lago de pensamento, e deixa o sopro do firmamento encher tua vela. Com teus olhos abertos, acorda para o que está à volta ou dentro de ti, e abre conversa contigo mesmo; pois assim é toda meditação."

Charles Sanders Peirce (CP 6.461) 


\subsection{A importância da Estética no Ensino de Ciências e Biologia}

Em sua teoria, Peirce apresentou uma visão que levava em conta o ser humano em todas as suas dimensões, o indivíduo em sua totalidade. Para Peirce, o ser humano, o objeto, e a representação não existiam de maneira isolada e direta. $\mathrm{Na}$ relação que o ser humano estabelece com o mundo existem vários fatores influenciadores. Essa relação envolve: os fenônemos ou objetos que podem se apresentar de diversas formas variadas; a nossa percepção por meio dos sentidos que podem ser estimulados de maneira singular, de acordo com o indivíduo; a nossa representação dos objetos ou fenômenos que não envolve somente a cognição, mas que pressupõe a influência dos valores éticos, e da nossa resposta estética, carregada de sentimentos e emoções.

Quando partimos para um contexto educacional, onde há uma relação entre professor e aluno e almeja-se que os alunos passem por um processo de construção do conhecimento e desenvolvimento de uma visão crítica de sua realidade, fica evidente a importância de se levar em consideração a totalidade do aluno como indivíduo. Com isso, agregar a dimensão Estética ao Ensino, trazendo a afetividade, a admiração, o encantamento, enfim, sentimentos nas suas mais variadas expressões, pode ser uma abordagem extremamente positiva no estímulo e na motivação do aluno na busca pelo conhecimento.

Claramente, o encantamento e a vontade de admirar deve ser parte da Educação de uma forma geral. Porém, quando levamos a discussão ao campo da Biologia, pode-se distinguir a potencialidade para se estimular os valores estéticos. A natureza é permeada de maravilhamento, favorecendo o despertar dos sentidos humanos uma forma natural. Muitas vezes, o distanciamento cada vez maior que o ser humano possui em relação à natureza pode abafar esse anseio por maravilhar-se com o natural. Dessa forma, um contexto educacional que estimula e resgata a admirabilidade que os seres vivos e a sua relação com o meio despertam, leva o aprendiz a querer se relacionar e conhecer cada vez mais a natureza.

Como exposto, a Estética permeia a vida humana e, definitivamente, a forma como nos relacionamos com o mundo é influenciada pelos valores estéticos estabelecidos a partir de nossa experiência e do contexto no qual estamos inseridos. A 
Estética está presente na Ciência e na forma como ela é construída.

No contexto científico da Biologia, uma pergunta ressalta a importância da Estética: “O que motiva os cientistas?”. Alguns exemplos podem ser citados na busca por uma resposta. Charles Robert Darwin (1809-1882) e Alfred Russel Wallace (18231913) possuíam o hábito de coletar besouros muito antes de refletir a respeito da origem das espécies divergentes. Edward Osborne Wilson (1929-1955) possuía grande afeição pela natureza e pelas formigas bem antes de tratar da Sociobiologia. Talvez os aspectos estéticos dos seres vivos sejam elementos importantes para motivar tanto a pesquisa biológica quanto o Ensino de Ciências (ALLCHIN, 2015).

As perspectivas estéticas ajudam a contextualizar os conceitos científicos e promovem a aprendizagem de uma forma mais significativa. Pode-se, certamente, explorar o maravilhamento de muitas maneiras. A partir de visitas ao jardim zoológico ou ao aquário, viagens de campo para parques locais, unidades de conservação, etc. Como alternativa, pode-se também trazer o mundo extraordinário para a sala de aula por meio de metodologias criativas. O encantamento importa para a Ciência e para o Ensino (ALLCHIN, 2015).

Em relação à Estética no Ensino de Biologia, nota-se que entender um pouco mais sobre o fenômeno da vida, sob um ponto de vista estético, poderia ser uma experiência marcante para todos aprendizes. No entanto, as situações que proporcionam um aprendizado considerando tais aspectos são muito raras. A Ciência, no interior da qual estão os fundamentos para entender a vida e toda a sua diversidade, apresenta-se muitas vezes, particularmente no âmbito do Ensino, como uma matéria complexa, descritiva, impessoal, abstrata e fragmentada. Ensinar Ciências Naturais ou Biologia requer mais do que aprender apenas conteúdos conceituais. É necessário também o conhecimento sobre o modo como os aprendizes atribuem os conceitos como o de biodiversidade, por exemplo, na formação de valores que irão nortear a vida prática (CAVASSAN; PINHEIRO; SENICIATO, 2006).

Em relação ao tratamento da Biodiversidade e o Ensino de Biologia, elementos estéticos são relevantes para que o processo ensino e aprendizagem possa se dar de maneira menos fragmentada e impessoal. Por meio da Filosofia Estética como embasamento e guia, busca-se então, uma aproximação do aluno em relação à ciência e a forma de estudá-la, e particularmente, aos modos e formas como se estuda o objeto 
natural.

Os professores de ciências desconhecem o papel importante que o maravilhamento possui nos processos de ensino e aprendizagem. Eles avidamente buscam fatos fascinantes para despertar o interesse dos alunos e abrir a porta para a aprendizagem da ciência. Na verdade, quando os professores são questionados, normalmente identificam que o seu maior desafio prático atual é, acima de tudo, tentar motivar os alunos descontentes de hoje. Para envolvê-los, alguns educadores defendem a integração Estética na educação científica de forma mais sistemática (FLANNERY, 1991, 1992, 1993;. GIROD et al., 2010 apud ALLCHIN, 2015).

Alguns trabalhos discorrem que em muitos momentos alunos e professores apontam a sala de aula como um ambiente entediante, sem muitos atrativos, já que raramente ocorre uma mudança de ambiente (SENICIATO \& CAVASSAN, 2004).

No caso de estudos em ambientes naturais, por exemplo, essa reflexão implica na maneira como o processo educativo contribuirá para a conduta dos indivíduos em relação à sua conservação. Se a experiência estética, caracterizada por essa aproximação entre o ser humano e o objeto natural, faz o ser humano refletir sobre si mesmo, o faz refletir, simultaneamente, sobre o objeto natural (SENICIATO; CAVASSAN; SILVA, 2006). Machado (1982) afirma que só cuidamos, respeitamos e preservamos aquilo que conhecemos e que a ignorância traz uma visão distorcida da realidade.

Tendo em vista uma relação dialógica entre professor e aluno nos processos de ensino e aprendizagem em diferentes níveis, cabe destacar o estudo do meio como alternativa. Este tipo de estratégia é caracterizado como sendo motivador aos alunos, pois propiciam momentos de estudo em situações extraclasse. Além disso, as aulas de Ciências Naturais e Biologia desenvolvidas em ambientes naturais têm sido apontadas como uma metodologia pertinente, tanto por envolverem e motivarem crianças e jovens nas atividades educativas, quanto por constituírem um instrumento de superação à fragmentação do conhecimento (BRASIL, 2002; SENICIATO \& CAVASSAN, 2004).

Especialmente no caso do Ensino de Biologia no nível superior, as aulas em ambientes naturais configuram-se como uma oportunidade peculiar para estudar os seres vivos em seu hábitat. Portanto, ressalta-se nesta investigação a importância em atentar à aula de campo como um espaço potencial para a exploração da Estética inerente aos 
objetos.

Parece ser indiscutível a importância que a motivação deve assumir na Educação. O ensino pautado somente nas idéias, no abstrato mundo dos conceitos e definições, tem contribuído para um desânimo, uma indiferença e um desprezo em relação ao conhecimento. O desenvolvimento das aulas de Biologia em um ecossistema terrestre natural favorece a manifestação de sensações e emoções nos alunos, as quais normalmente não se manifestariam durante as aulas teóricas (SENICIATO \& CAVASSAN, 2004).

No mundo humano, o desenvolvimento da inteligência é inseparável da afetividade. A afetividade pode asfixiar o conhecimento, mas pode também o fortalecer. Essa afirmação ressalta a importância do planejamento de aulas de campo, que não devem ser conduzidas somente pelo aspecto afetivo, sob pena de asfixiar o conhecimento (MORIN, 2001). A afetividade pode ser um ferramenta útil ao ensino, mas não uma finalidade por só. A afetividade deve estar associada ao conhecimento e à formação de valores.

\subsection{Uma Estética já tratada na Biologia}

Como explicitado nos capítulos anteriores, a Teoria de Peirce apresenta hipóteses que habitam o campo na generalidade. Ao propor uma teoria do pensamento, cabível a qualquer indivíduo, seus elementos e categorias deveriam ser gerais para que pudessem abarcar explicações do processo cognitivo de uma forma universalizada. Peirce não se preocupou em apresentar uma aplicação exata para sua Teoria.

Dessa forma, diversos estudiosos têm estudado suas ideias, utilizando-as em diferentes contextos por serem passíveis de aplicação nas distintas áreas do conhecimento. Entretando, o cuidado deve ser redobrado para que sua Teoria não seja utilizada levianamente, ou carregada de desencontros com as reais ideias do filósofo.

Mediante essa característica da teoria de Peirce, deparamo-nos com a grande dificuldade de partir de um panorama teórico-filosófico para uma aplicação no ensino, especificamente no Ensino de Biologia. Em busca de um norte, assumindo uma forma mais cautelosa de apropriarmo-nos da Teoria em questão, iniciamos uma busca por trabalhos de cientistas na área da Biologia que apresentassem certo diálogo com as 
ideias propostas por Peirce e que fosse mais palpavelmente aplicáveis.

Nessa busca, deparamo-nos com as ideias de Aldo Leopold. Considerado um clássico da literatura ambiental, A Sand County Almanac and Sketches Here and There (1949) (Figura 8), apresenta uma série de ensaios sob uma abordagem ecológica, tratando sobre a relação do ser humano com natureza, focando em uma abordagem estética aliada à conservação, trazendo ainda a questão da ética da terra. Dessa forma, partimos para uma análise mais específica da obra do autor, analisando sua relação com a Teoria de Peirce.

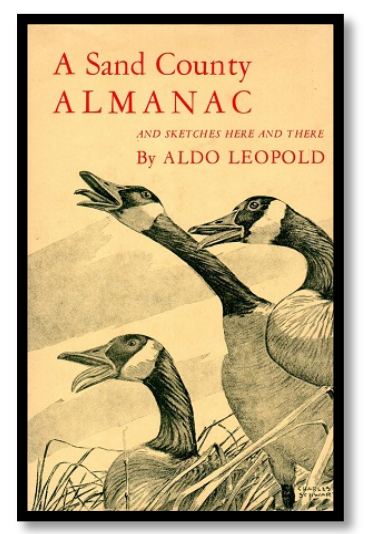

Figura 8. Livro de Aldo Leopold (1949) que trata da Estética da Conservação. Fonte: https://en.wikipedia.org/wiki/A_Sand_County_Almanac\#/media/File:Sand_county_almanac.jpg

\subsection{As ideias de Aldo Leopold sobre a estética da conservação e o diálogo com Peirce}

Aldo Leopold nasceu em 1887 em Burlington, Iowa, nos Estados Unidos. Leopold desenvolveu um interesse pelo mundo natural desde muito cedo, documentando e fazendo rascunhos dos elementos que encontrava no ambiente ao seu redor. Após se formar na Yale Forest School em 1909, trabalhou no Serviço de Floresta dos EUA. Em 1933 publicou seu primeiro livro didático no campo da gestão da vida selvagem. Em 1935, ele e sua família iniciaram sua própria experiência de restauração ecológica em uma fazenda ao longo do Rio Wisconsin. As consequentes mudanças observadas na flora e fauna da área foram documentadas e serviram de inspiração para 


\section{Leopold (THE ALDO LEOPOLD FOUNDATION, 2016).}

Leopold foi autor de diversos artigos científicos e jornalísticos, além de revistas populares. Além disso, o cientista dedicou-se a escrever um livro, voltado para o público em geral, que examinaria a relação da humanidade com o mundo natural. Infelizmente, apenas uma semana depois de receber a notícia que seu manuscrito seria publicado, Leopold faleceu de um ataque cardíaco em 21 de abril de 1948. Após sua morte, a coleção de ensaios escritos por Leopold foi publicado em 1949. Com mais de dois milhões de cópias vendidas, tornou-se um dos livros mais respeitados sobre o meio ambiente e a relação com o ser humano já publicado. Leopold passou a ser considerado por muitos como um pensador influente na área de conservação do meio ambiente. Hoje, o legado de Leopold continua a inspirar a enxergar o mundo natural como uma comunidade à qual pertencemos (THE ALDO LEOPOLD FOUNDATION, 2016).

$\mathrm{Na}$ terceira parte de seu livro, denominada "O desfecho", Leopold trata a respeito da estética da conservação e da ética da terra. Leopold (1949) entendia que a atração estética proporcionada pela natureza seria como uma poderosa força que precisava ser estimulada e canalizada com o fim de conservar o meio ambiente. Reforçava que uma aproximação do homem com a natureza seria ideal não apenas pela preservação e manutenção da estabilidade e integridade de uma comunidade biótica, mas também, pela beleza presente ali (FLANNERY, 1999). O cientista levava em consideração que a natureza possuía seu valor intrínseco e que também deveria ser preservada meramente por ser encantadora. O ser humano necessita do encanto.

Esta abordagem contrasta com a forma com que a relação da Estética e o mundo natural tem sido tratada, como já discutido anteriormente. Usualmente o belo na natureza é pouco trabalhado e ignorado (FLANNERY, 1999).

Segundo Leopold (1949), a nossa capacidade de perceber a qualidade na natureza começaria, como na arte, com o belo. Essa capacidade se expandiria através de nosso contato com os sucessivos estágios do belo, e assim, partiria para o âmbito dos valores, e posteriormente, esse processo acabaria captado sob a forma da linguagem.

Em nosso entendimento, ao Leopold envolver as questões do belo, dos valores e finalmente da formalização do pensamento sob a forma da linguagem, suas ideias dialogam estreitamente com as de Peirce, descritas em sua Teoria.

Claramente Peirce possuía uma abordagem voltada ao campo da Filosofia e 
do estudo do pensamento, uma visão estética mais aprofundada por não limitar a Estética ao belo, algo dotado de dualidade, mas por atingir algo mais basal. Para Peirce, a beleza em si acabaria por ser relativa de acordo com o indivíduo. No entanto, por conta de uma classificação de belo tanger algo que foi admirável por diversas pessoas a ponto de ser destacado como tal, e ainda o belo ser uma parte dentro da Estética, as ideias de Leopold e Peirce convergem, apesar de possuírem suas características próprias. Além disso, claramente, as esferas Estética e Ética interrelacionam-se em ambos autores. Mediante a abordagem de Leopold (1949) nos últimos capítulos de seu livro, podemos inferir que ele aceitava uma posição filosófica que relacionava a Estética e a Ética.

Em relação as ideias de Leopold (1949), de um modo geral, observa-se que as pessoas procuram os ambientes naturais por muitas razões e são muitas as maneiras de aproveitá-los. Consequentemente, existem muitas abordagens para a Estética da Conservação. Segundo Leopold (1949), existem diferentes níveis de resposta estética que o homem apresenta ao passar momentos de recreação em meio ao natural. Em seu livro apresentou cinco categorias que possuem abordagens diferentes e que variam de acordo com os efeitos causados pelo mundo natural (FLANNERY, 1999) As categorias da estética da conservação manifestadas no contato com a natureza são: troféu, isolamento, ar livre e mudança de panorama, percepção, sentido da administração cuidadosa (Quadro 2).

A primeira e mais simples categoria apresentada assenta-se na ideia do troféu, e reside no prazer da busca e na colheita. O troféu, seja ele um ovo de uma ave, um prato de trutas, cogumelos, a fotografia de um urso, o espécime esmagado de uma flor, ou o bilhete escondido num pico montanhoso, é um certificado que atesta seu proprietário ter estado em algum lugar e feito algo (LEOPOLD, 1949).

A experiência de estar em um ambiente que causou maravilhamento e levar algo consigo daquele lugar permite que as pessoas possuam um sentimento de propriedade - o indivíduo pode levar consigo algo que indique sua jornada em um ambiente prazeroso, um troféu (FLANNERY, 1999). As pessoas ao estarem em um local que se identificam, anseiam por ter algo provando de que estiveram ali e como uma forma de possuírem o ambiente e o momento vivido. Para muitas pessoas, a busca do troféu é o mais longe que sua apreciação à Terra pode chegar. 
A próxima categoria é a do isolamento, requer tempo e um sentimento de comunhão com a natureza. Leopold argumentou que nesta categoria, o sentimento de isolamento na natureza seria mais sutil e complexo do que buscar um troféu (LEOPOLD, 1949).

Muitas pessoas não apreciam a sensação de isolamento em meio à natureza, já que esta experiência é algo remoto em sua vida e causa desconforto e estranhamento. Esse tipo de apreciação leva tempo para se consolidar e requer que o indivíduo esteja disposto a se deixar envolver com o que está experienciando, tanto dentro de si mesmo como em relação ao ambiente natural. Com esse tipo de envolvimento, a apreciação estética do mundo macroscópico e microscópico muda, tornando-se não simplesmente um anseio de possuir o mundo por meio de coleções de troféus, mas de estar no mundo e sentir empatia por ele (LEOPOLD, 1949, FLANNERY, 1999). Seria a categoria na qual o indivíduo passa da fase de somente ter para deixar-se envolver com o ambiente.

A terceira categoria é ar livre e mudança de panorama. Para muitas pessoas, ter um contato com a natureza é algo realizado nos finais de semana ou férias, promovendo uma mudança do cotidiano, distanciamento do panorama urbano usual como forma de relaxamento (LEOPOLD, 1949; FLANNERY, 1999). Ou seja, além do indivíduo ter coletado troféus como uma forma de levar consigo aquele local e de ter se deixado isolar e envolver com o ambiente, ela começaria a relacionar o ambiente com sensações positivas de relaxamento e mudança do que usualmente está acostumado. Torna-se como um refúgio de descanso.

A quarta categoria apresentada é a da percepção. Essa categoria lida com a relação entre a experiência estética e o conhecimento. Envolve a ida a algum local com o fim de apreciar o mundo natural por meio de um aprendizado sobre ele. $\mathrm{O}$ aprendizado pode ser obtido por meio do contato com livros, mas é aprofundado por meio da observação e do envolvimento direto (LEOPOLD, 1949).

Nesta categoria, está explícita a conexão entre o conhecimento, a observação e a experiência estética. Por exemplo, as garças tornam-se mais interessantes quando o seu histórico evolutivo e sua ecologia são explorados. $\mathrm{O}$ conhecimento influencia a observação, e vice-versa, e aumenta a curiosidade de aprender mais. Passar tempo em meio a natureza pode provocar tanto a busca pelo conhecimento quanto a noção estética. Quanto mais uma pessoa conhece a respeito do 
ambiente natural, mais profundo o relacionamento com a natureza será (FLANNERY, 1999). Nesta categoria, fica claro o diálogo das ideias de Leopold com a ideias de Peirce a respeito da relação da Estética e o anseio pelo crescimento da razoabilidade concreta (descrito no Capítulo 3).

Finalmente, O sentido da administração cuidadosa é a quinta categoria estabelecida por Leopold na Estética da Conservação. Esta noção torna-se real quando a gestão e cuidado à terra consolida-se por uma pessoa que adquiriu conhecimento por meio da percepção (LEOPOLD, 1949). Quando um indivíduo se encanta, observa e compreende o meio, é mais provável que possua o desejo de conservá-lo, estando mais propenso a entender o que significa a conservação e como pode ser almejada e realizada. Neste ponto, a Estética, a Ética e a Lógica em Peirce integram-se mais claramente nas ideias de Leopold.

Passar tempo com a natureza e a busca por compreendê-la torna mais provável a admiração da natureza e o entendimento do seu valor (FLANNERY, 1999). Leopold entendia as cinco categorias da Estética da Conservação como uma progressão de uma visão rasa para uma visão mais rica e clara a respeito da natureza, sendo que nem todos passariam por todas as categorias e chegariam na última delas. Muitas vezes, a experiência em um ambiente natural limita-se meramente a uma experiência puramente estética, abragendo somente as primeiras categorias apresentadas. Quando tratamos de momentos voltados ao lazer e o divertimento, este tipo de experiência puramente estética não é considerada problemática. Entretanto, quando voltamo-nos a um contexto educacional, no qual o aluno visita um ambiente com o fim de estudá-lo e compreendê-lo, a experiência a ser proporcionada deve buscar uma integração dos âmbitos estéticos, éticos e lógicos, assim como é exposto nas categorias de Leopold (1949). 
Quadro 2. Categorias de Leopold (1949). A seta representa que essas categorias aparecem de uma forma crescente em nível de profundidade, sendo a categoria 5 a que exige um nível de profundidade maior na relação estética com o meio.

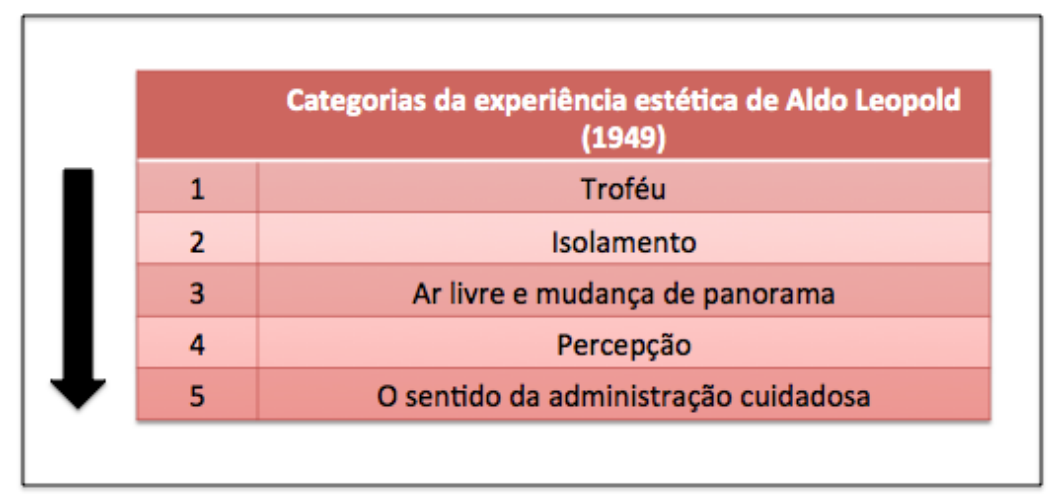

A Estética pode ser um caminho para enfatizar as experiências cognitivas e afetivas como relevantes no estudo dos ambientes naturais, pois a experiência estética deve ser participatória, engajando o intelecto e as emoções. Os biólogos tendem a desmerecer a Estética no ensino, assumindo que o encantamento em relação ao tema ensinado se tornará óbvio ao aluno ao familiarizar-se com o material. Além disso, os alunos usualmente sentem-se entediados com a quantidade de informação que mecanicamente devem aprender, obscurecendo o encanto inerente ao tema. Por o conhecimento e a sensibilidade estética estarem conectados, a beleza torna-se muito mais evidente com o entendimento mais aprofundado de uma determinada área do conhecimento (FLANNERY, 1999).

Na proposição da Sequência Didática (apresentada no Capítulo a seguir), adotaremos como metodologia à elaboração das aulas de campo não somente as ideias de Peirce sobre a Estética, mas também as categorias de Leopold apresentadas anteriormente. Estas categorias também serão utilizadas como fonte de análise dos dados obtidos na aplicação futura da Sequência Didática. 


\section{CAPÍTULO 5. \\ NAS TRILHAS DE SAINT-HILAIRE}

"There is pleasure in the pathless woods There is a rapture on the lonely shore; There is society, where none intrudes, By the deep sea, and music in its roar: I love not man the less, but Nature more..."” 


\subsection{Elaboração da sequência didática: nas trilhas de Saint-Hilaire}

Como já apresentado no Capítulo 2, investigamos quais estudiosos haviam explorado o ambiente da Serra da Canastra tendo os estudos do naturalista Auguste de Saint-Hilaire como pano de fundo à Sequência Didática. A trilha realizada por SaintHilaire apresenta-se como subsídio para que os alunos de cursos de Ciências Biológicas investiguem o ambiente da Serra da Canastra assim como o naturalista o fez, focando no Rio São Francisco e sua relação com os outros seres vivos existentes no seu entorno.

Para que pudéssemos adotar os relatos de Saint-Hilaire como pano de fundo da Sequência Didática, inicialmente, mostrou-se necessário que realizássemos uma pesquisa a respeito da vida do naturalista, para que, assim, não deslocássemos os relatos de seu livro do seu real contexto. Antes mesmo de tratarmos de Saint-Hilaire, mostra-se pertinente abordarmos a questão dos naturalistas viajantes de um modo geral.

Com o crescimento da curiosidade científica, no final do século XVII e começo do século XVII, o continente sul-americano começou a despertar interesse, não somente pelas suas infindas riquezas, mas também por interesses científicos. $\mathrm{Na}$ segunda metade do século XIX, o desenvolvimento das "Ciências da Natureza" e o conhecimento do Novo Mundo por viajantes e naturalistas começaram a se consolidar (LIMA, 2002).

Entre os séculos XVIII e XIX, muitos exploradores estavam dispostos a desbravar locais desconhecidos no mundo e o Brasil se tornou uma terra muito visada pelos viajantes. Além de ser uma terra ainda desconhecida, era um local muito atraente por possuir grande fonte de riquezas, despertando a curiosidade e interesse das potências européias (ECKARDT, 2009).

Como consequência da abertura dos portos brasileiros em 1808, tornou-se mais acessível aos estrangeiros a entrada no Brasil, servindo de impulso para que os viajantes, fossem naturalistas ou não, viessem ao Brasil com o objetivo de estudá-lo e explorá-lo. Dessa forma, inciou-se um período de grande fluxo de estrangeiros visitando nosso país, com o fim de descobrir suas riquezas naturais ou, no caso dos cientistas, simplesmente conhecer esta nova terra. Esse é o motivo de existirem muito mais relatos de viagens sobre o Brasil no século XIX do que em outros períodos da história (ECKARDT, 2009). 
Auguste de Saint-Hilaire (Augustin François César PROUVENSAL DE SAINT-HILAIRE) (Figura 9) nasceu em Orléans, em 1779, em uma família nobre. Em sua cidade natal, passou a juventude e estudou no Colégio de Pontlevez, dirigido pelos beneditinos de Solesmes. Posteriormente, viveu na Alemanha por algum tempo, e ao retornar à França, dedicou-se ao estudo da História Natural. Pertenceu à renomada congregação francesa de Saint-Cyr, conhecida e admirada pelos trabalhos de erudição e grande parte do conhecimento de Saint-Hilaire em diferentes áreas advém desse envolvimento. Em 1816, Saint-Hilaire partiu para o Brasil, na idade de trinta e sete anos. Nessa época, devido aos seus estudos prévios, possuía conhecimentos botânicos extensos, tendo publicado sobre a flora francesa, particularmente sobre a anatomia dos frutos. (KURY, 2003; LIMA, 2002).

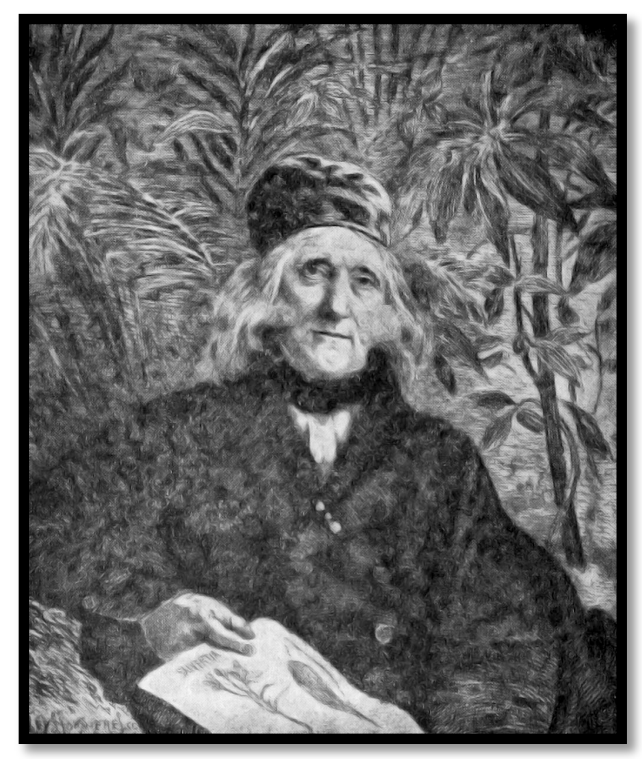

Figura 9. Retrato de Auguste de Saint-Hilaire (Augustin François César PROUVENSAL DE SAINT-HILAIRE). Fonte: https://commons.wikimedia.org/wiki/File:Auguste_de_SaintHilaire.jpg

Poucos detalhes foram estudados a respeito da vida e obra do naturalista viajante Auguste de Saint-Hilaire. Na França, muitas vezes, é considerado como um personagem esquecido. Porém, em sua época era reconhecido, tendo ocupado posição de prestígio no meio cientifico parisiense e francês (KURY, 2003).

A vocação para a botânica manifestou-se muito cedo na vida do naturalista. Dedicou-se, inicialmente, a Entomologia e a Botânica enquanto vivia na França. 
Contudo, em um determinado período, a fortuna de sua família foi prejudicada e ele passou a se dedicar ao comércio. Possuía repugnância por esse tipo de ocupação e a dificuldade em que foi forçado a viver fora de seu país de origem tornou a fase da juventude penosa. Nessa época, correspondeu-se com a Madame Genlis (1746-1830), que foi uma personagem marcante por seus conselhos que o motivaram a voltar aos trabalhos de Botânica (LIMA, 2002).

Ao retomar seus estudos em Botânica, limitava-se às plantas de seu meio mais próximo. Suas primeiras contribuições para a ciência foram no Bulletin de la Société des Sciences Physiques de Orléans, no Journal de Botanique de Desvaux, e no Bulletin de la Société Philomatique. Além disso, elaborou uma sequência de ensaios sobre Fisiologia vegetal. Além disso, Saint-Hilaire desenvolveu diversos outros trabalhos envolvendo o estudo da anatomia e dos orgãos reprodutores de plantas (LIMA, 2002).

Saint-Hilaire possuía grande interesse e curiosidade em conhecer outros países. Obteve a permissão do duque de Luxemburgo, embaixador no Rio de Janeiro, para realizar expedições. Viajou pelo Brasil por um grande período, de junho de 1816 a junho de 1822, pelas províncias do Rio de Janeiro, Espírito Santo, Minas Gerais, São Paulo, Goiás, Santa Catarina, Rio Grande do Sul e pela província Cisplatina. Ao retornar à França, publicou duas obras resultantes de sua experiência como viajante: Historie des plantes les plus remarquables du Brésil et du Paraguay (1824) (História das plantas mais notáveis do Brasil e do Paraguai) e Plantes usuelles des Brésiliens (1824-1828) (Plantas usuais dos brasileiros). Um ano depois começou a publicar a Flora Brasiliae Meridionalis (LIMA, 2002).

Saint-Hilaire era ligado aos aspectos filosóficos da História Natural e aos aspectos práticos de sua especialidade. Para ele, esses lados da ciência se complementavam e a vertente romântica da História Natural também seria uma ciência prática, voltada para a satisfação das necessidades das populações européias e para o fortalecimento material e simbólico de sua nação (KURY, 2003).

Uma característica do botânico, assim como de outros naturalistas viajantes, era que possuía a crença na permuta filantrópica, que na época significava um neologismo do século XVIII para descrever uma virtude natural do ser humano, o amor pelo próximo. A filantropia diz respeito à "humanidade", ou seja, as ações dos 
indivíduos em favor da sociedade são consideradas como um sentimento natural, pois a felicidade pessoal só é assegurada quando há a prosperidade social (KURY, 2003, p. 2).

A "biopirataria" exercida pelo viajante francês foi entendida e descrita como algo justificável mediante suas crenças por se tratar de uma troca e não de um roubo, sendo aceitável e benéfica à sociedade. Os elementos e conhecimentos sobre eles passariam a fazer parte do universo da ciência mundial, e não somente da França (KURY, 2003, p. 9).

A crença na filantropia permeava as atividades dos viajantes-naturalistas, e surgia a partir da distinção: países civilizados capazes de produzir "ciência" e países não totalmente civilizados, desempenhando práticas empíricas tradicionais. Para os naturalistas, em nome da ciência, as fronteiras nacionais deviam ser abolidas. A ciência deveria tornar-se universal. A filantropia nos fins do século XVIII e do século XIX, atuava no sentido de justificar as ambições nacionais e pessoais, aos olhos da elite européia. Ao levarmos em consideração essa troca filantrópica, podemos compreender a atitude dos naturalistas perante as populações locais dos países visitados. Os viajantes europeus que visitaram os países ditos "selvagens", sentiam-se portadores de uma espécie de missão, como no caso dos viajantes no Brasil (KURY, 2003, p. 2).

$\mathrm{Na}$ época da viagem de Saint-Hilaire, a divisão do reino vegetal era realizada em "famílias naturais", segundo o método Jussieu que permitia reconhecer parentescos morfológicos em plantas de países diferentes já que, a família de uma planta pode ser um possível indicador de suas propriedades. Segundo os padrões da época, o conhecimento universal de um viajante-naturalista poderia dizer mais sobre as plantas de um país desconhecido do que os conhecimentos populares de seus habitantes (KURY, 2003).

A viagem de Saint-Hilaire ao Brasil foi muito importante em sua vida e a maioria de suas publicações são resultado do período vivido no Brasil. Seus relatos da paisagem existente permitiram sua admissão na Academia de Ciências de Paris, em 1830. Quando Saint-Hilaire chegou às costas brasileiras, em 1816, o Brasil estava sob o jugo de Portugal. Os relatos de Saint-Hilaire são uma narrativa que iniciou-se seis anos antes da independência do Brasil, sendo uma importante fonte de referência da história do Brasil do século XIX (LIMA, 2002).

Nos seus relatos de viagem, nem sempre considerou o Brasil como um 
paraíso. Apresentou também uma visão crítica da sociedade brasileira. Denunciou os problemas das estruturas feudais, os abusos e a corrupção. Alguns trechos de seus relatos reconstituem cenas da vida cotidiana dos brasileiros. Sua obra é apreciada por diversos cidadãos brasileiros, especialmente os mineiros que receberam elogios de Saint-Hilaire. Os resultados das suas viagens foram particularmente importantes para a Botânica, pois ele descreveu novas espécies, gêneros e mesmo novas famílias. Contudo, uma doença adquirida, possivelmente antes de suas viagens, e as fadigas de sua viagem ao Brasil o debilitaram. Nos últimos anos de sua vida foi obrigado a interromper várias vezes o trabalho por causa de seus problemas de saúde (LIMA, 2002).

Os sentimentos patrióticos do botânico foram manifestados diversas vezes. Em diversos momentos estabeleceu contato com conhecidos na França com o objetivo de enviar espécies de plantas brasileiras para serem introduzidas em seu país. Sempre pensando na França, mostrou-se contente quando percorreu as regiões do Sul, de clima mais temperado. Em sua viagem, reconheceu algumas plantas de seu país e encontrou algumas espéceis que poderiam ser aclimatados na França, como o caso da araucária. Dessa forma, realizou diversos envios de sementes desta árvore para o Museu de Paris (KURY, 2003).

As viagens realizadas por Saint-Hilaire resultaram na coleta de cerca de 30 mil exemplares, dos quais entre seis e sete mil espécies foram de plantas. As amostras coletadas foram criteriosamente catalogadas e enumeradas nos cadernos de coletas de campo. As espécies estão descritas nos três volumes da obra Flora brasiliae meridionalis $(1825 ; 1829 ; 1832-1833)$ e os exemplares botânicos correspondentes estão depositados no Herbário de Paris do Muséum National d'Histoire Naturelle e da universidade de Montpellier e de Clermont-Ferrand na França (HERBÁRIO VIRTUAL A. DE SAINT-HILAIRE, 2016).

\subsection{Saint-Hilaire na Serra da Canastra}

O livro Viagem às Nascentes do Rio São Francisco (1937) apresenta os relatos de Saint-Hilaire sob a forma de um "diário de campo", usando uma linguagem repleta de descrições, sentimentos e impressões, tratando de sua expedição ao longo de grande parte da extensão do Rio São Francisco. Nele o autor descreveu a viagem pelo 
Rio de Janeiro, Ubá, o Caminho de Rio Preto, a entrada na Província de Minas Gerais pelo Rio Preto, os Campos a visita a São João del Rei e a Serra da Canastra, o quadro geral da região montanhosa e deserta, entre São João del Rei e a Serra da Canastra, a viagem de São João del Rei às nascentes do São Francisco, a Serra da Canastra e a Cachoeria Casca D’anta, a nascente do São Francisco, a Comarca de Paracatu, Araxás e suas águas minerais. A última parte do livro é dedicada à província de Goiás (Figura 10).

Em sua expedição, a distância média percorrida pelo naturalista e sua tropa, durante um dia, variava entre duas e três léguas, o que equivale a aproximadamente entre 12 e $18 \mathrm{~km}$. O percurso total realizado, ao longo da Estrada Real ou do Comércio, foi de aproximadamente 80 léguas, correspondente a $480 \mathrm{~km}$. Hoje, passando pelos mesmos lugares através de estradas atuais para automóveis, a distância entre Rio Preto e as nascentes do Rio São Francisco é de, aproximadamente, 650 km (LICCARDO \& MENDES, 2001).

A denominação da região como Serra da Canastra relaciona-se à tradição bandeirante de nomear os acidentes naturais como marcos sinalizadores dos seus roteiros. Canastra é um antigo vocábulo português de origem grega, utilizado para denominar um tipo de arca móvel, rústica, de formato retangular. Provavelmente a semelhança desse objeto com a forma da serra tenha sido o principal motivo da denominação do local. Auguste de Saint-Hilaire também citou a origem do topônimo canastra em seus relatos, atribuindo-o ao seu formato imponente, que julgava ter forma semelhante a um imenso cofre, afirmando que a serra deveria ter esse nome por ser comprida, lisa e arredondada em toda a extensão de seu topo (ICMBIO, 2005).

$\mathrm{Na}$ presente pesquisa, abordaremos a parte de sua trilha realizada na Serra da Canastra, focando nossa análise no capítulo X: A Serra da Canastra e a cascata denominada cachoeira da Casca-D'anta. Nascente do Rio S. Francisco (Figuras 10 e 11). 


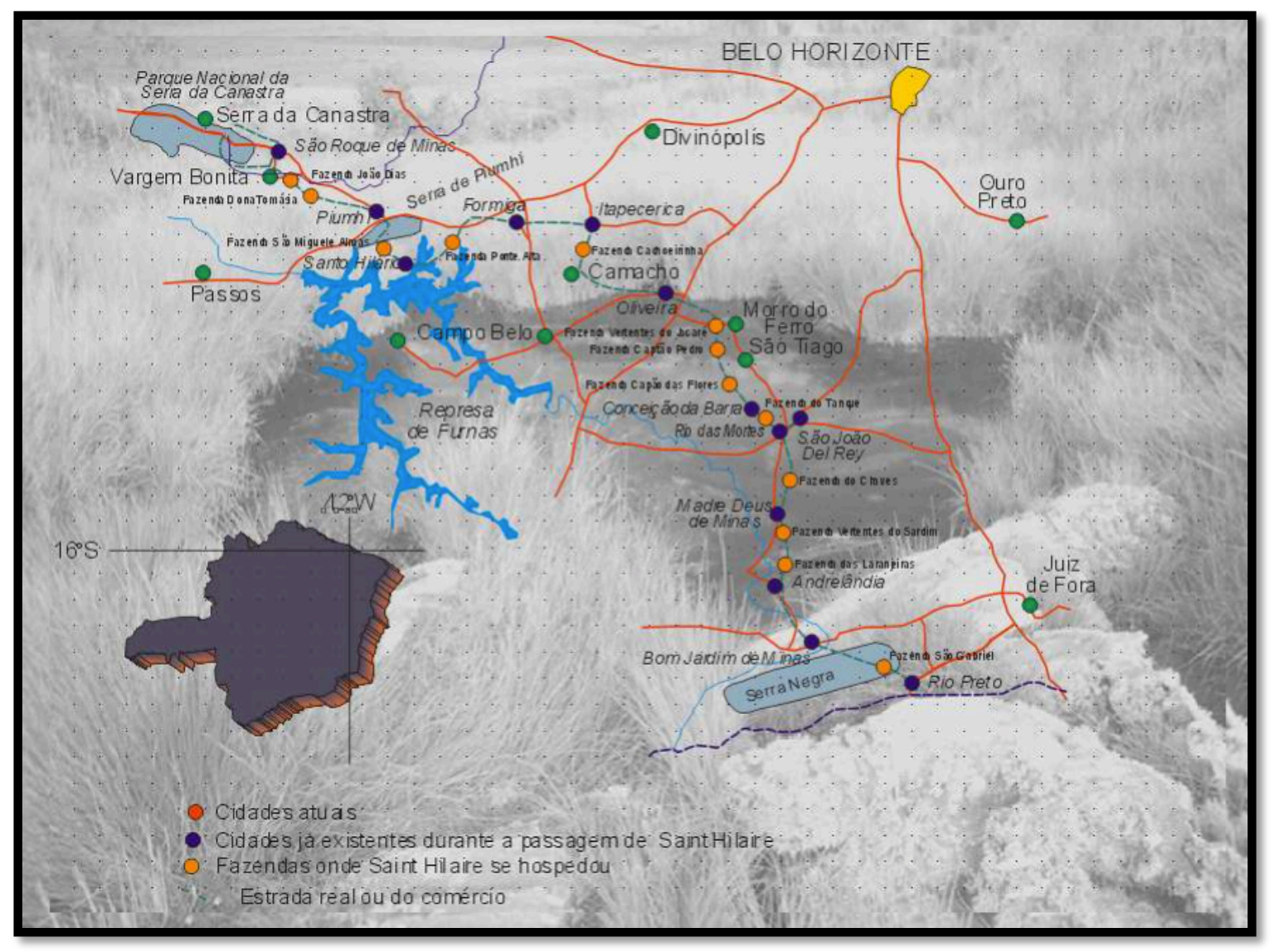

Figura 10. Mapa de toda a rota de Saint-Hilaire à margem do Rio São Francisco. Fonte: (LICCARDO \& MENDES, 2001). 


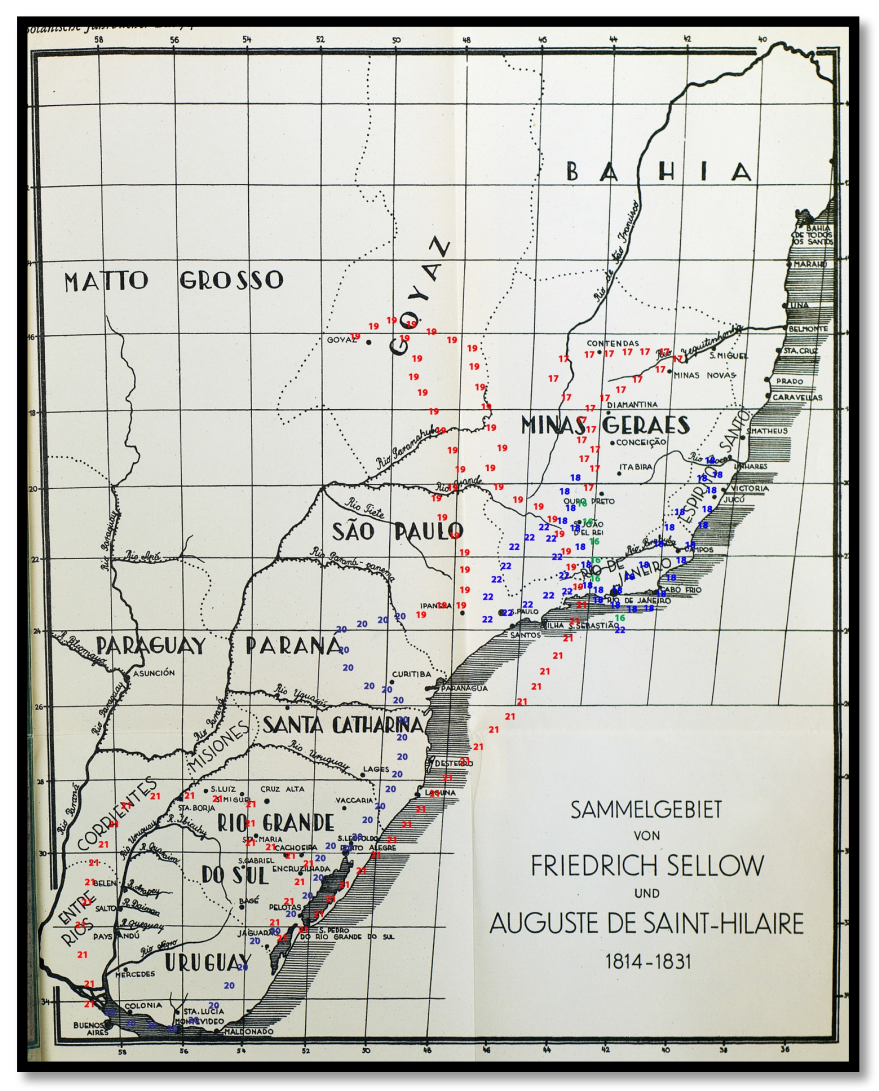

Figura 11. Mapa original contendo o trajeto percorrido pelo naturalista em sua expedição pelo Brasil. Fonte: Herbário virtual A. de Saint-Hilaire.

Há 200 anos atrás, época em que o naturalista esteve no Brasil, grande parte das cidades que encontramos hoje não existiam. Além disso, o Parque Nacional da Serra da Canastra não havia sido criado. Com isso, antes do naturalista chegar ao território atual do Parque, havia passado e se hospedado na cidade de Formiga. De longe fez uma descrição da fisionomia da Serra da Canastra, apresentando os mesmos aspectos que podemos notar atualmente ao aproximarmo-nos do local.

Antes mesmo de chegar a Formiga, eu já havia avistado no horizonte a Serra da Canastra. Essa montanha que, semelhante a um imenso cofre, mostra ao longe sua massa imponente, pareceu-nos tão isolada. Não é o que ocorre, porém. Ela faz parte da Serra das Vertentes, isto é, como se verá em breve, do planalto ou cadeia que limita a oeste a bacia do $\mathrm{S}$. Francisco (SAINT-HILAIRE, 1937, p.101).

O naturalista partiu rumo à Serra da Canastra com o intuito de encontrar uma cachoeria notável que tinha ouvido falar. $\mathrm{Na}$ época, a cachoeira não era bem conhecida pelas pessoas da região, sendo que as informações dadas a ele não eram 
precisas.

Desejando ver a cascata, deixei Firmiano e Laruotte na Fazenda da João Dias, com toda minha bagagem, e parti levando comigo apenas José Mariano. Saí convencido de que teria de percorrer apenas três léguas para chegar à cascata e que ela ficava localizada numa das montanhas vizinhas à serra (SAINT-HILAIRE, 1937, p.101).

O primeiro local citado como hospedagem para Saint-Hilaire e sua tropa foi a Fazenda João Dias, juntamente de José Mariano, companheiro que atuou como guia na região. A medida que se afastavam, o terreno apresentava um aspecto cada vez mais montanhoso. Ao longo do trajeto, o viajante apresentava suas impressões nos relatos acerca da paisagem.

Já tínhamos feito mais de três léguas sem que encontrássemos uma única habitação, embora não tivessem dito que haviam várias pelo caminho. Também não vimos viajantes e nem sinal de gado. Era uma bela solidão, mas uma solidão profunda. [...] Tínhamos já atravessado vários riachos de uma limpidez inigualável, entre eles o Ribeirão da Prata e o Ribeirão da Capivara, e durante o resto da viagem passamos ainda por outros, todos afluentes do S. Francisco (SAINT-HILAIRE, 1937, p.102).

Prosseguindo o caminho, percorreram cerca de quatro léguas até encontrarem as primeiras habitações. Nesse momento alcançaram o limite da Serra da Canastra e a Serra do Rio Grande.

Ao entrarmos no desfiladeiro a que já me referi vimo-nos muito próximos da serra. Ali o seu cume é perfeitamente regular, e grande parte dos seus flancos, nos pontos mais elevados, é formada de rochas talhadas a pique, cheias de sulcos e inacessíveis. Abaixo delas se estendem matas e pastagens naturais em encostas suaves, até o fundo de um vale estreito, onde corre o Rio S. Francisco. Embora as rochas formem como que um paredão quase vertical, elas estão longe de ser escalvadas, pois em vários pontos são cobertas por uma relva muito fina, que raramente deixa entrever a cor acizentada da pedra. Em nenhum outro lugar encontrei relvados de um verde tão bonito e tão viçoso como os que se estendiam aos pés dessas rochas a pique, e os matizes mais escuros das matas vizinhas não lhes ficava devendo nada em beleza (SAINT-HILAIRE, 1937, p.104).

Após atravessarem uma mata, chegaram à Casa do Felisberto, local onde iriam se hospedar com a finalidade de buscar a cachoeira Casca D'anta. Felisberto era um lavrador que morava perto da cachoeira e que se prontificou a levá-lo ao pé da 
queda d'água no dia seguinte. Assim que o naturalista pôde ver a cachoeira, destrinchou suas impressões a respeito.

\begin{abstract}
Embrenhamo-nos na mata e dentro de pouco começamos a ouvir o barulho da cachoeira. Pelas informações que me tinham dado havia poucos instantes, eu sabia que ela se despencava do lado meridional da Serra da Canastra. De repente, avistei o seu começo e logo em seguida pude vê-la em toda a sua extensão, ou pelo menos o máximo que podia ser visto do ponto onde nos achávamos. O espetáculo arrancou de José Mariano e de mim um grito de admiração. No ponto onde a água cai há uma depressão no cume do paredão de rochas, formando um sulco largo e profundo que vai descendo em ziguezague até uns dois terços da altura da pedreira, segundo nos pareceu. De um ponto ainda bastante elevado, onde termina a fenda, despeja-se majestosamente uma Cortina de água. O terreno que se estende abaixo da cascata é bastante irregular, e um outeiro coberto de verdejante relva esconde a parte inferior da Cortina de água. Do lado direito até ela uma mata de verde sombrio. É essa a nascente do S. Francisco (SAINT-HILAIRE, 1937, p.103).
\end{abstract}

Segundo seus relatos, durante a noite em que passou na Casa de Felisberto podia avistar, sob a luz da lua, a cachoeira de longe pela janela. O naturalista expressou sua gratidão pelo seu anfitrião por tê-lo hospedado em sua casa humilde com todo seu coração. Como forma de gratidão escreveu:

Felisberto, se ainda estiver vivo, já não deve mais se lembrar do estrangeiro que um dial lhe foi pedir abrigo. Quanto a mim, ainda o vejo sentado num banco de madeira, num cômodo escuro e sem móveis, e me parece ouvi-lo contar com calma as afrontas e vexames de que tinha sido vítima. Os exemplos de honestidade e de virtude não são tão comuns para que possamos esquecê-los facilmente (SAINT-HILAIRE, 1937, p.104).

No dia seguinte, Felisberto não pôde acompanhá-los até a cachoeira por causa de seus afazeres e Saint-Hilaire, José Mariano e José Lopes, sogro de Felisberto, partiram para a trilha rumo à Casca D'anta. Prosseguiram em uma trilha mais aberta, passando por diversas paisagens até chegarem às margens do São Francisco. SaintHilaire afirmou que o local onde pararam ficava mais ou menos a meia légua de distância de sua nascente. Finalmente, depois de uma caminhada penosa, chegaram ao pé da cachoeira.

O que foi visto pelo naturalista viajante foi ricamente descrito:

Acima dela vê-se, como já disse, uma larga fenda na rocha. No ponto onde caem as águas, as pedras formam uma concavidade pouco 
pronunciada. Da casa de Felisberto, a cachoeira me pareceu ter apenas um terço da altura das rochas, mas após tê-la observado de diversos ângulos creio poder afirmar que sua extensão é de dois terços dessa altura. Não a medi, (...), ela deve ter uns 203 metros, aproximadamente. Ela não se precipita das rochas com violência, exibindo, pelo contrário, um belo lençol de água branca e espumosa que se expande lentamente e parece formado por grandes flocos de neve. As águas caem numa bacia semicircular, rodeada de pedras amontoadas desordenadamente, de onde descem por uma encosta escarpada para formar o famoso Rio S. Francisco. (...) Dos dois lados da cachoeira as rochas são permanentemente úmidas e, embora talhadas a pique, mostram-se cobertas por uma relva muito verde e fina, que raramente deixa entrever a cor acizentada da pedra. Abaixo das rochas o terreno vai em declive até o rio, e no trecho mais próximo da cachoeira sua vegetação é composta só de arbustos. Mais adiante, porém, ele já se apresenta coberto de densas matas, onde se vêem numerosas palmeiras de troncos delgados e pequena altura. O verdor das plantas é de um viço extraordinário, que a proximidade das águas se encarrega de conservar. (...) Para se ter uma ideia de como é fascinante a paisagem ali, o leitor deve imaginar estar vendo em conjunto tudo o que a Natureza tem de mais encantador: um céu de um azul puríssimo, montanhas coroadas de rochas, uma cachoeira majetosa, águas de uma limpidez sem par, o verde cintilante das folhagens e, finalmente, as matas virgens, que exibem todos os tipos de vegetação tropical (SAINT-HILAIRE, 1937, p.105).

Após a experiência na Casca D'anta, o naturalista e seus acompanhantes voltaram à casa da Felisberto. Depois de jantarem juntos, o naturalista partiu novamente rumo à Fazenda de João Dias pelo mesmo caminho já percorrido. Ao longo do caminho, observou as habitações que encontrou e afirmou que os escassos moradores da região cultivavam a terra com as próprias mãos, e que seus produtos acabavam não tendo nenhuma saída. Para ele, somente a atividade de gado seria geradora de renda para os habitantes.

O naturalista esperava encontrar animais em meio às vegetações ao longo de seu caminho. Porém, afirmou não ter visto nenhum, alegando que um dos motivos para essa inexistência de animais seria que os habitantes passavam a maior parte de seu tempo caçando pelas redondezas. Da Fazenda João Dias, o naturalista continuou sua trilha rumo ao Chapadão. No caminho passou pela Capela de São Roque, sendo recepcionado por um padre. Saint-Hilaire (1937, p.106) descreveu a Capela como: “[...] feita de madeira e barro, com paredes sem reboco e seu estado era miserável”.

Após passar pela Capela, chegou em seu próximo local de hospedagem, a Fazenda do Geraldo. O naturalista e seus acompanhantes deixaram seus pertences na 
Fazenda e partiram para a trilha subindo a Serra da Canastra. Ao chegarem no Chapadão, Saint-Hilare descreveu:

Em toda extensão se seu cume a serra apresenta um vasto planalto irregular, que os habitantes da região chamam de Chapadão. Dali pude descortinar a mais vasta extensão de terras que meus olhos já viram desde que nasci. Num lado a Serra de Pium-i limitava o horizonte, mas em todo o resto unicamente a fraqueza de meus olhos restringia o meu campo de visão. Não se avistava um único povoado, uma única propriedade, nada que pudesse prender o olhar. Por toda parte as terras se estendiam em infinitas ondulações, em que pastagens e capões se alternavam. (...) O Chapadão é totalmente despovoado e sem cultivo. Suas terras nem mesmo tem dono (1819), mas os proprietários das fazendas localizadas na base da montanha levam seus animais para pastarem ali (SAINT-HILAIRE, 1937, p.108).

O naturalista ressaltou a questão da relação entre a água e a vegetação existente. Afirmou que sempre quando pudéssemos encontrar um filete de água correndo por um trecho, ali encontraríamos uma vegetação mais vistosa, e em locais com acúmulo de água poder-se-ia até encontrar pequenos grupos de árvores. Enquanto estava no planalto, Saint-Hilaire atentou-se em suas descrições à variedade de plantas que encontrou ao longo do caminho:

Os pontos mais elevados do planalto - pelo menos os que vi - não apresentam senão amonteados de pedras, no meio das quais proliferam várias espécies de canela-de-ema (Vellozia) e a Composta n. 372. Os lugares mais baixos são cobertos de capim, que ora é alto, ora é rasteiro, às vezes ralo, às vezes espresso, conforme a proporção em que a terra vegetal é se acha misturada com a areia (SAINT-HILAIRE, 1937, p.108).

Provavelmente, os números que acompanhavam as descrições das plantas apresentadas por Saint-Hilaire referem-se ao número de coleta da planta de acordo com seu registro e método de catalogação, como expresso:

À exceção da Serra Negra, não vi nenhuma outra parte uma variedade tão grande de plantas quanto na Serra da Canastra. A família prodominante é a das Compostas. As Euriocauláceas crescem também ali em abundância, já que o terreno, composto de uma mistura de areia branca e terra vegetal preta é o que as plantas preferem. A Gencianácea n. 575, a Convolvulácea n. 379 e as Escrofulariáceas n. 377 e 391 são também muito comuns nas campinas do planalto. Quanto às Melastomáceas, tão abundantes em outras serras, suas variedades ali se restringem a seis espécies. Aliás, em pouco tempo recolhi cinquenta 
espécies de plantas que ainda não tinha visto nessa viagem, sendo que várias eram pra mim inteiramente desconhecidas (SAINT-HILAIRE, 1937, p.108).

Saint-Hilaire seguiu seu caminho descendo a Serra rumo ao seu próximo lugar de hospedagem, a Fazenda do Geraldo. No caminho o naturalista continuou com suas descrições a respeito da paisagem e dos seres vivos encontrados.

Enquanto descia a serra eu usufruía, encantado, as belezas da paisagem. O tempo estava fresco, e nuvens brancas e esgarçadas deslizavam celeremente pelo céu, que era de um azul sereno, um pouco mais vivo, porém, do que o do norte da França durante os belos dias de outono. Aquela alternância de matas e campinas, a diversidade de cores que disso resultava e o contraste entre a planície e a montanha produziam um efeito encantador. Durante todo o dia, o único animal que encontrei foi um macaco. Como já disse, os habitantes do sertão são todos caçadores entusiatas, matando qualquer animal cuja pele possa ser objeto de comércio. Não passei por uma única propriedade que não contasse com numerosos cães de caça (SAINT-HILAIRE, 1937, p.108).

Após se hospedar na Fazenda do Geraldo, o naturalista e sua tropa partiram rumo ao Arraial de Araxá, passando pela Fazenda de Manuel Antônio Simões. No caminho descreveu algumas espécies de plantas que encontrou no caminho.

A região que percorri entre a Fazenda do Geraldo e a de Manuel Antônio Simões é montanhosa, com as mesmas alterâncias de matas e capinzais de um verde belíssimo. As flores eram pouco numerosas, mas numa das campinas que atravessei vi algumas encantadoras: uma bonita mimosa (n. 411), uma bela Gencianácea de flores azuis (n. 206) e uma Malpiguiácea de flores cor-de-rosa (n. 117) (SAINT-HILAIRE, 1937, p.109).

Rumo à Araxá, o próximo ponto da trilha evidente é a Cachoeira do Rolim, também descrita cuidadosamente pelo naturalista. E assim, ele prosseguiu seu caminho seguindo as nascentes que desembocam no Rio São Francisco. Saint-Hilaire (1937, p.110) afirmou: "Enquanto tive diante dos meus olhos a Serra da Canastra desfrutei de um panorama maravilhoso".

\subsection{Resgatando a trilha de Saint-Hilaire na Serra da Canastra}

Como apresentado na metodologia (Capítulo 2), foi realizada uma expedição à Serra da Canastra no período de 24 a 26 de agosto de 2016 para mapear e 
revisitar alguns pontos que o naturalista viajante Auguste de Saint-Hilaire passou e descreveu em seus relatos.

Mediante os relatos do naturalista e a viagem de coleta de dados, mapeamos os locais visitados pelo naturalista na Serra da Canastra, sendo eles: Fazenda João Dias, Casa do Felisberto, Cachoeira Casca D'anta, Nascente do Rio São Francisco, Capela de São Roque, Chapadão, Fazendo do Geraldo, e Cachoeira do Rolim (Figura 12). 


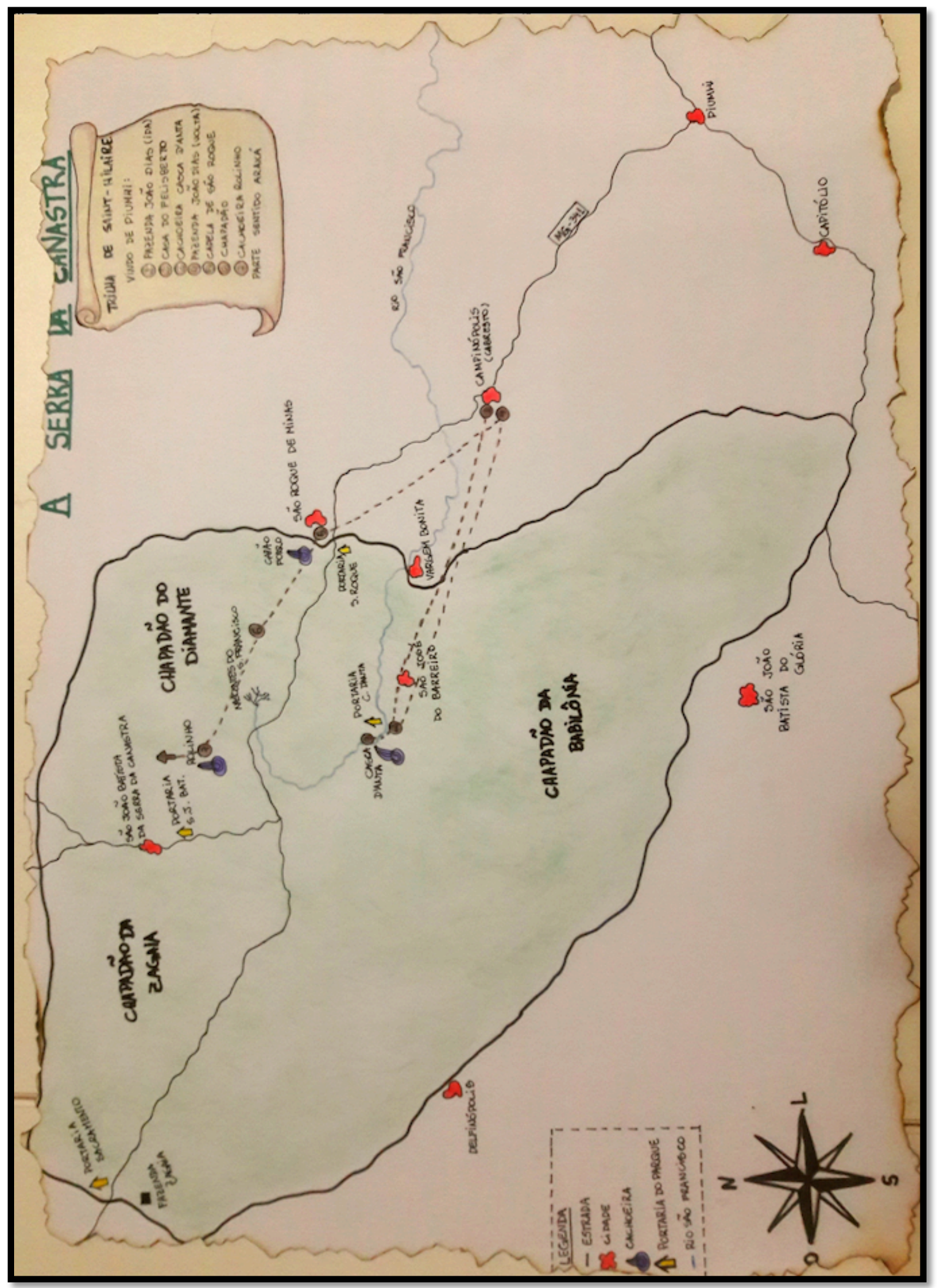

Figura 12. Mapa da região da Serra da Canastra contendo os pontos da trilha realizada por Saint-Hilaire, e os locais relevantes à Sequência Didática. Fonte: autora. 
Com o objetivo de encontrar cada um desses pontos descritos no relato de Saint-Hilaire, além de observar o que foi descrito por ele, fizemos uma busca por materiais disponíveis que facilitassem a localização de cada um desses locais. Porém, poucas informações foram encontradas. Com isso, direcionamo-nos à cidade de São Roque de Minas - MG com o intuito de buscar informações com os próprios moradores da região a respeito da passagem de Saint-Hilaire.

$\mathrm{Na}$ busca por informações, diversos moradores foram entrevistados informalmente. Entretanto, dois personagens locais foram muito importantes para o resgate da trilha realizada por Saint-Hilaire: Ulisses Florencio Seabra, residente em Campinópolis, e Antônio Francisco de Faria, residente em São Roque de Minas. Portanto, grande parte das informações que serão apresentadas são oriundas do conhecimento popular dos moradores da região da Serra da Canastra.

\subsubsection{A Fazenda João Dias}

Saint-Hilaire e sua tropa delocaram-se da cidade de Formiga, existente atualmente, mas provavelmente com proporções bem maiores, deslocando-se pela Estrada Real, que eram estradas públicas antigas existentes nos séculos XVII, XVIII e XIX, administradas pelo Governo Português, rumo à Fazenda João Dias (Figura 12).

Atualmente, a antiga Fazenda João Dias pertence ao município de Campinópolis - MG, cidade vizinha de Formiga. Segundo relatos dos moradores, a cidade de Campinópolis era chamada de Cabresto, sendo que até hoje muitos ainda consideram este nome como sendo o original. A Fazenda onde Saint-Hilaire se hospedou era conhecida por comercializar cabrestos e outros objetos utilizados em arreio para prender o animal ou para controlar sua marcha a viajantes que passam, e devido a fama obtida pelos objetos vendidos na região, a pequena vila acabou sendo denominada com o nome de Cabresto.

João Dias era um coronel que manufaturava em sua Fazenda diversos objetos, transformando o local em um pequeno centro comercial. As construções que encontramos na Fazenda são todas atuais, porém, hoje ainda é possível encontrar vestígios de um moinho de fubá utilizado na época em que Saint-Hilaire se hospedou na 
Fazenda (Figura 13).

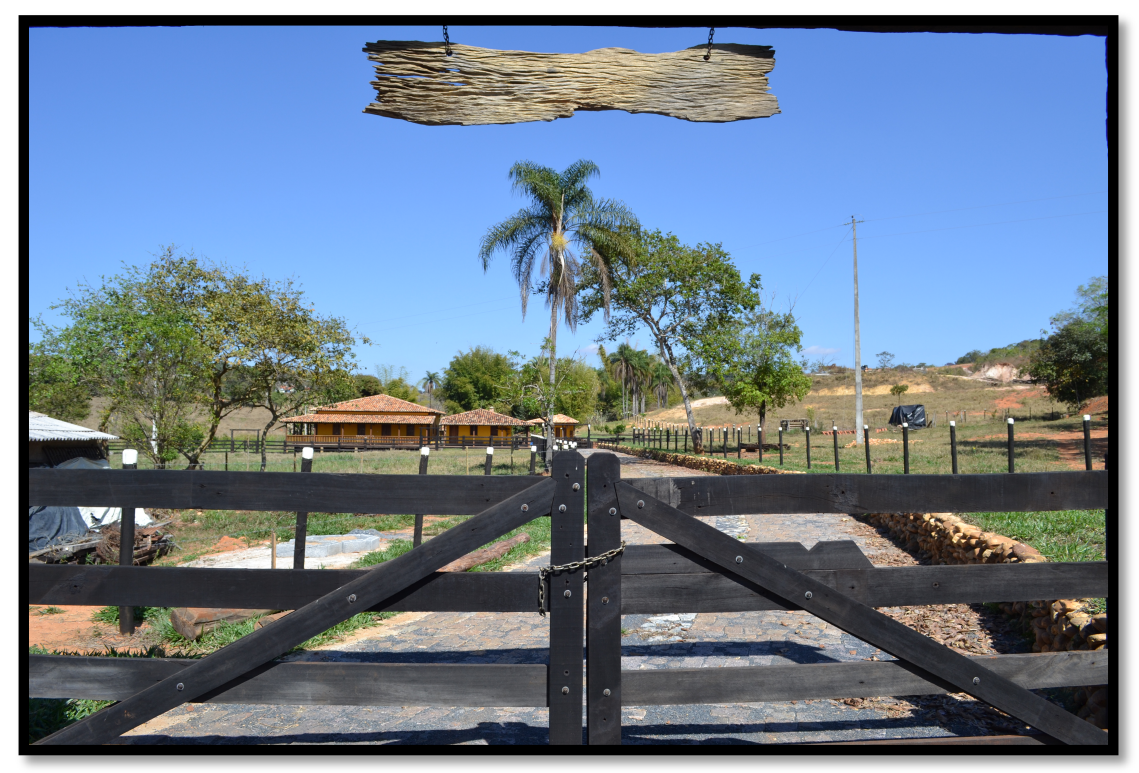

Figura 13. Foto da antiga Fazenda João Dias. Fonte: autora.

\subsubsection{Casa do Felisberto}

Segundo relatos dos moradores da região, a antiga casa de Felisberto encontra-se próxima à parte baixa da cachoeria Casca D'anta, localizada hoje no atual município de São João do Barreiro - MG. Em nossa expedição pudemos encontrar a possível casa (Figura 14) que corresponde à de Felisberto mas, provavelmente, tenha sido reconstruída. Atualmente a casa pertence à área do Parque Nacional na Serra da Canastra, próxima à Portaria Casca d'Anta (Portaria IV).

Possivelmente, a casa encontrada foi onde Saint-Hilaire avistou pela primeira vez a cachoeira que tanto buscava e de onde teceu uma série de descrições enquanto observava o cenário à luz da lua. Atualmente, não é possível avistar a cachoeira a partir da localidade da casa devido à vegetação alta e densa que bloqueia a vista. Provavelmente a vegetação tenho sofrido mudanças desde a época que o naturalista se hospedou na casa até os dias atuais.

Desde a implantação do Parque, a vegetação deve ter sofrido grandes mudanças na região. Fazendas, cuja principal atividade era a pecuária extensiva, 
ocupavam a região e contribuíram para a alteração das características originais da cobertura vegetal devido ao pisoteio do gado, incêndios e desmates para formação de pastagens e lavouras de subsistências, ou mesmo para instalação de infra-estruturas. Em 1819, Saint-Hilaire já relatava a ocorrência de fogo colocado por fazendeiros para renovação de pastagem (ICMBIO, 2005).

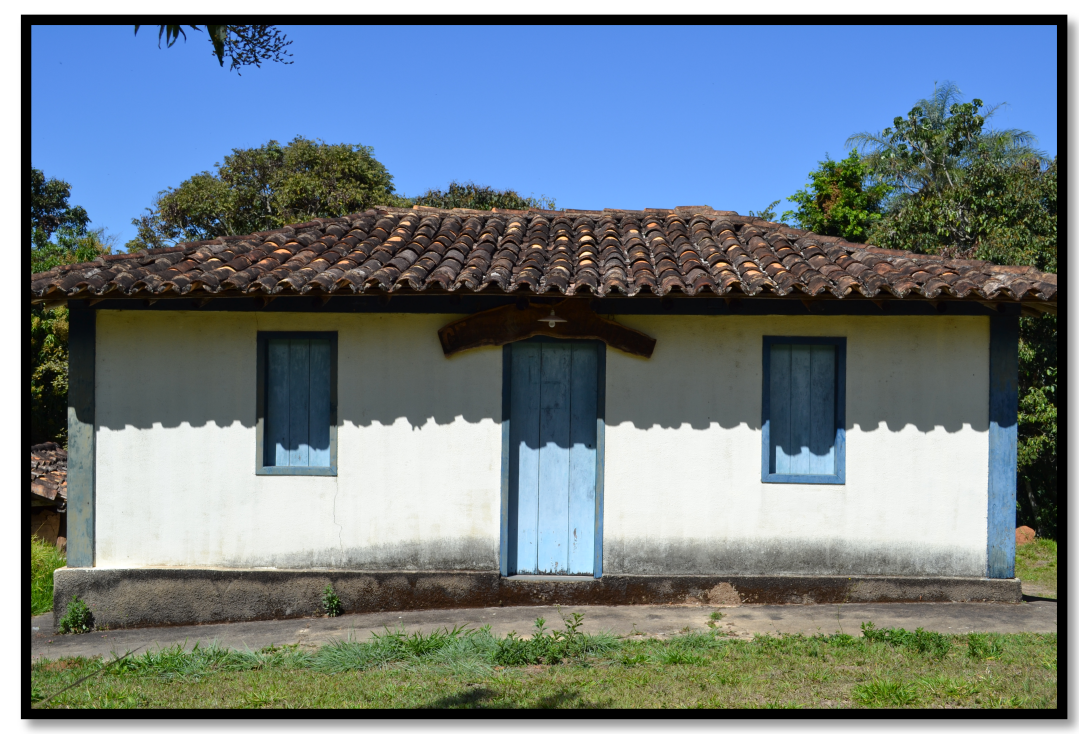

Figura 14. Foto da antiga casa do Felisberto. Fonte: autora.

\subsubsection{Cachoeira Casca D'anta (parte baixa)}

A Cachoeira Casca D’anta (Figura 15) é considerada como a maior queda d'agua do Rio São Francisco, possuindo uma altura de $186 \mathrm{~m}$. Seu nome é originário da árvore Casca D’Anta (Drimys winteri), planta que possui propriedades medicinais cicatrizantes. Segundo relatos, o animal anta possui o hábito de se esfregar no tronco desta árvore para curar ferimentos e, devido a grande presença da planta na região, a cachoeira foi nomeada em sua homenagem.

A fama e a beleza da cachoeira foi o que atraiu o naturalista Saint-Hilaire a direcionar-se à região. Assim, seu relato a respeito da vista da parte baixa da Casca D'anta apresentou uma séria de descrições impressionadas a respeito do que podia enxergar, como apresentado anteriormente neste capítulo. As impressões descritas em seu relato são facilmente identificáveis hoje ao se observar a grande queda d'agua.

Ao observarmos a vegetação do local próximo à cachoeira, encontramos na 
parte baixa uma vegetação característica de Cerradão. Esse tipo de vegetação é caracterizado pela presença de espécies que ocorrem no Cerrado sentido restrito e também por espécies de mata, apresentando dossel predominantemente contínuo. A altura média do estrato arbóreo varia de 8 a 15 metros, proporcionando condições de luminosidade que favorecem a formação de estratos arbustivos e herbáceos diferenciados (ICMBIO, 2005). Além disso, matas de galeria estão presentes próximas ao trajeto do rio. As características que pudemos notar em relação à região estão de acordo com a descrição de Saint-Hilaire em seus relatos: onde fosse possível encontrar uma certa concentração de água, ali estaria presente uma vegetação mais densa.

No caminho da trilha atual que permite o acesso das pessoas à cachoeira, nota-se a presença de uma grande variedade de plantas. Infelizmente, não foi possível encontrar a Drimys winteri, a planta casca d'anta, pertencente à família das Winteraceae, que suspostamente era vista em grande abundância.

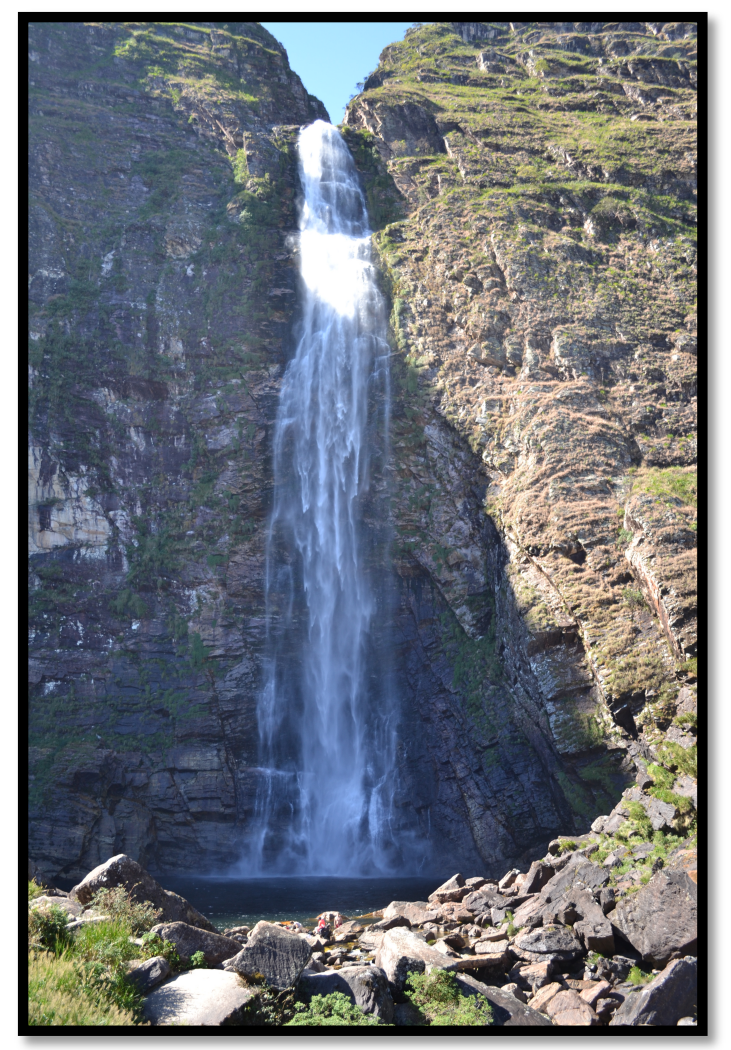

Figura 15. Foto frontal da cachoeira Casca D'anta na parte baixa. Fonte: autora. 


\subsubsection{Nascente do Rio São Francisco}

A região do Parque Nacional da Serra da Canastra abrange áreas de cabeceiras das bacias hidrográficas do Rio São Francisco e do Rio Paraná. Destaca-se uma densa rede de drenagem com inúmeros tributários e nascentes que alimentam os diversos cursos d'água. Na bacia do Rio São Francisco foram identificadas 15 subbacias. O Rio São Francisco pode ser considerado como um dos mais importantes cursos d'água do Brasil e da América do Sul. O rio passa por cinco estados e 521 municípios (ICMBIO, 2005).

Sabendo da importância do Rio São Francisco ao território brasileiro, SaintHilaire empreendeu sua jornada por toda sua extensão. Em seus relatos, no momento em que avistou a Casca D'anta e a descreveu, logo após relacionou que a nascente do rio estivesse ali próxima, no terreno que se extendia abaixo da parte inferior da queda d'agua.

Atualmente, foi estabelecido um local oficial para a nascente do Rio São Francisco, próximo à parte alta da Casca D’anta, no município de São Roque de Minas, centro-oeste de Minas Gerais (Figura 16). Entretando, discussões atuais alegam a dificuldade em se estabelecer quais são as reais nascentes de um rio, e que possivelmente, a nascente conhecida na serra da Canastra, seria somente histórica ou geográfica.

De acordo com Silva et al. (2003), a observação de diversas fontes de informação gera questionamentos sobre a relação hidrológica rio principal/afluente entre os rios São Francisco e Samburá. Nos arquivos digitais, pode-se observar que a bacia hidrográfica do Rio Samburá possui maior área geográfica do que a do São Francisco. Pelo critério de área da bacia hidrográfica, o Rio Samburá conteria, assim, as nascentes verdadeiras do São Francisco. Portanto, segundo os autores a verdadeira nascente do Rio São Francisco estaria no Planalto de Araxá, no município de Medeiros. 


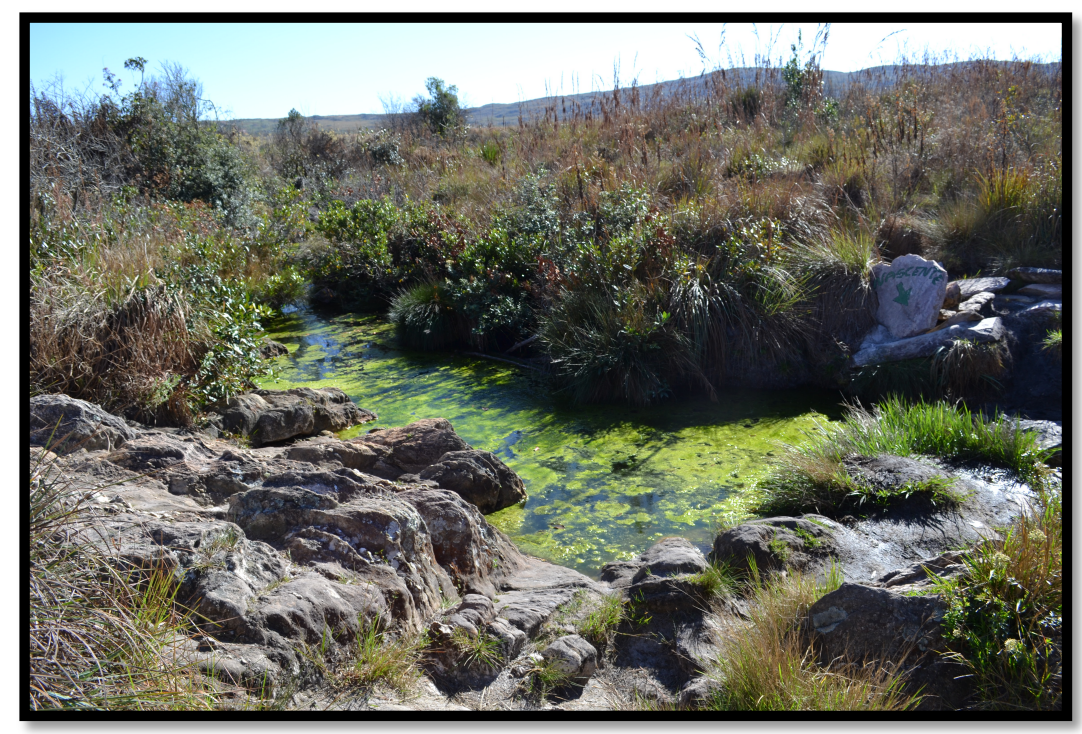

Figura 16. Foto da nascente simbólica do rio São Francisco. Fonte: autora.

\subsubsection{Capela de São Roque}

O próximo ponto de passagem de Saint-Hilaire, antes de chegar na Fazenda do Geraldo, foi a Capela de São Roque. Em 1762, foi construída uma capela em honra a São Roque, localizada no terreno da fazenda de propriedade de Manoel Marques de Carvalho, onde hoje denomina-se Capela Vellha. Posteriormente, a fazenda foi vendida a Belarmino Rodrigues de Melo, que doou as terras que vieram a formar o patrimônio da futura cidade de São Roque de Minas. O povoado tomou o nome de São Roque, em homenagem ao padroeiro.

Porém, a Capela Velha (Figura 17), local onde passa a estrada que conecta São Roque de Minas à cidade de Bambuí, visitada por Saint-Hilaire, foi demolida, e assim, construída uma nova igreja matriz (Figura 18) para a cidade de São Roque de Minas. A atual igreja matriz (Figura 19) já passou por reformas, sendo a última realizada em 2005. 


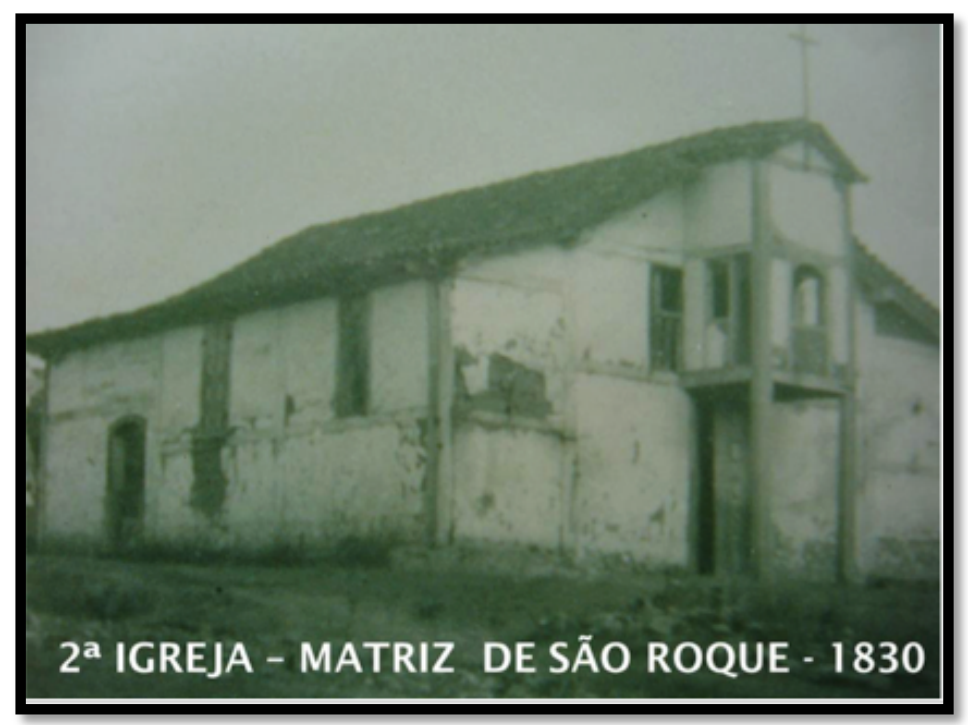

Figura 17. Foto da antiga capela de São Roque, denominada atualmente como Capela Velha. Fonte: arquivo de Antonio Francisco de Farias.

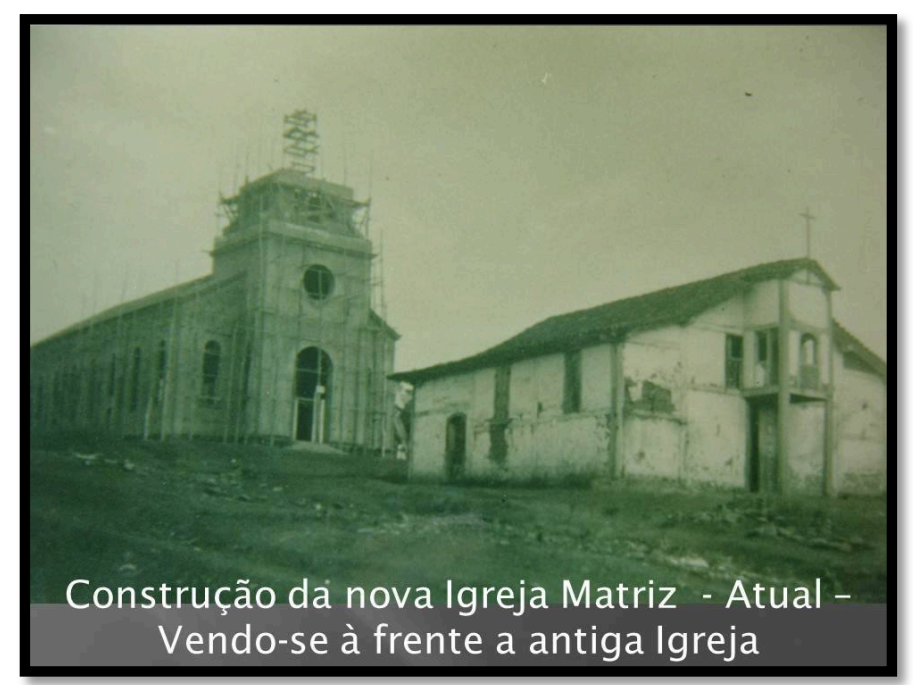

Figura 18. Foto da Capela Antiga e da nova matriz sendo construída. Fonte: arquivo de Antonio Francisco de Farias. 


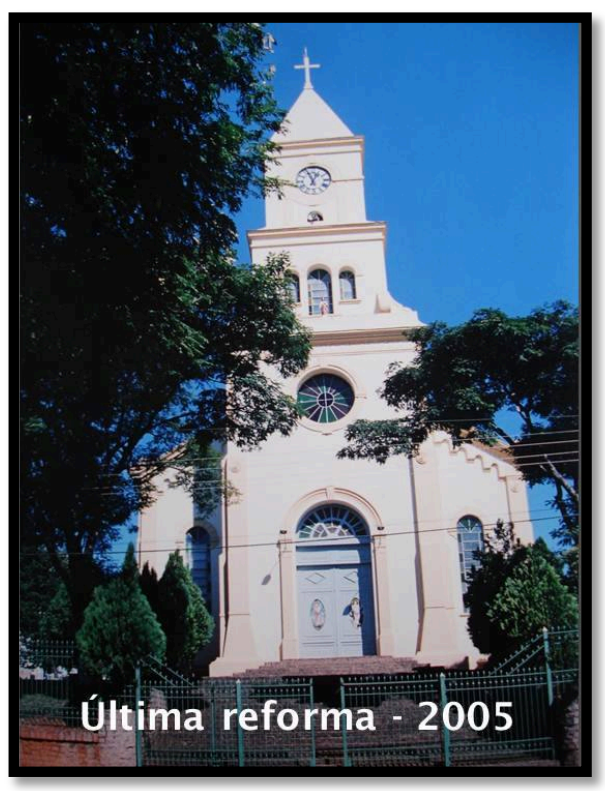

Figura 19. Foto da atual Igreja Matriz de São Roque de Minas. Fonte: arquivo de Antonio Francisco de Farias.

\subsubsection{Chapadão}

O campartimento do Chapadão é formado por três blocos rochosos de destacadas altitudes, denominados genericamente de chapadões e serras. A largura média estimada do conjunto rochoso é de $27 \mathrm{~km}$ (ICMBIO, 2005). O compartimento está subdividido da seguinte forma:

- Ao norte: bloco Canastra, abrangendo a chapada do Diamante e a chapada da Zagaia;

- Porção intermediária: bloco Babilônia, representado pelo Chapadão da Babilônia, abrangendo a serra das Sete Voltas e a serra do Cemitério;

- Ao sul: bloco Sul, abrangendo as serras dos Canteiros, Preta e Santa.

O topo dessas elevações rochosas é caracterizado por feições dos tipos superfícies aplainadas, vertentes ligeiramente inclinadas e cristas rochosas. As superfícies aplainadas encontram-se bem representadas nos chapadões do Diamante, Zagaia e Babilônia, onde predominam altitudes acima de $1.400 \mathrm{~m}$, podendo atingir $1.494 \mathrm{~m}$ (ICMBIO, 2005).

Em sua trilha, Saint-Hilaire chegou à região do Chapadão após ter passado 
pela parte baixa da Casca D'anta, descrevendo a respeito da paisagem que encontrou no local. Uma de suas primeiras impressões foi que o local era totalmente despovoado e sem cultivo. Atualmente, esse fator se mantém o mesmo, sendo possível notar a total ausências de pessoas principalmente devido ao fato do local ter se tornado parte da área do Parque Nacional.

As partes mais elevadas do plantalto encontradas pelo naturalista foram descritas como amontoados de pedras com algumas espécies proliferando-se nesse meio, destacando-se as canelas-de-ema. Atualmente, encontram-se 20 espécies na região, com flores brancas, roxas e lilás.

Em nossa passagem por partes do Chapadão da Canastra encontramos com grande facilidade uma considerável concentração de espécimes da planta canela-de-ema (Vellozia squamata) pertencente à família Velloziaceae (Figura 20). Posteriormente à expedição realizada, foi possível encontrar alguns dos registros de coleta realizados pelo naturalista, como no caso da canela-de-ema (Figura 21), e diversas outras espécies descritas por ele em seus relatos.
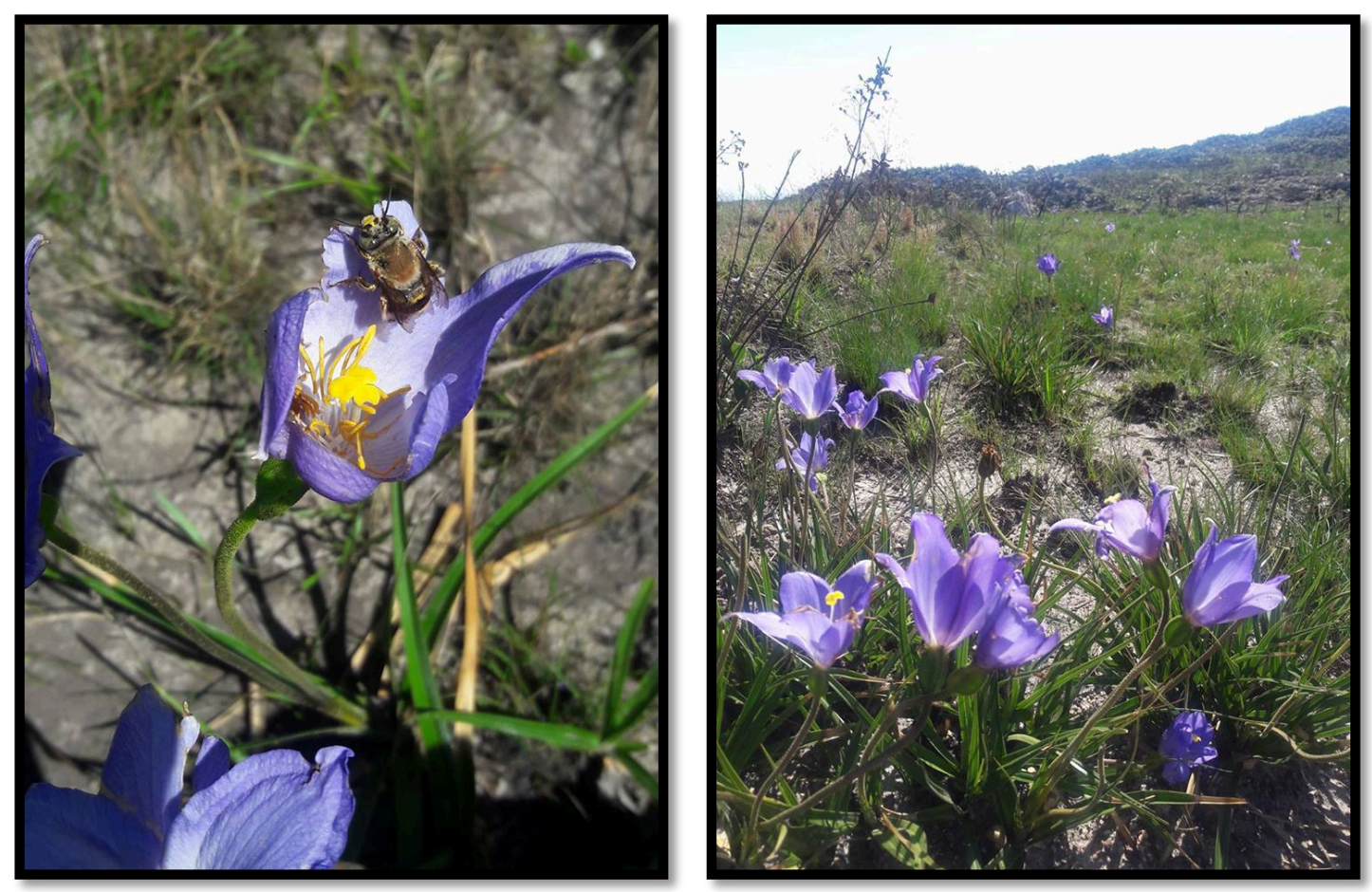

Figura 20. Fotos da canela-de-ema (Vellozia squamata) encontradas no Chapadão da Canastra. Fonte: autora 


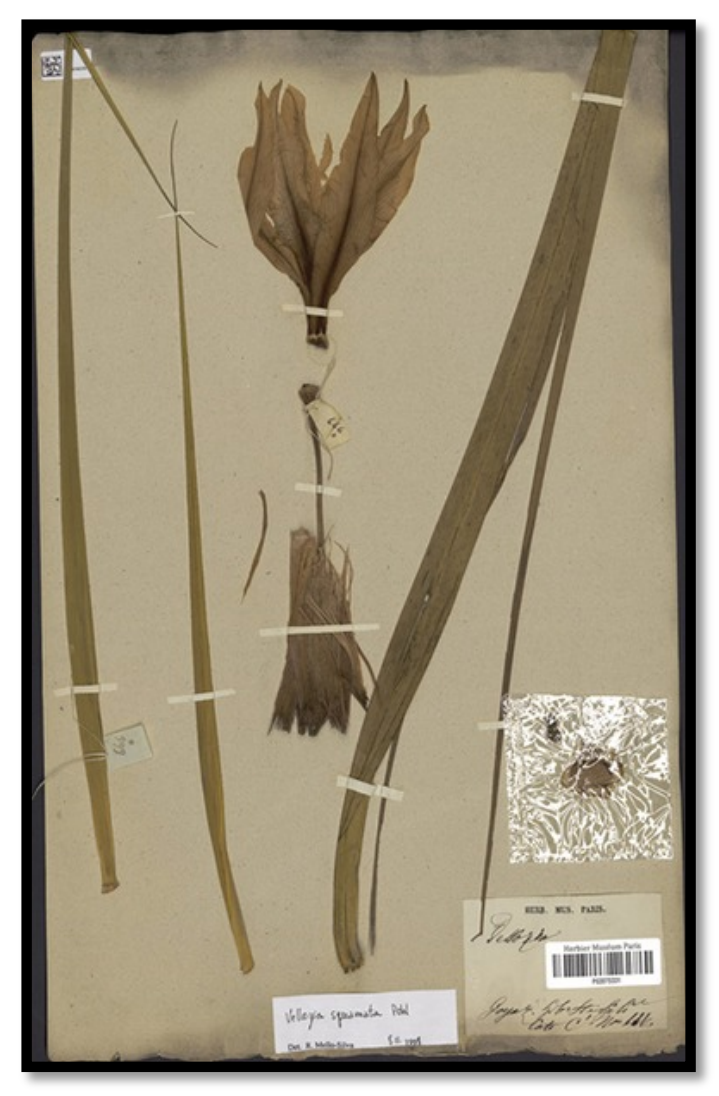

Figura 21. Imagem do herbário de A. de Saint-Hilaire: exemplar de Vellozia squamata. Data da coleta: 1816-1821. Fonte: Herbário virtual de A. de Saint-Hilaire.

Seguindo seu relato, o viajante afirmou ter encontrado uma grande variedade de plantas na Serra da Canastra, ressaltando a presenças de plantas das família Euriocaulaceae, Gentianaceae, Convolvulaceae, Escofulariaceae, Melastomaceae e Malpighiaceae nas áreas de planalto. Pudemos encontrar em grande abundância diversos representantes das Euricaulaceae, estando relacionadas com um solo arenoso e seco, assim como apresentado pelo naturalista em seu relato (Figura 22, 23 e 24). 


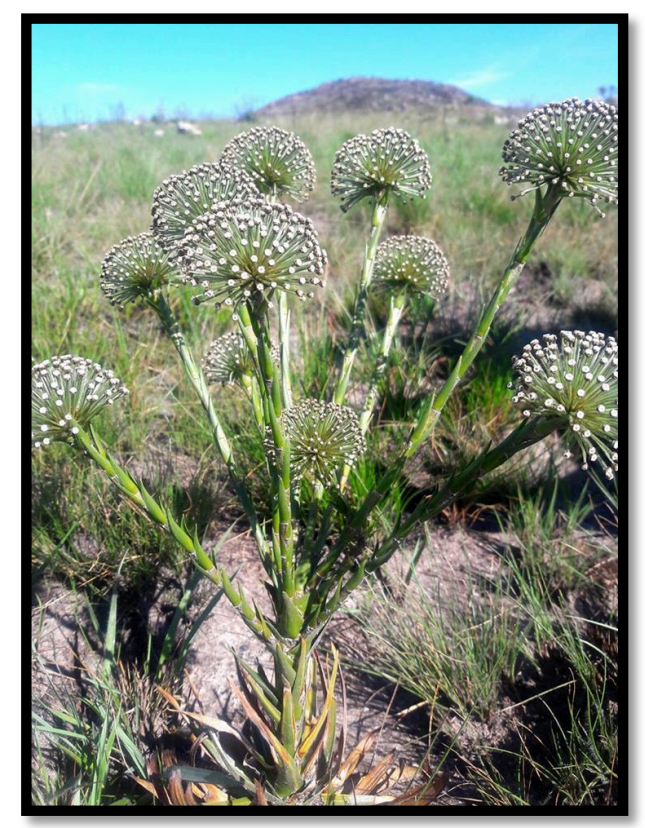

Figura 22. Foto de espécie da família Euriocaulaceae encontrada no Chapadão da Canastra. Fonte: autora.
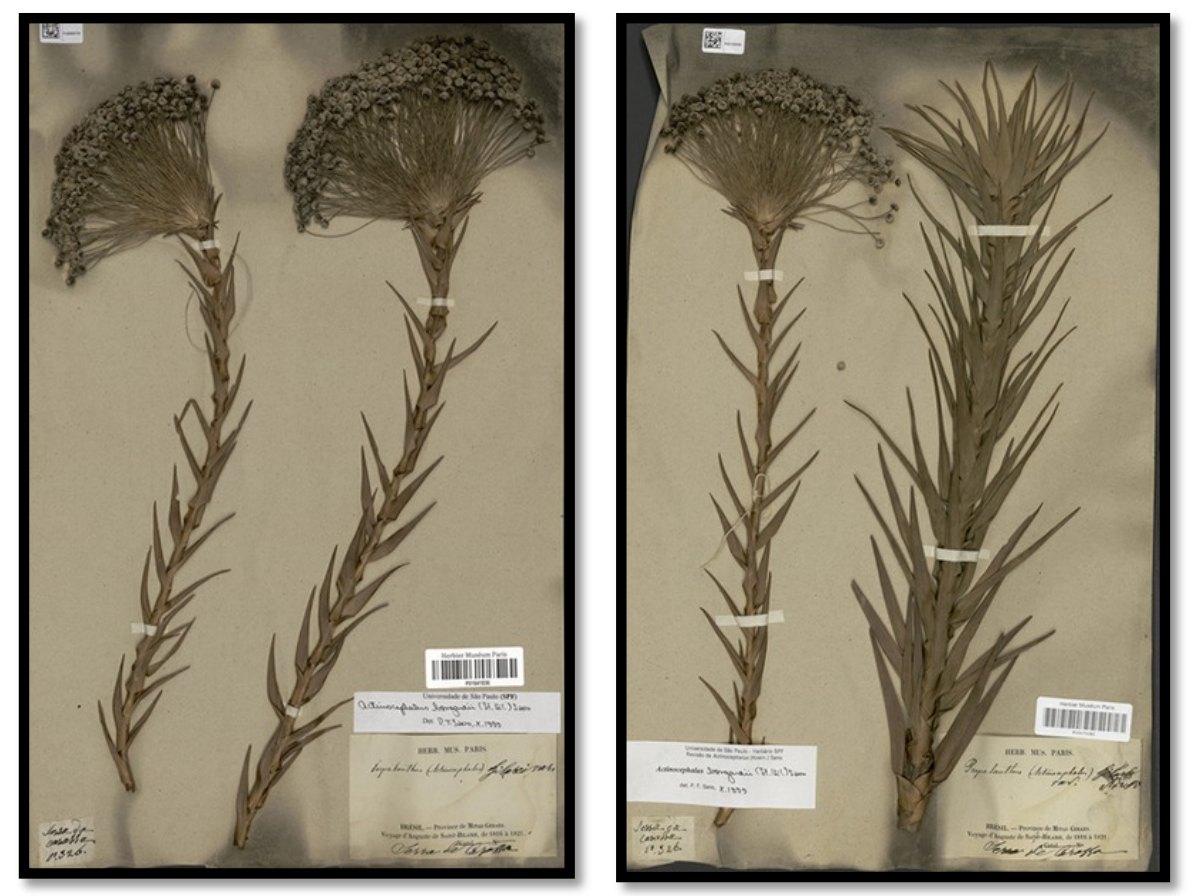

Figura 23. Imagens de exemplares de Actinocephalus bongardii coletadas e descritas por SaintHilaire, pertencentes à família Eriocaulaceae. Data: 1816-1821. Local: Serra da Canastra. Fonte: Herbário virtual de A. de Saint-Hilaire. 


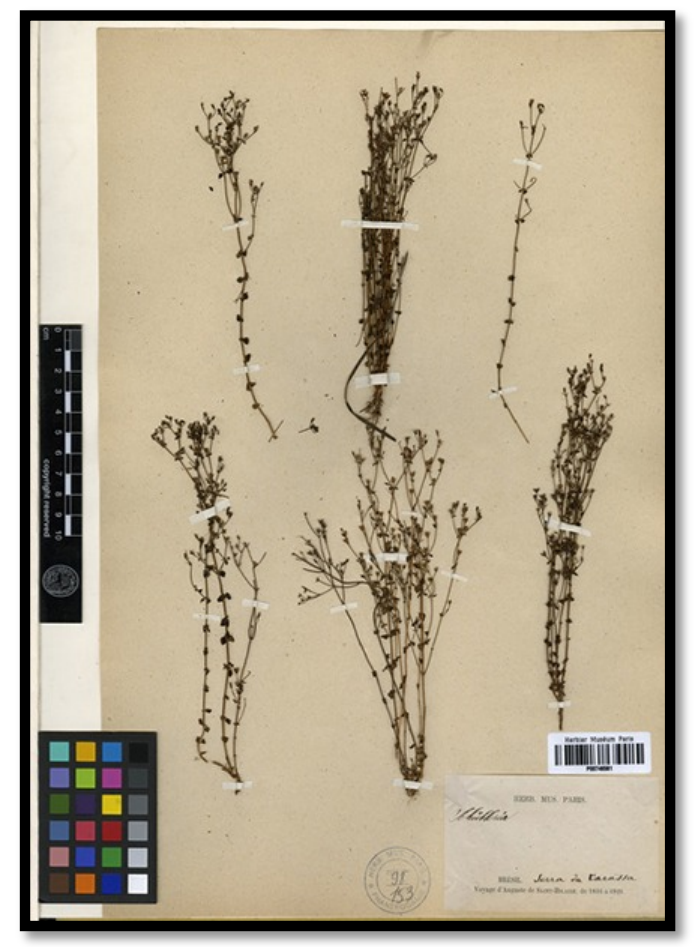

Figura 24. Imagens de Curtia sp. coletadas e descritas por Saint-Hilaire, pertencentes à família Gentianaceae. Data: 1816-1821. Local: Serra da Canastra. Fonte: Herbário virtual de A. de Saint-Hilaire.

Além disso, pudemos encontrar a planta conhecida como lobeira (Solanum lycocarpum). É uma planta espinhenta de cerca dois metros de altura que se apresenta como arbusto de porte rasteiro. Pertence à família Solanaceae e seus frutos são muito apreciados pelo lobo-guará (Figura 25 e 26). 


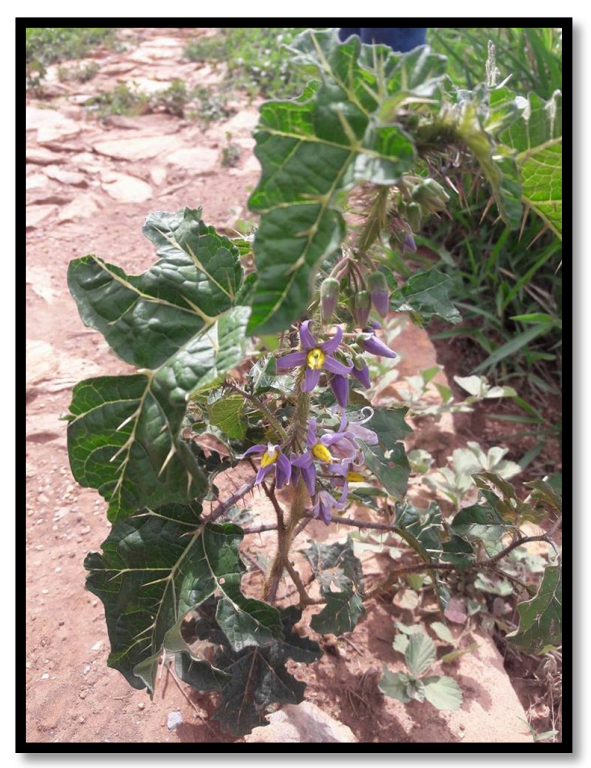

Figura 25. Lobeira encontrada no Chapadão da Serra da Canastra. Fonte: autora.

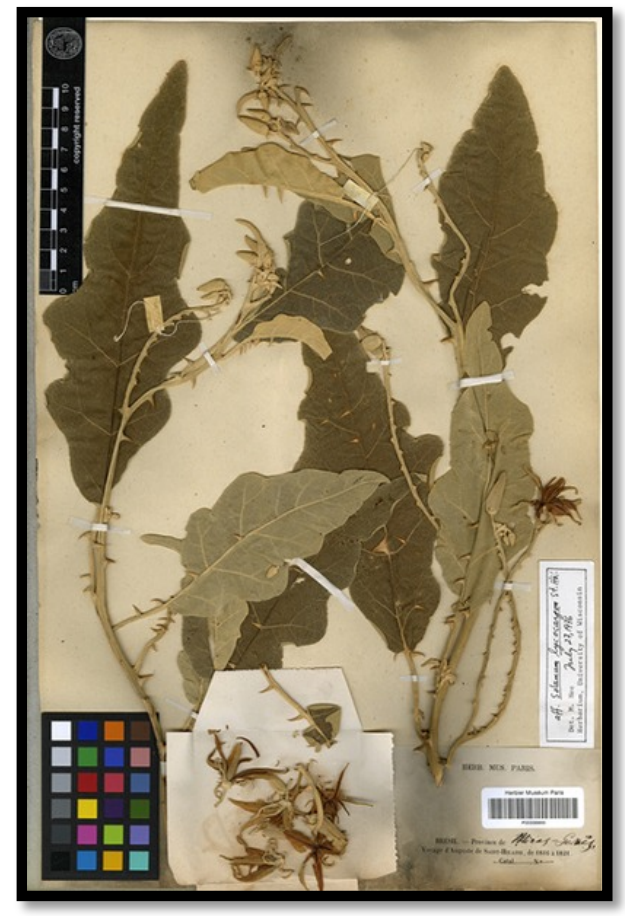

Figura 26. Imagem de Solanum lycocarpum coletadaa por Saint-Hilaire, pertencentes à família Solanaceae. Data: 1816-1821. Local: Prov. Minas Gerais. Fonte: Herbário virtual de A. de Saint-Hilaire.

A Fazenda do Geraldo que contou como local de hospedagem de SaintHilaire não foi revisitada, pois não foi possível encontrar a atual localização da antiga 
fazenda. Sabe-se que a fazenda localizava-se próxima à Cachoeira dos Rolinhos. 


\section{CAPÍTULO 6. A SEQUÊNCIA DIDÁTICA}

"When we see land as a community to which we belong, we may begin to use it with love and respect."

Aldo Leopold (1949) 
A sequência didática foi elaborada almejando-se que houvesse uma articulação de saberes acadêmicos, caracterizando-a como interdisciplinar.

O objetivo geral da sequência didática é aliar o estudo do meio a uma experiência estética, realizada por meio de uma investigação do ambiente de forma contextualizada e dinâmica. O tema da sequência didática é o resgate da trilha realizada por Saint-Hilaire na Serra da Canastra, sendo proposto que, enquanto os alunos revisitam os pontos visitados pelo naturalista, explorem e estudem o ambiente por meio de aulas práticas.

$\mathrm{Na}$ sequência didática serão abordados conteúdos de diversas áreas do conhecimento, como Botânica, Ecologia, Educação Ambiental, História da Ciência, entre outros que podem ser agregados. Para que as atividades da sequência didática sejam desenvolvidas satisfatoriamente, o curso deve ser oferecido a um número reduzido de alunos, entorno de 10 alunos.

Como já apresentado nos capítulos anteriores, o referencial teórico da pesquisa foi a Filosofia de Charles Sanders Peirce, especificamente a Estética e sua relação com a Lógica e a Ética, tendo como material base da elaboração da sequência didática as categorias da Estética da Conservação de Aldo Leopold (1949). A sequência didática foi elaborada tendo em vista sua aplicação sob a forma de uma disciplina optativa para o curso de graduação em Ciências Biológicas, ou até mesmo um curso de extensão com esse escopo. Ainda, a sequência didática também pode ser integrada à viagem de campo como parte de uma disciplina já existente, podendo sofrer alterações de acordo com a temática da disciplina e do docente responsável.

Esta pesquisa limitou-se ao estudo teórico realizado e à proposição da sequência didática apresentada a seguir, sendo que, a aplicação desta com alunos do Ensino Superior do curso de graduação em Biologia e a análise dos dados obtidos serão realizadas em trabalhos futuros.

A sequência didática foi subdividida em 3 momentos distintos, sendo eles: introdução (pré-viagem de campo); a viagem de campo; e fechamento (pós-viagem de campo). A sequência didática completa será apresentada de acordo com esses três momentos distintos.

\section{Introdução (pré-viagem de campo)}


A parte inicial do curso será realizada por meio de duas aulas teóricas, desenvolvidas em dias distintos. Nesse primeiro momento pretende-se apresentar uma introdução contendo informações pertinentes aos temas que serão tratados na viagem de campo. As aulas, os temas, e a bibliografia sugerida estão apresentadas no Quadro 3. A bibliografia descrita para as aulas apresenta-se como uma sugestão inicial, sendo que, em trabalhos futuros, quando de fato for aplicada a sequência didática, a bibliografia pode ser alterada ou extendida.

A aula 1 visa, primeiramente, apresentar o curso como um todo e inciar as aulas tratando a respeito dos naturalistas viajantes no século XIX, abordando quais eram os principais locais de origem destes indivíduos, seus objetivos, métodos de estudo e contexto no qual estavam inseridos. Posteriormente, apresentar o naturalista viajante Auguste de Saint-Hilaire, abordando a respeito de sua vida e obra e, finalmente, apresentar sua expedição à Serra da Canastra, sendo este, o foco da sequência didática. Nessa aula será lançado o desafio aos alunos para buscarem informações sobre o ambiente da Serra da Canastra para refazermos a trilha realizada por Saint-Hilaire no local, tendo o relato do naturalista como guia.

A aula 2 tem como objetivo familiarizar os alunos com o Parque Nacional da Serra da Canastra, local de nosso estudo. Será apresentada a temática das Unidades de Conservação - desde sua criação, implantação e categorias - focando na categoria dos Parques Nacionais. Assim, trataremos a respeito das principais características do Parque Nacional da Serra da Canastra, contidas em seu Plano de Manejo (2005).

Quadro 3. Aulas teóricas iniciais.

\begin{tabular}{|c|c|c|}
\hline \multicolumn{3}{|c|}{ Introdução (pré-viagem de campo) } \\
\hline & Temas & Bibliografia sugerida \\
\hline Aula teórica 1 & $\begin{array}{l}\text { - Apresentação do curso } \\
\text { - Os naturalistas viajantes } \\
\text { no século XIX. } \\
\text { - Auguste de Saint-Hilaire } \\
(1779-1853) .\end{array}$ & $\begin{array}{l}\text { ECKARDT, I. A perspectiva } \\
\text { científica da literatura de viagem } \\
\text { do século XIX: Auguste de } \\
\text { Saint-Hilaire. In. Estação } \\
\text { Literária. Vagão-volume 4, } 2009 . \\
\text { KURY, L. Auguste de Saint- } \\
\text { Hilaire: viajante exemplar. } \\
\text { Revista Intelléctus, ano 2, n. } 01 . \\
\text { p.02. São Paulo, 2003. } \\
\text { LIMA, M. E. A. T. As } \\
\text { caminhadas de Auguste de Saint- } \\
\text { Hilaire pelo Brasil e Paraguai. }\end{array}$ \\
\hline
\end{tabular}




\begin{tabular}{|l|l|l|}
\hline & & $\begin{array}{l}\text { Autêntica. 166p. Belo Horizonte, } \\
2002 .\end{array}$ \\
\hline Aula teórica 2 & $\begin{array}{l}\text { - Unidades de Conservação } \\
\text { - O Parque Nacional da } \\
\text { Serra da Canastra. }\end{array}$ & $\begin{array}{l}\text { ICMBio. Plano de Manejo do } \\
\text { Parque Nacional da Serra da } \\
\text { Canastra. Brasilia. 2005. 250p. } \\
\text { MMA. Unidades de } \\
\text { Conservação. Disponível em: } \\
\text { http://www.mma.gov.br/areas- } \\
\text { protegidas/unidades-de- } \\
\text { conservacao }\end{array}$ \\
\hline
\end{tabular}

\section{A viagem de campo}

A viagem de campo será realizada em cinco dias, tendo a cidade de São Roque de Minas - MG como local de hospedagem. Nessa viagem, como já descrito, pretende-se que os alunos refaçam alguns dos pontos da trilha de Saint-Hilaire e investiguem o meio através de aulas práticas e discussões realizadas ao longo do caminho.

Como abordado, as categorias da Estética da Conservação de Aldo Lepold servirão como base para a elaboração e desenvolvimento das aulas de campo. Segundo Leopold (1949), as categorias manifestam-se no contato com o ambiente natural de forma crescente. Dessa forma, as aulas foram pensadas e categorizadas de forma crescente, de acordo com as categorias que se transcorrem. Porém, mostra-se válido ressaltar que devido à experiência do indivíduo com o meio ser um fenômeno complexo e dinâmico, ao longo do processo, provavelmente, a resposta dos alunos irá integrar e mesclar diversas categorias, sendo pouco provável separar totalmente uma categoria de resposta ao ambiente. Por exemplo, mesmo que incialmente priorize-se a exploração da categoria do troféu, essa irá manifestar-se em diversos outros momentos da experiência no meio de forma espontânea.

Em relação à questão da indissociabilidade total das categorias de Leopold (1949), também podemos encontrar essas características nas categorias universais apresentadas na Teoria de Peirce. Quando tratamos de uma análise semiótica, na qual discorre-se a respeito da formação sígnica, não é possível encontrar um signo que apresente apenas uma de suas faces, potencialidade (primeiridade), existência (secundidade), ou conceito (terceiridade). As faces do signo encontram-se presentes em qualquer signo de qualquer natureza. Porém, pela análise semiótica podemos identificar 
qual deles, ou quais, aparecem de maneira mais preponderante no interior do signo analisado (FONSECA, 2008).

Considerando os cinco dias da viagem de campo, foram separados de acordo com as categorias de Lepold (1949), como no esquema abaixo:

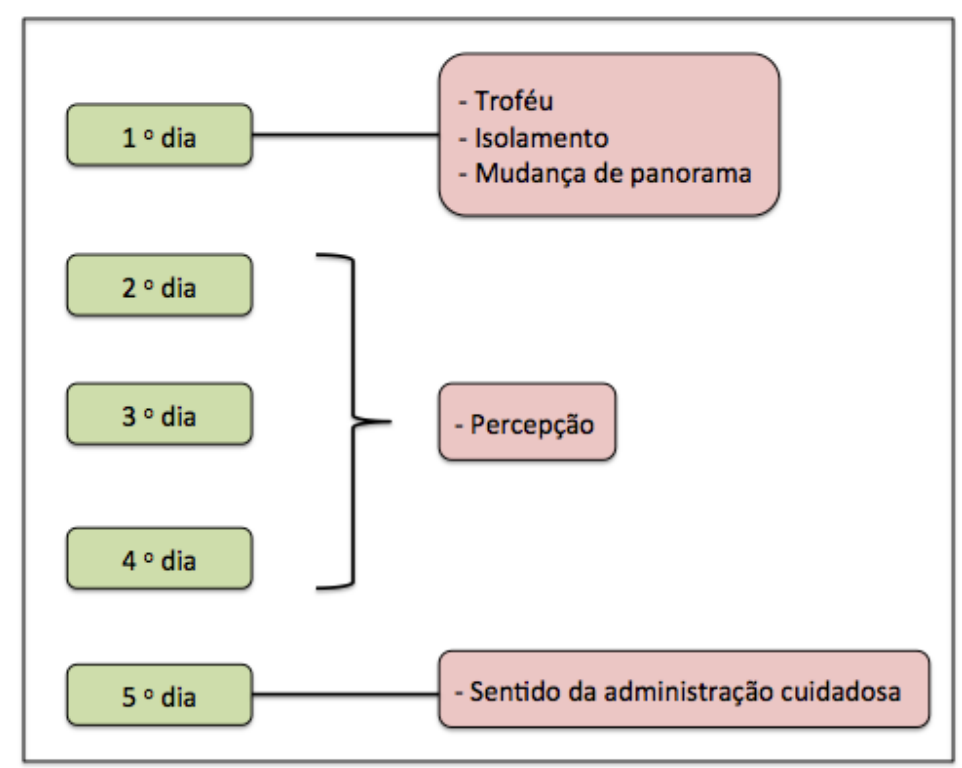

Figura 27. Esquema relacionando os dias da viagem de campo com as categorias de Aldo Lepold (1949).

\section{Primeiro dia}

Será solicitado previamente aos alunos que levem à viagem: caderno de campo pessoal, laptops e máquina fotográfica ou celular que possua câmera fotográfica. O caderno de campo será o diário de bordo para toda a viagem de campo, a principal fonte de registro dos alunos que deverá ser entregue aos professores ao final da viagem.

No primeiro dia da viagem de campo os alunos partirão de seu local de origem pela manhã e, dessa forma, as atividades se iniciarão na parte da tarde no Complexo Capão Forro, situado próximo ao centro de São Roque de Minas, propriedade que possui 4 cachoeiras e diversos poços para banho.

A primeira atividade visa propiciar um momento de integração com o ambiente, desenvolvido de forma dinâmica e mais espontânea possível. Será proposto aos alunos que se lembrem da aula na qual a temática dos naturalistas viajantes foi abordada, e assim, que retomem alguns dos detalhes apresentados a respeito da forma como estes cientistas se relacionavam com o ambiente enquanto o estudavam. Será 
solicitado aos alunos que levem seus cadernos de campo, junto de suas máquinas fotográficas e que interajam com o ambiente, assim como os naturalistas o faziam. Os alunos devem observar minusciosamente os locais que passarem e registrar os elementos que chamarem a sua atenção, seja sob a forma escrita ou por meio de fotos, desenhos ou esquemas. Em seus cadernos de campo os alunos podem apresentar aspectos biológicos do ambiente, como características da vegetação e de animais encontrados, assim como, impressões, características das habitações e das relações dos habitantes com a região, entre outros que julgarem pertinentes.

A turma de alunos será conduzida juntamente durante a trilha e na visitação das cachoeiras, porém, a atividade deve ser realizada individualmente e de forma livre, sendo que os alunos podem expressar-se, interagir e registrar em seus cadernos de campo o que sentirem vontade.

Ao voltarem da atividade da tarde, os alunos deverão elaborar uma simples apresentação, no formato Power Point, contendo os principais elementos observados e registrados em sua investigação inicial do ambiente da Serra da Canastra. Na parte da noite, a turma se reunirá para compartilhar seus resultados por meio das apresentações individuais e os diversos elementos distintos a respeito do ambiente serão apresentados e discutidos de acordo com a percepção e visão de cada aluno.

Como as primeiras três categorias de Lepold (1949) são elementos que fazem parte de uma experiência estética pessoal, apresentando-se de forma subjetiva e espontânea, levou-se em consideração que antes de iniciarem-se as aulas práticas de conteúdos formais da Biologia, um primeiro momento de envolvimento e interação com o meio deveria ser propiciado. Dessa forma, nessa primeira atividade, na qual os alunos adotam uma postura de "naturalistas contemporâneos", ao observarem o ambiente e escolherem objetos e elementos que querem registrar de alguma forma, seja por meio do desenho, da escrita, da foto ou pela coleta de um exemplar, a categoria do troféu seria contemplada. Nesse processo de observação e busca, os alunos interagiriam com o ambiente de forma individual, envolvendo-se com o ambiente e não somente pertencendo-o por meio dos troféus. Além disso, os alunos estarão livres para aproveitar momentos de recreação, juntamente de seus colegas no local, dessa forma, as categorias do isolamento e mudança de panorama podem ser contempladas. Ao final do dia, o compartilhamento da experiência estética pessoal de cada aluno chamará a atenção dos 
alunos para pontos que não talvez não tenham notado antes, mas que foram percebidos de forma distinta pelos seus colegas.

Os próximos 3 dias de atividades da viagem de campo visam contemplar a quarta categoria de Lepold (1949), a percepção, ao buscarmos explorar a questão da investigação e da busca por conhecer mais o ambiente.

\section{Segundo dia}

No segundo dia de atividades, os alunos serão orientados a formarem duplas ou pequenos grupos para realização das atividades. Inicialmente, os alunos receberão o Roteiro 1 (Apêndice A), no qual é apresentado um mapa da Serra da Canastra contendo todos os pontos passados pelo naturalista Saint-Hilaire. Será realizada uma breve revisão dos temas tratados aula teórica que apresentou os naturalistas viajantes, e especificamente, o naturalista Saint-Hilaire.

No roteiro, para cada ponto de parada, citações originais de Saint-Hilaire serão apresentadas para que possam ser lidas em conjunto com os alunos e discutidas. $\mathrm{O}$ roteiro servirá aos alunos como um guia de observação, sendo que, cada aluno deve ter seu caderno de campo para seus registros dos locais e elementos observados.

Na parte da manhã, os alunos iniciarão a visitação aos pontos, sendo que, em cada ponto os professores farão uma breve apresentação do local, abordando os elementos contidos no relato de Saint-Hilaire, e as características atuais do local. O primeiro ponto a ser visitados será a Fazenda João Dias no município de Campinópolis. Como próximo ponto, os alunos se direcionarão a Casa de Felisberto. Logo à frente, os alunos seguirão por uma trilha rumo à Casca D'anta. Ao longo do caminho os professores devem chamar a atenção dos alunos às características da vegetação daquele ambiente. Na cachoeira, a detalhada descrição do naturalista será lida conjuntamente e os alunos deverão buscar identificar cada aspecto no local atualmente, comparando essas visões. Além disso, deverão registrar outras características pertinentes observadas e que não estão contidas no relato do naturalista.

$\mathrm{Na}$ parte da tarde, os alunos realizarão uma trilha que se inicia na parte baixa da Casca D'anta e termina na parte alta. Ao longo trecho, será possível observar as diferenças da vegetação desde o ambiente mais úmido próximo à queda da cachoeira até a parte alta, onde inicia-se o Chapadão. Nesse trecho, os alunos terão contato 
empiricamente com as diferentes fitofisionomias que um ambiente pertencente ao bioma Cerrado pode apresentar. No roteiro guia, os alunos terão as formações vegetacionais presentes no Cerrado, juntamente com as diferentes fitofisionomias que podem ser encontradas no local e suas características principais. Assim, os alunos deverão analisar quais fitofisionomias são capazes de encontrar no trecho realizado e apresentar explicações para suas conclusões, registrando nos cadernos de campo. Os professores estarão disponíveis aos alunos a todo o momento para auxiliá-los e sanar possíveis dúvidas.

\section{Terceiro dia}

Após terem discutido a respeito do bioma estudado no ambiente da Serra da Canastra, na parte da manhã, será desenvolvida uma aula teórica participativa abordando o conteúdo Formas de Vida, especificamente na área da Ecologia Vegetal.

O objetivo da aula será apresentar uma forma de classificação das plantas alternativa ao sistema de classificação científico usual, utilizando-se- de meios informais de classificar - como árvores, arbustos, ervas, trepadeiras, etc - e as classificações utilizadas na ciência que enfatizam a função da planta no ecossistema, tendo o sistema de Raunkiær, como o mais utilizado. Ao apresentarmos o Sistema de classificação das formas de vida segundo Raunkiaer, enfatizaremos na adaptação da classificação realizada às condições brasileiras (IBGE, 2012).

Na parte da tarde, seguindo o mapa de Saint-Hilaire, após termos passado na parte baixa da Casca D'anta para a alta, o próximo ponto a ser visitado seria a Nascente do Rio São Francisco. Neste ponto, será desenvolvida uma aula prática referente ao conteúdo apresentado pela manhã. Cada grupo deverá analisar duas áreas distintas, tendo o Roteiro 2 (Apêndice B) como apoio, levando em consideração quais formas de vida irão encontrar em cada uma dessas áreas. Os grupos deverão escolher uma pequena área próxima a nascente do Rio e outra mais distante da presença da água para fins de estudo. Os alunos deverão escolher o tamanho de cada uma das áreas, apresentando uma medida aproximada que considerem relevante para a análise. O sistema de Raunkiær estará apresentado no roteiro, juntamente de uma chave de classificação das formas de vida segundo Raunkiaer, modificada e adaptada ao Brasil (IBGE, 2012). Dessa forma, os alunos deverão realizar uma contagem aproximada de quais e quantas formas de vida 
são encontradas em cada área.

$\mathrm{Na}$ parte da noite, cada grupo irá apresentar seus resultados por meio de uma apresentação de Power Point e relacionar os seus dados com a questão da presença ou ausência da água no local. Será realizada uma discussão a respeito da relação da água com a fisionomia da vegetação, assim como apresentado por Saint-Hilaire em seu relato.

\section{Quarto dia}

Na parte da manhã, uma aula teórica será apresentada aos alunos sobre o ambiente do Chapadão. Trechos do relato de Saint-Hilaire contendo as famílias de plantas que foram encontradas por ele no local serão apresentadas de forma detalhada. Tais famílias serão descritas por meio de imagens contendo suas principais características.

Logo após a aula teórica, uma rápida visitação à atual Capela de São Roque será realizada, apresentando o que foi descrito por Saint-Hilaire e as mudanças sofridas com o passar do tempo.

Na parte da tarde, o próximo ponto a ser visitado será região do Chapadão, onde realizarão uma atividade prática referente à identificação de plantas que possívelmente fazem parte das famílias citadas por Saint-Hilaire. Por meio do auxílio dos professores e da aula teórica da manhã, os alunos buscarão na identificar no campo plantas que sejam representantes das famílias descritas por Saint-Hilaire.

Os professores irão auxiliar os alunos a todo o momento na identificação das plantas, ensinando como realizar a coleta de plantas para fins científicos, além de apresentar quais são os materiais necessários para essa prática. Assim, os alunos coletarão as plantas identificadas para posterior análise. Durante a atividade no Chapadão, os professores deverão discutir com os alunos a possível relação da vegetação da área com os animais presentes, relacionando as plantas com seus possíveis polinizadores e dispersores. Após a aula de campo, na parte da noite, os alunos farão exsicatas das plantas coletadas, juntamente com os professores.

\section{Quinto dia}

No último dia, buscamos elaborar uma atividade que contemplasse a última 
categoria de Leopold (1949), o sentido da administração cuidadosa. Após os alunos terem se envolvido com o ambiente, buscando conhecê-lo melhor por meio das aulas de campo, será feita uma abordagem no campo da ética e dos valores.

$\mathrm{Na}$ parte da manhã, com o grupo reunido discutiremos quais foram as principais mudanças que puderam encontrar no ambiente em relação ao que leram nos relatos de Saint-Hilaire. Os alunos deverão avaliar se as mudanças elencadas foram possitivas ou negativas. Será apresentada uma lista contendos diversos animais e plantas da Serra da Canastra que encontram-se na lista de risco de extinção, de acordo com o Plano de Manejo do Parque (2005).

Como atividade final, cada grupo de alunos deverá elaborar um Projeto de Educação Ambiental voltado ao público que visita o Parque ou aos próprios moradores da região, com foco em conteúdos integradores da flora e fauna da região. $\mathrm{Na}$ elaboração do projeto os alunos deverão analisar quais são as principais demandas a serem tratadas com o público alvo em questão, levando-se em consideração a questão da conservação da biodiversidade.

\section{Fechamento (pós- viagem de campo)}

$\mathrm{Na}$ última aula do curso, em sala de aula, os alunos divididos em trios deverão apresentar seminários a respeito dos Projetos de Educação Ambiental elaborados no último dia da viagem. Prevê-se uma discussão final sobre os elementos contidos em cada projeto e sua viabilidade prática. Os alunos serão avaliados por meio da participação nas atividades durante todo o curso, dos registros da viagem nos cadernos de campo e dos seminários finais.

$\mathrm{Na}$ figura 28 estão sistematizadas as diversas atividades da sequência didática atreladas às categorias propostas por Leopold (1949). 
Introdução: pré-viagem de campo

- Aula teória 1: Os naturalistas viajantes no século XIX./ Auguste de Saint-Hilaire (1779-1853). - Aula teórica 2: Unidades de Conservação./ O Parque Nacional da Serra da Canastra.

\section{Viagem de campo: nas trilhas de Saint-Hilaire}

$1{ }^{\circ} \mathrm{dia}$ : Complexo Capão Forro

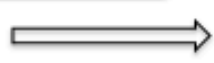

Troféu

Isolamento

- Mudança de panorama

$2^{\circ}$ dia: -Fazenda João Dias

- Casa do Felisberto

- Cachoeira Casca D'anta

- Trilha Casca D'anta - fisionomias do Cerrado

3 'dia: - Aula teórica 3: "Formas de Vida"

- Nascente do Rio São Francisco - prática "Formas de Vida"

- Percepção

- Apresentação dos resultados

$4^{\circ}$ dia: - Aula teórica 4: Chapadão e o relato de Saint-Hilaire

- Capela de São Roque

- Cerradão - prática identificação de famílias

$5^{\circ}$ dia: - Elaboração de Projetos de EA

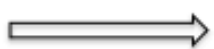

- Sentido da administração cuidadosa

Fechamento: pós-viagem de campo

- Seminários: Projetos de EA

Figura 28. Esquema geral da Sequência Didática completa. 


\section{CONSIDERAÇÕES FINAIS}

Esta pesquisa investigou o que é a Estética para Charles Sanders Peirce e qual o seu papel dentro da arquitetura filosófica elaborada pelo cientista. Além disso, este trabalho buscou discutir a importância da Estética no Ensino de Biologia.

$\mathrm{Na}$ pesquisa realizada pudemos concluir que a visão de Peirce sobre a Estética não se limita somente à ciência do belo, como inicialmente imaginávamos. A Estética de Peirce é mais abrangente e reside na essência de qualquer objeto apreendido em nossa experiência que desperta nossa atenção, seja ele considerado belo ou não pelas convenções. Seria algo que consideramos "admirável", que temos vontade de admirar sem qualquer motivo. No admirável encontra-se a potencialidade do conhecer, de entender um pouco mais, ou seja, no admirável reside o crescimento da razoabilidade concreta, a potencialidade do desenvolvimento da ideia. $\mathrm{O}$ conhecimento se dá porque antes nossos sentidos são direcionados a algo que desperta nossa atenção. O ideal último do ser humano é conhecer, alcançar uma razoabilidade, sendo algo que motiva nossa existência.

Ao buscarmos uma relação de como a Filosofia Estética pode relacionar-se com o Ensino de forma aplicável, deparamo-nos com o cientista Aldo Leopold cujas ideias dialogam com as de Peirce. Sua obra intitulada $A$ Sand County Almanac and Sketches Here and There (1949) apresenta níveis de resposta estética dada pelo ser humano no ambiente natural. As categorias troféu, isolamento, e ar livre e mudança de panorama estão relacionadas a uma resposta puramente estética na busca de um envolvimento com o ambiente, resultando em emoções positivas e maravilhamento. A categoria da percepção integra a observação, articulando experiência estética ao conhecimento. A categoria sentido da administração cuidadosa trata da questão da conservação e do cuidado à terra. A última categoria consolida o processo em que o indivíduo se encanta, observa e compreende o meio, sendo mais provável que possua o desejo de conservá-lo. Assim, o diálogo das ideias de Peirce com as categorias de Leopold delimita uma relação clara da transposição dos conceitos filosóficos à categorias que podem ser utilizadas em um contexto educacional ou recreativo. Com isso, envolver no Ensino o admirável/belo, os valores e a formalização do pensamento sob a forma de linguagem (estética, ética e lógica) pode ser uma estratégia didática 
relevante aos estudos do meio. Portanto, apresentamos as categorias de Aldo Leopold (1949) como uma ferramenta relevante ao planejamento e aplicação de atividades voltadas ao estudo do meio, tendo a Estética Peirceana como fundamento.

Em relação à discussão voltada à utilização dos elementos estéticos em aulas de campo como uma estratégia didática pertinente à abordagem da biodiversidade, postulada como uma pergunta inicial de pesquisa, acreditamos que neste trabalho os resultados não foram suficientes para apresentar uma explanação consistente a respeito da questão. A pergunta de pesquisa poderá ser respondida mediante a aplicação da sequência didática e a análise dos dados que serão realizadas futuramente.

Dessa forma, a pesquisa limitou-se a um estudo teórico e à proposição de uma sequência didática, sendo que, a aplicação desta com alunos do Ensino Superior do curso de graduação em Biologia e a análise dos dados obtidos serão realizadas em trabalhos futuros. 


\section{REFERÊNCIAS BIBLIOGRÁFICAS}

ALlCHIN, D. Listening To Whales. The American Biology Teacher, v. 3, n. 77, p.220-222, mar. 2015. Disponível em: $<$ http://www.tc.umn.edu/ allch001/papers/Allchin-SB-Listening-to-Whales.pdf $>$. Acesso em: 05 jun. 2015.

BARILli, R. A. Course on Aesthetics. Minneapolis: University Of Minnesota Press, 1989.

BATES, H. W. Um naturalista no rio Amazonas. [1863]. Belo Horizonte: Editora Atibaia, 1979.

BERNSTEIN, R. J. A Sedução do Ideal. Em Face 3, São Paulo, n. 2, p. 195-206. 1990.

BRASIL. PCN+ ensino médio: orientações educacionais complementares aos Parâmetros Curriculares Nacionais. Ciências da natureza, matemática e suas tecnologias. Brasília: Semtec, 2002.

MMA. A unidade de conservação e o território: reconhecendo o contexto socioambiental e geopolítico. Série educação ambiental e comunicação em unidades de conservação. Brasília: 2015.

CALADO, A. J. F. Paulo Freire: sua visão de mundo, de home e de sociedade. Caruaru: FAFICA, 2001.

CAVASSAM, O.; PINHEIRO, P. G. S.; SENICIATO, T. O Ensino das Ciências, A biodiversidade e o Cerrado. BIOTA-FAPESP, Divulgação Científica e Ensino de Ciências: Estudos e Experiências. v. 7, p. 190-219. São Paulo - SP: BIOTAFAPESP, Divulgação Científica de Ciências: Estudos e Experiências, v.7. 2006.

COLlege, B. M. Editorial Note in Collected Papers of Charles Sanders Peirce. In: 
Hathorne, C., Weiss, P. (Org.). Harvard University Press, InteLex Corporation. v. V. 1934.

CURLEY, T. The Relation of the Normative Sciences to Peirce's Theory Inquiry. Em Transctions of the Charles S. Peirce Society. v. 5, n. 2, p. 91-106. 1969.

DEWEY, J. Art as Experience. New York: Putnam, 1934.

DAMASIO, A. R. O erro de Descartes. São Paulo: Companhia da Letras, 2001.

ECKARDT, I. A perspectiva científica da literatura de viagem do século XIX:

Auguste de Saint-Hilaire. In. Estação Literária. Vagão-volume 4, 2009. Disponível em: < http://www.uel.br/pos/letras/EL>

FLANNERY, M. C. The conservation aesthetic and the microscopic aesthetic. Bioscience, v. 49, p. 801-808. 1999.

FONSECA, G.; CALDEIRA, A. M. A. Ensino e Aprendizagem de Ecologia em Ecossistemas Naturais Característicos da Restinga de Ilha Comprida SP. In: Elaine Sandra Nicolini Nabuco de Araújo; João José Caluzi; Ana Maria de Andrade Caldeira. (Org.). Práticas integradas para o ensino de biologia. São Paulo: 2008.

HERBÁRIO VIRTUAL A. DE SAINT-HILAIRE. História do naturalista. Disponível em: < http://hvsh.cria.org.br/history $>$ Acesso em: 1 de dez. 2016.

IBGE. Instituto Brasileiro de Geografia e Estatística. Manual Técnico da Vegetação Brasileira. 2aed. 271p. 2012.

ICMBIO. Parna da Serra da Canastra. Disponível em: $<$ http://www.icmbio.gov.br/portal/unidadesdeconservacao/biomas-brasileiros>. Acesso em: 24 de outubro. 2016. 
ICMBIO. Plano de Manejo do Parque Nacional da Serra da Canastra. Brasília. $250 \mathrm{p}, 2005$.

KRASILCHIK, M. Reformas e realidade: o caso do ensino das ciências. São Paulo, Perspec, vol.14, n.1, p.85-93, 2000. Disponível em: $<$ http://dx.doi.org/10.1590/S0102-88392000000100010>

KURY, L. Auguste de Saint-Hilaire: viajante exemplar. Revista Intelléctus, São Paulo, ano 2, n. 01, p.02. 2003.

LEOPOLD, A. A Sand County Almanac and Sketches Here and There. New York: Oxford University Press, 1949.

LIMA, M. E. A. T. As caminhadas de Auguste de Saint-Hilaire pelo Brasil e Paraguai. Belo Horizonte: Autêntica, 2002.

MATURANA, H.; ZÖLLER, G. V. Amar e Brincar: fundamentos esquecidos do humano. Trad. Humberto Mariotti e Lia Diskin. São Paulo: Palas Athena, 2004.

MERLEAU-PONTY, M. O olho e o espírito. São Paulo: Os Pensadores, 1984; orig. L'oeil et l'esprit, Paris, Gallimard, 1964.

MMA. Unidades de Conservação. Disponível em: <http://www.mma.gov.br/areasprotegidas/unidades-de-conservacao > Acesso em: 24 de outubro. 2016.

MORIN, E. A cabeça bem feita: repensar a reforma, reformar o pensamento. Rio de Janeiro: Bertrand Brasil, 2000.

NASCIMENTO, L. A.; AZEVEDO, G.; GHIGGI, G. O conceito de amorosidade em freire e a recuperação do sentido de educar. 2013. Disponível em: $<$ http://coloquio.paulofreire.org.br/participacao/index.php/coloquio/viiicoloquio/p 
aper/download/46/308> Acesso em: 25 de jul. 2015.

PARRET, H. Fragmentos Peirceanos sobre a Experiência Estética. Em Face, São Paulo, vol. 3, p. 217-228. 1990.

PEIRCE, C. S. Escritos Coligidos. Trad. Armando Mora D'Oliveira e Sérgio Pomerangblum. São Paulo: Abril Cultura, 1983.

. Semiótica e Filosofia. Trad. Mota e Hegenberg. São Paulo: Cultrix, 1972.

Collected Papers of Charles Sanders Peirce. In: HATSHORNE, C., WEISS, P. (Org.). Harvard University Press, InteLex Corporation, 1931-35 and 1958. v. I-IV. CD-ROM. 1994.

POTTER, V. Peirce's analysis of the Normative Sciences. Em Transactions of the Charles S. Peirce Society, v.2, n.1, p. 5-32. 1967.

SAINT-HILAIRE, A. Viagem às nascentes do Rio São Francisco e pela província de Goiás. Companhia Editora Nacional, 1937.

SANTAELLA, L. O que é semiótica. São Paulo: Brasiliense, 1993.

. Estética: de Platão a Peirce. 2. ed. São Paulo: Experimento, 1994.

. Semiótica aplicada. São Paulo: Pioneira Thomson Learning, 2002.

SILVA, A. P.; VIEIRA, G. G.; FARINASSO, M.; CARLOS, R, J. Determinação da extensão do rio São Francisco. In: Simpósio Brasileiro de Sensoriamento Remoto (SBSR), 11., 2003, Belo Horizonte. São José dos Campos: INPE, 2003.

SILVEIRA, L.F.B. Curso Introdutório de Semiótica. (Apostila digitada). 2002. 
SMITH, C. M. The Aesthetics of Charles Sanders Peirce. Em Jornouls of Aesthetics and Art Criticism, v. 31, p. 21-29. 1972.

SENICIATO, T; CAVASSAN, O. Aulas de campo em ambientes naturais e aprendizagem em ciências - um estudo com alunos do ensino fundamental. Em Ciência \& Educação, v. 10, n. 1, p. 133-147. 2004.

SENICIATO, T. CAVASSAN, O. SILVA, P. G. P. Construindo valores estéticos nas aulas de ciências desenvolvidas em ambientes naturais. Em Ensaio, v. 8, n. 2. 2006.

THE ALDO LEOPOLD FOUNDATION. Aldo Leopold. Disponível em: $<$ https://www.aldoleopold.org/about/aldo-leopold/>. Acesso em: 1 de dez. 2016.

TONIOLO, J. M. S. A. Diálogo e amorosidade em Paulo Freire: princípios às atitudes na formação de professores. Santa Maria: UFSM, 2010.

WANNER, M. C. A. Paisagens sígnicas: uma reflexão sobre as artes visuais contemporâneas. Salvador: EDUFBA, 2010.

WATTS, M. Science and poetry: Passion v. prescription in school science? Em J. Sci. Educ., v. 2, n. 23, p.197-208. 2001. 


\section{APÊNDICE A - ROTEIRO 1}

\section{NAS TRILHAS DE SAINT-HILAIRE: Roteiro 1 \\ 1) Iniciando a Trilha}

Este roteiro deve ser utilizado como um guia de observação na visitação dos pontos passados pelo naturalista Saint-Hilaire em sua expedição à Serra da Canastra. As observações e discussões podem ser realizadas em grupo, porém, cada aluno deve possuir seu caderno de campo como fonte de registro. Lembre-se de atentar a observação para os elementos do meio, como a vegetação, os animais, as alterações antrópicas no meio, característica dos habitantes na região, etc. Além disso, note as mudanças no que foi descrito nos relatos do naturalista e o que se pode observar nos dias atuais.

\section{Mapa geral da Trilha}

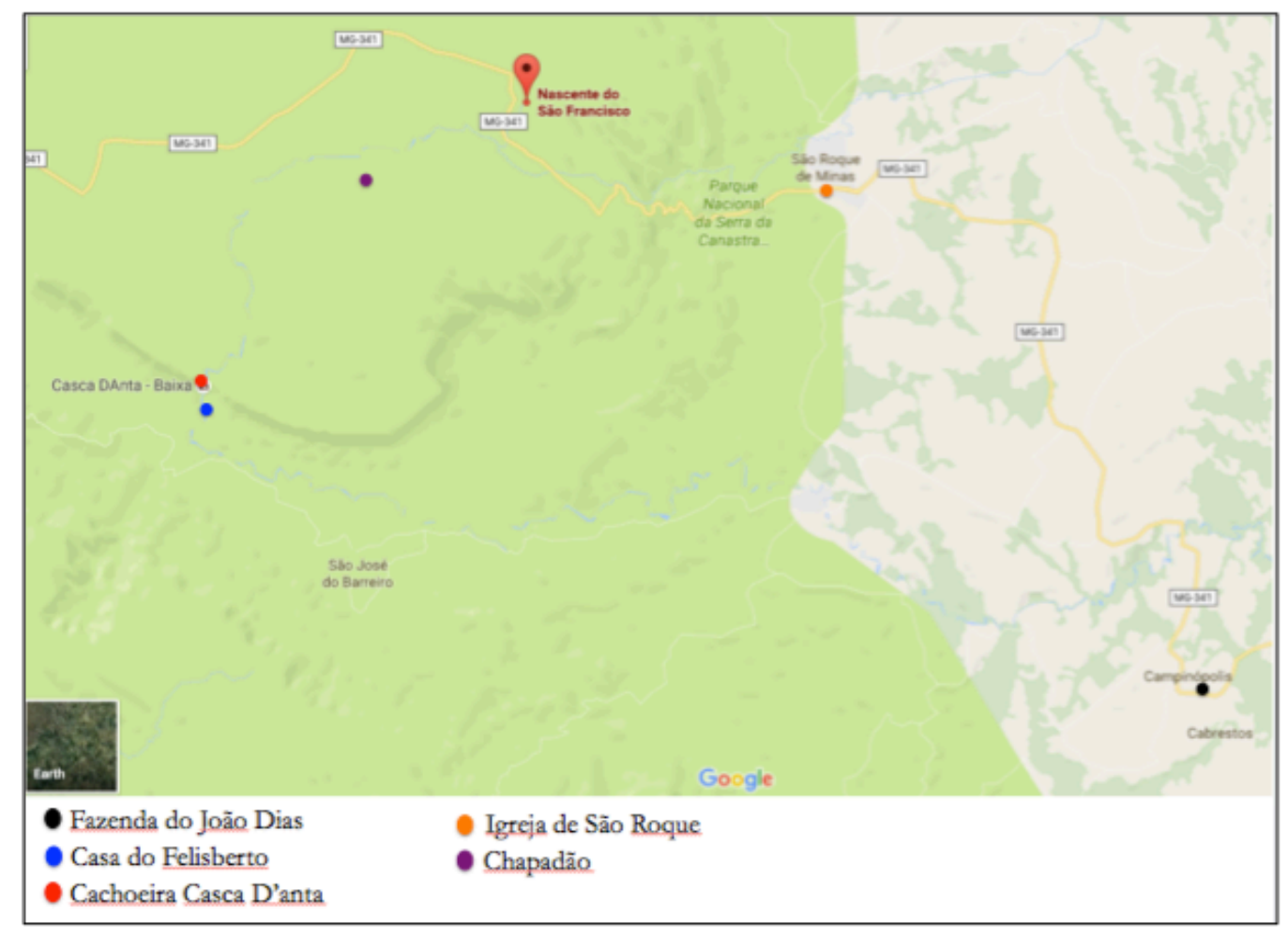

\section{1) Fazenda João Dias}

Já tínhamos feito mais de três léguas sem que encontrássemos uma única habitação, embora não tivessem dito que haviam várias pelo caminho. Também não vimos viajantes e nem sinal de gado. Era uma bela solidão, mas uma solidão profunda. [...] Tínhamos já atravessado vários riachos de uma limpidez inigualável, entre eles o Ribeirão da Prata e o Ribeirão da Capivara, e 
durante o resto da viagem passamos ainda por outros, todos afluentes do S. Francisco (SAINTHILAIRE, 1937, p.102).

\section{2) Casa do Felisberto}

Felisberto, se ainda estiver vivo, já não deve mais se lembrar do estrangeiro que um dial the foi pedir abrigo. Quanto a mim, ainda o vejo sentado num banco de madeira, num cômodo escuro e sem móveis, e me parece ouvi-lo contar com calma as afrontas e vexames de que tinha sido vítima. Os exemplos de honestidade e de virtude não são tão comuns para que possamos esquecê-los facilmente (SAINT-HILAIRE, 1937, p.104).

\section{3) Casca D’anta}

Acima dela vê-se, como já disse, uma larga fenda na rocha. No ponto onde caem as águas, as pedras formam uma concavidade pouco pronunciada. Da casa de Felisberto, a cachoeira me pareceu ter apenas um terço da altura das rochas, mas após tê-la observado de diversos ângulos creio poder afirmar que sua extensão é de dois terços dessa altura. Não a medi, (...), ela deve ter uns 203 metros, aproximadamente. Ela não se precipita das rochas com violência, exibindo, pelo contrário, um belo lençol de água branca e espumosa que se expande lentamente e parece formado por grandes flocos de neve. As águas caem numa bacia semicircular, rodeada de pedras amontoadas desordenadamente, de onde descem por uma encosta escarpada para formar o famoso Rio S. Francisco. (...) Dos dois lados da cachoeira as rochas são permanentemente úmidas e, embora talhadas a pique, mostram-se cobertas por uma relva muito verde e fina, que raramente deixa entrever a cor acizentada da pedra. Abaixo das rochas o terreno vai em declive até o rio, e no trecho mais próximo da cachoeira sua vegetação é composta só de arbustos. Mais adiante, porém, ele já se apresenta coberto de densas matas, onde se vêem numerosas palmeiras de troncos delgados e pequena altura. O verdor das plantas é de um viço extraordinário, que a proximidade das águas se encarrega de conservar. (...) Para se ter uma ideia de como é fascinante a paisagem ali, o leitor deve imaginar estar vendo em conjunto tudo o que a Natureza tem de mais encantador: um céu de um azul puríssimo, montanhas coroadas de rochas, uma cachoeira majetosa, águas de uma limpidez sem par, o verde cintilante das folhagens e, finalmente, as matas virgens, que exibem todos os tipos de vegetação tropical (SAINT-HILAIRE, 1937, p.105).

\section{1) Trilha da parte baixa da Casca D'anta para a parte alta}

Ao longo do trecho da trilha, os alunos deverão analisar a vegetação presente no meio, e assim, apresentar quais fitofisionomias do Cerrado são capazes de encontrar, de acordo com as informações fornecidas (retirado do Plano de Manejo do PNSC, 2005). As conclusões devem ser registradas nos cadernos de campo juntamente das explicações para as conclusões.

A área do Parque e seu entorno situam-se no domínio fitogeográfico do cerrado. A maior parte do Parque Nacional da Serra da Canastra é coberta por formações campestres, que englobam três diferentes tipos fitofisionômicos: campo-sujo, campo rupestre e campo limpo e por formações savânicas representadas pela fitofísionomia cerrado, sentido restrito, o qual inclui as subdivisões fisionômicas cerrado denso, 
cerrado ralo e cerrado rupestre. O PNSC apresenta praticamente todas as fitofisionomias que englobam formações florestais, savânicas e campestres, conforme apresentado no quadro disposto adiante.

\begin{tabular}{|c|c|c|c|}
\hline $\begin{array}{c}\text { Formaçōes } \\
\text { Vegetacionais }\end{array}$ & $\begin{array}{c}\text { Tipos } \\
\text { Fitofisionômicos }\end{array}$ & $\begin{array}{l}\text { Subtipos } \\
\text { Fisionômicos }\end{array}$ & $\begin{array}{c}\text { Classificação das } \\
\text { Formaçōes Segundo o } \\
\text { IBGE }\end{array}$ \\
\hline Savânicas & $\begin{array}{l}\text { Cerrado sentido } \\
\text { restrito (ce) }\end{array}$ & $\begin{array}{l}\text { Cerrado Denso (ced) } \\
\text { Cerrado Ralo (cer) } \\
\text { Cerrado Rupestre (cerp) }\end{array}$ & $\begin{array}{l}\text { savana arborizada densa }{ }^{*} \\
\text { savana arborizada rala * } \\
\text { refúgio ecológico arbustivo } \\
\text { montano }\end{array}$ \\
\hline \multirow[t]{3}{*}{ Campestres } & Campo Limpo (cl) & $\begin{array}{l}\text { Seco (cls) } \\
\text { - com Murundus (clsm) } \\
\text { - sem Murundus (clss) } \\
\text { Úmido (clu) }\end{array}$ & $\begin{array}{l}\text { savana gramineo-lenhosa } \\
\text { - (IBGE não classifica) } \\
\text { - (IBGE não classifica) } \\
\text { vegetaçāo pioneira de } \\
\text { influência fluvial herbácea }\end{array}$ \\
\hline & Campo-Sujo (cs) & $\begin{array}{l}\text { Seco (css) } \\
\text { - com Murundus (cssm) } \\
\text { - sem Murundus (csss) } \\
\text { Úmido (csu) }\end{array}$ & $\begin{array}{l}\text { savana parque } \\
\text { - (IBGE não classifica) } \\
\text { - (IBGE não classifica) } \\
\text { vegetação pioneira de } \\
\text { influência fluvial arbustiva }\end{array}$ \\
\hline & $\begin{array}{l}\text { Campo Rupestre } \\
\text { (crp) }\end{array}$ & & $\begin{array}{l}\text { refúgio ecológico arbustivo } \\
\text { montano }\end{array}$ \\
\hline \multirow[t]{3}{*}{ Florestais } & Mata Ciliar (fc) & & $\begin{array}{l}\text { genericamente como floresta- } \\
\text { de-galeria }\end{array}$ \\
\hline & Mata de Galeria & $\begin{array}{l}\text { Inundável (fal) } \\
\text { (= Floresta Alagada = } \\
\text { Mata Paludosa) } \\
\text { não Inundável (fcs) }\end{array}$ & $\begin{array}{l}\text { floresta estacional } \\
\text { semidecidual aluvial } \\
\text { inundável * } \\
\text { floresta estacional semi- } \\
\text { decidual aluvial nāo inundável * }\end{array}$ \\
\hline & $\begin{array}{l}\text { Floresta Tropical } \\
\text { Subperenifólia } \\
\text { (= Mata de Encosta) } \\
\text { (me) }\end{array}$ & & $\begin{array}{l}\text { floresta estacional } \\
\text { semidecidual montana }\end{array}$ \\
\hline
\end{tabular}

\begin{tabular}{|l|l|l|l|}
\hline & $\begin{array}{l}\text { Floresta Mesófila } \\
\text { Estacional (fm) } \\
\text { (= Mata Seca) }\end{array}$ & $\begin{array}{l}\text { Subperenifólia (fes) * } \\
\text { Semidecidual (fsd) }\end{array}$ & $\begin{array}{l}\text { floresta estacional } \\
\text { semidecidual submontana } \\
\text { (IBGE näo diferencia os } \\
\text { subtipos) }\end{array}$ \\
\cline { 2 - 4 } & $\begin{array}{l}\text { Floresta Esclerófila } \\
\text { (= Cerradāo) (cd) }\end{array}$ & savana florestada \\
\hline
\end{tabular}

\section{Formações Savânicas}

\section{Cerrado Sentido Restrito}

O cerrado sentido restrito apresenta árvores baixas, tortuosas, com ramificações irregulares e retorcidas. Os arbustos e subarbustos encontram-se espalhados, com muitas espécies apresentando órgãos subterrâneos perenes (xilopódios) que permitem a rebrota após a queima ou corte. O cerrado sentido restrito ocorre em latossolos profundos, de textura argilosa, em locais de relevo plano e suave ondulado.

O cerrado denso é um subtipo de vegetação predominantemente arbóreo representando a forma mais densa e alta de cerrado sentido restrito, com os estratos arbustivo e herbáceo mais ralos. Já o cerrado ralo é um subtipo de vegetação arbóreoarbustiva representando a forma mais baixa e menos densa do cerrado sentido restrito com o estrato arbustivo-herbáceo mais destacado que no cerrado denso. 


\section{Cerrado Rupestre}

O cerrado rupestre é considerado uma subdivisão fisonômica distinta do cerrado sentido restrito e caracteriza-se por apresentar a vegetação arbóreo-arbustiva em ambientes rupestres com solos litólicos ou rochosos, havendo, muitas vezes, uma maior concentração de indivíduos arbóreos nas fendas entre as rochas. A cobertura vegetal varia de $5-20 \%$ e altura média de $2-4$ metros. A estrutura é bastante semelhante ao cerrado ralo, diferenciando-se deste principalmente pelo substrato, já que apresenta pouco solo entre os afloramentos rochosos.

\section{Formações Campestres}

\section{Campo Limpo}

O campo limpo seco é uma fitofisionomia predominantemente herbácea, com poucos arbustos e ausência total de árvores e ocorre em latossolos ácidos e mal drenados, em locais onde o relevo é suave e ondulado com declividade ligeiramente acentuada e com presença de lençol freático profundo.

O campo limpo úmido é uma subdivisão fisionômica do campo limpo e ocorre em solos areno-argilosos das vertentes dos riachos e córregos e das bordas de capões, onde o relevo é suave e ondulado ou com declividade ligeiramente acentuada. Nestes locais, o lençol freático é superficial e aflora durante o ano todo, e a vegetação formada por um estrato herbáceo denso, muitas vezes atinge $1,5 \mathrm{~m}$ de altura. $\mathrm{O}$ campo limpo úmido também está associado ao campo rupestre, em solos arenosos e litólicos, podendo ser permanentes ou não, de acordo com o nível do lençol freático.

\section{Campo-Sujo}

O campo-sujo é um tipo fisonômico herbáceo-arbustivo, com arbustos e subarbustos esparsos ocorrendo em latossolos profundos, de textura média. No camposujo, freqüentemente, as plantas são representadas por indivíduos das espécies arbóreas do cerrado sentido restrito, cujo porte apresenta-se bem menos desenvolvido.

\section{Campo Rupestre}

O campo rupestre é um tipo fisionômico predominantemente herbáceoarbustivo, com presença eventual de arvoretas pouco desenvolvidas. É facilmente reconhecido por seus afloramentos rochosos com solos rasos e litólicos, ocorrendo em pequenas ou grandes extensões de todas as serras, em altitudes que variam de $1.000 \mathrm{a}$ 1.500 metros. Além disso, possui um mosaico bastante diversificado de ambientes, propiciando uma composição florística rica e com muitas espécies endêmicas. 


\section{Formações Florestais}

\section{Floresta Mesófila}

Trata-se da floresta subperenifólia e situa-se, em geral, sobre terreno plano, em meio à vegetação de cerrado, apresentando continuidade com as matas ciliares. Apresenta elementos comuns aos cerradões, assim como às matas ciliares.

\section{Floresta Alagada (Mata Paludosa)}

Esta formação florestal ocorre apenas sobre solos turfosos com afloramento do lençol freático. É mais comum em terrenos planos, a exemplo das chapadas, ocorrendo em algumas cabeceiras dos córregos. Caracteriza-se pela elevada densidade de árvores.

\section{Matas Ciliares}

Ao longo dos cursos d'água e se estendendo algumas vezes pelas encostas, ocorrem formações florestais com porte que varia de 3 a $15 \mathrm{~m}$, em geral, num gradiente que se eleva das matas de cabeceiras para as do curso inferior dos córregos.

Duas tipologias florestais distintas destas formações ciliares podem ser identificadas na área dependendo do nível de saturação de água do solo. A densidade das árvores destas matas alagadas, normalmente, é bastante elevada e seu porte pode atingir os $20 \mathrm{~m}$ de altura. Estas formações florestais são de grande importância, tanto no que diz respeito à proteção de drenagens, como por fazerem parte diretamente da dinâmica biológica da maioria dos grandes animais da região. Lobos-guará (Chrysocyon brachyurus), suçuaranas (Puma color), tamanduás-bandeira (Myrmecophaga tridactyla), veados (Mazama ssp.), entre outros, encontram abrigo durante o dia nesse ambiente, saindo durante a noite para suas atividades. Outros animais vivem exclusivamente em ambientes florestais, a exemplo do quati (Nasua nasua), macacoprego (Cebus apella), mico (Callithrix penicillata) e jacus (Penelope sp.). O fornecimento de recursos alimentares pelos ambientes florestais é, em geral, elevado, dada a grande presença de árvores produtoras de frutos carnosos.

Em geral, o limite entre a mata e o campo se dá de forma brusca, sem a formação de um ambiente de transição. Em alguns casos, nestas zonas limítrofes podem ser encontrados indivíduos jovens isolados de espécies arbóreas, especialmente do carvoeiro (Sclerolobium paniculatum). Caso sejam mantidas protegidas contra incêndios, estas plantas poderão se desenvolver e adensar, ocasionando a ampliação da área da mata. No entanto, isso ocorrerá em proporções pequenas, devido a restrição edáfica das áreas do entorno. 


\section{Mata de Encosta}

Em função de aspectos edáficos e das espécies predominantes pode apresentar um caráter subperenifólio ou semidecidual e, em geral, apresenta maior perenifolia à medida que se desce a encosta, onde é freqüente apresentar continuidade com a mata ciliar.

\section{Cerradão}

Em geral, o cerradão, encontra-se entre uma formação florestal, em direção a jusante e um cerrado, nas porções mais elevadas do terreno. Compõe-se por diversos elementos comuns aos cerrados, a exemplo do pequi (Caryocar brasiliensis) e o vinhático (Platymenia reticulata) e às florestas, como o carvoeiro (Sclerolobium paniculatum), tendo como espécies típicas, a sucupira-branca (Pterodon emarginatus) e a sucupiras-preta (Bowdichia virgilioides).

\section{Bibliografia}

ICMBIO. Parna da Serra da Canastra. Disponível em: $<$ http://www.icmbio.gov.br/portal/unidadesdeconservacao/biomas-brasileiros>.

SAINT-HILAIRE, A. Viagem às nascentes do Rio São Francisco e pela província de Goiás. Companhia Editora Nacional, 1937. 


\section{APÊNDICE B - ROTEIRO 2}

\section{NAS TRILHAS DE SAINT-HILAIRE: Roteiro 2 1) Formas de vida}

Nesta aula prática cada grupo deverá selecionar e analisar duas áreas distintas, uma próxima à nascente do Rio e outra mais distante da presença da água. Em cada área os alunos deverão analisar quais formas de vida podem encontrar, e assim, realizar uma contagem de quantos espécimes de cada tipo. O método de classificação utilizado será o Sistema de Raunkiær.

Os alunos deverão escolher o tamanho de cada uma das áreas, apresentando uma medida aproximada que considerem relevante para a análise e o porquê da escolha. Todos os dados devem ser registrados nos cadernos de campo.

\section{Classes de formas de vida de Raunkiaer*}

O Sistema de Raunkiær baseia-se no grau de proteção conferido às gemas vegetativas. Quando não há estação desfavorável as gemas da planta encontram-se expostas. Já no caso da estação ser desfavorável à sobrevivência da plantas, as gemas encontram-se mais protegidas.

\section{Classificação das formas de vida segundo Raunkiaer, adaptadas às condições brasileiras}

I - Fanerófitos - plantas lenhosas com gemas aéreas protegidas por catáfilos e situadas acima de $0,25 \mathrm{~m}$ do solo. Apresentam-se com dois aspectos ecoedáficos diferentes: normal climático e raquítico oligotrófico, subdivididos, conforme suas alturas médias, em:

- Macrofanerófitos - plantas de alto porte, variando entre 30 e $50 \mathrm{~m}$ de altura, ocorrendo principalmente na Amazônia e na Região Sul do Brasil;

- Mesofanerófitos - plantas de porte médio, variando entre 20 e $30 \mathrm{~m}$ de altura, ocorrendo na maior parte do território brasileiro;

- Microfanerófitos - plantas de baixo porte, variando entre 5 e $20 \mathrm{~m}$ de altura, ocorrendo principalmente nas Regiões Nordeste e Centro-Oeste; e

- Nanofanerófitos - plantas anãs raquíticas, variando entre 0,25 e $5 \mathrm{~m}$ de altura, com predominância nas áreas campestres do Brasil.

II - Caméfitos - são plantas sublenhosas e/ou herbáceas predominantemente de áreas campestres pantanosas com até um metro de altura, providas de gemas situadas acima do solo e protegidas por catáfilos ou por folhas verticiladas.

III - Hemicriptófitos - plantas herbáceas com gemas protegidas no nível do solo pelos céspedes que morrem na estação climática desfavorável, com predominância em áreas 
campestres.

IV - Geófitos - plantas herbáceas ou sublenhosas com os órgãos de crescimento (gema, xilopódio, rizoma ou bulbo) situados no subsolo, com predominância em áreas campestres.

V - Terófitos - plantas anuais, cujo ciclo vital é completado por sementes que sobrevivem à estação climática desfavorável, ocorrendo exclusivamente nas áreas campestres.

VI - Lianas - plantas lenhosas e/ou herbáceas trepadoras com gemas situadas acima do solo, protegidas ou não por catáfilos, predominantes em áreas florestais.

VII - Xeromórfitos - plantas lenhosas e/ou herbáceas que apresentam duplo modo de sobrevivência ao período desfavorável: um subterrâneo, através de xilopódios, e outro aéreo, com as gemas e brotos de crescimento protegidos por catáfilos. Estas plantas apresentam-se com alturas bastante variáveis, desde $0,25 \mathrm{~m}$ até cerca de $15 \mathrm{~m}$, ocorrendo frequentemente nas áreas savânicas da Região Centro-Oeste brasileira. $\mathrm{O}$ termo "xeromorfo" foi introduzido pela Universidade de São Paulo - USP para designar uma forma vegetal da Savana (Cerrado) de Emas (SP), conforme descrito pelo botânico alemão Felix Kurt Rawitscher $(1942,1944)$.

\section{Chave de classificação das formas de vida segundo Raunkiaer, modificada e adaptada ao Brasil}

Esta chave de classificação apresenta as formas biológicas de Raunkiaer (1934) modificadas, acrescidas das subformas de vida de Ellenberg e Mueller-Dombois (1967) e ainda com mais uma forma de duplo modo de sobrevivência de Rawitscher (1942, 1944), como a seguir:

1 - Plantas autotróficas com um só tipo de proteção do órgão de crescimento................. 2

Plantas autotróficas com dois tipos de proteção dos órgão de crescimento ................ 7

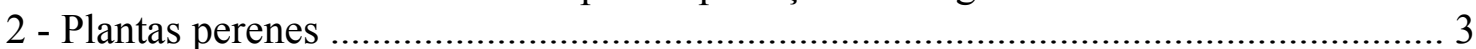

Plantas anuais, reproduzidas através de sementes......................................Terófitos

3 - Plantas lenhosas e/ou herbáceas com órgãos de crescimento protegidos por catáfilos

Plantas sublenhosas e/ou herbáceas com gemas periódicas, protegidas por catafilos e

situadas a até um metro do

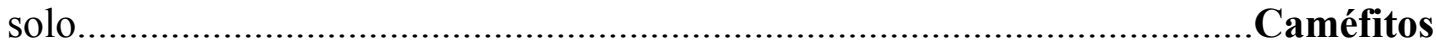

Plantas herbáceas com outros tipos de proteção dos órgãos de crescimento.................5

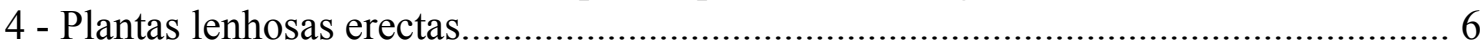

Plantas lenhosas e/ou herbáceas reptantes (cipós)........................................... Lianas

5 - Plantas com gemas situadas no nível do solo, protegidas pela folhagem morta durante o período desfavorável

Hemicriptófitos

Plantas com órgãos de crescimento localizados no subsolo ....................... Geófitos

6 - Plantas cuja altura varia entre 30 e $50 \mathrm{~m}$ Macrofaneróftios

Plantas cuja altura varia entre 20 e $30 \mathrm{~m}$.... Mesofanerófitos

Plantas cuja altura varia entre 5 e $20 \mathrm{~m}$. Microfanerófitos 
Plantas cuja altura varia entre 0,25 e $5 \mathrm{~m}$

Nanofanerófitos

7 - Plantas lenhosas e/ou herbáceas com gemas protegidas por catáfilos na parte aérea e com órgãos regenerativos subterrâneos.

Xeromórfitos

*Texto extraído de IBGE (2012).

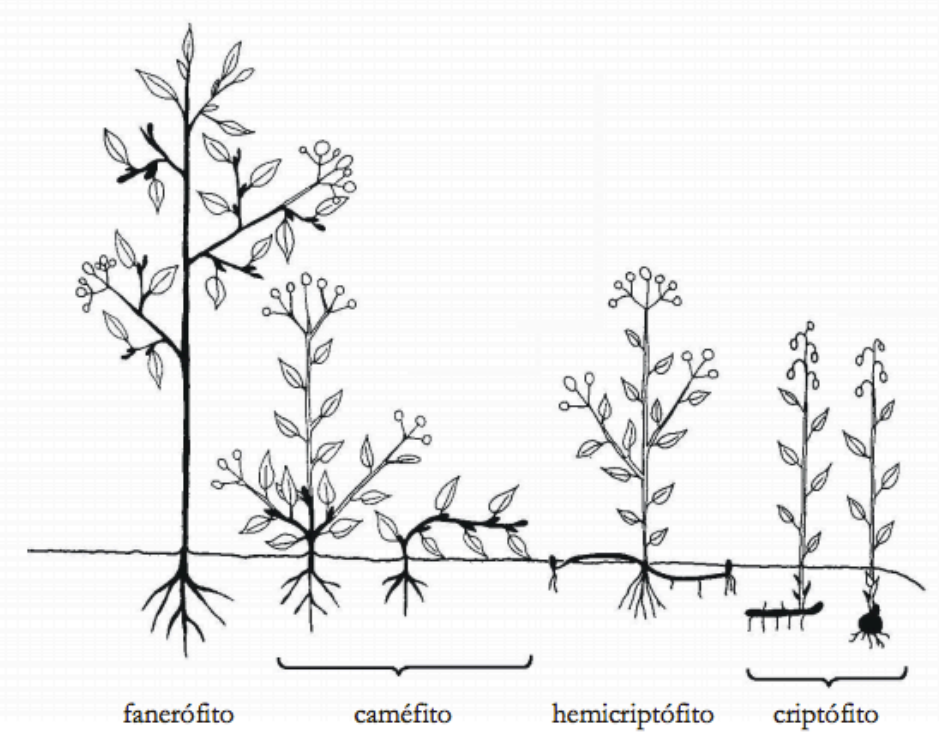

\section{Bibliografia}

IBGE. Instituto Brasileiro de Geografia e Estatística. Manual Técnico da Vegetação Brasileira. 2aed. 271p. 2012.

MARTINS, F. R. \& BATALHA, M. A. Formas de vida, espectro biológico de Raunkiaer e Fisionomia da Vegetação. Apostila digital, Instituto de Biologia, UNICAMP. 2001. Disponível em:

$<$ http://www2.ib.unicamp.br/profs/fsantos/bt682/2003/Apostila-FormasVida-2003.pdf $>$ 
